UNIVERSIDADE DE SÃO PAULO

DEPARTAMENTO DE FILOSOFIA

EVELINE CAMPOS HAUCK

A filosofia política de Adam Ferguson: uma interpretação

São Paulo 

EVELINE CAMPOS HAUCK

\section{A filosofia política de Adam Ferguson: uma interpretação}

Versão Corrigida

Tese apresentada à Faculdade de Filosofia, Letras e Ciências Humana da Universidade de São Paulo.

Área de Concentração: Filosofia

Orientador: Prof. Dr. Pedro Paulo Garrido Pimenta

De acordo:

Prof. Dr. Pedro Paulo Garrido Pimenta 
Autorizo a reprodução e divulgação total ou parcial deste trabalho, por qualquer meio convencional ou eletrônico, para fins de estudo e pesquisa, desde que citada a fonte.

Catalogação na Publicação

Serviço de Biblioteca e Documentação

Faculdade de Filosofia, Letras e Ciências Humanas da Universidade de São Paulo

Hauck, Eveline Campos

A Filosofia Política de Adam Ferguson: uma

interpretação / Eveline Campos Hauck ; orientador

Pedro Paulo Garrido Pimenta. - São Paulo, 2019.

$138 \mathrm{f}$.

Tese (Doutorado) - Faculdade de Filosofia, Letras e Ciências Humanas da Universidade de São Paulo. Departamento de Filosofia. Área de concentração: Filosofia.

1. História da Filosofia Moderna. 2. Iluminismo Escocês. 3. Século XVIII. 4. Filosofia Política. I. Pimenta, Pedro Paulo Garrido, orient. II. Título. 


\section{ENTREGA DO EXEMPLAR CORRIGIDO DA DISSERTAÇÃO/TESE Termo de Ciência e Concordância do (a) orientador (a)}

Nome do (a) aluno (a): _Eveline Campos Hauck

Data da defesa: _30_/_08_/2019

Nome do Prof. (a) orientador (a): _Pedro Paulo Garrido Pimenta

Nos termos da legislação vigente, declaro ESTAR CIENTE do conteúdo deste EXEMPLAR CORRIGIDO elaborado em atenção às sugestões dos membros da comissão Julgadora na sessão de defesa do trabalho, manifestando-me plenamente favorável ao seu encaminhamento e publicação no Portal Digital de Teses da USP.

São Paulo,_09_/_02___2020

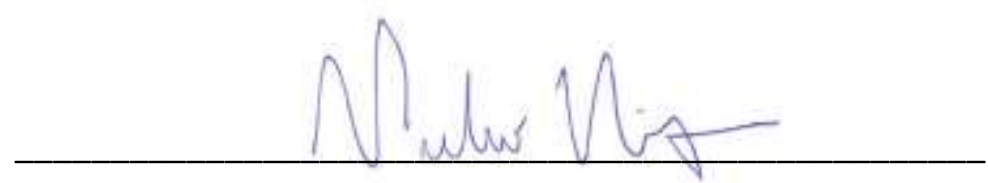

(Assinatura do (a) orientador (a) 
Para a Lúcia e para o Márcio 


\section{Agradecimentos}

Agradeço ao professor Pedro Paulo Pimenta, que aceitou orientar esta tese. E às professoras Isabel Limongi e Yara Frateschi, que participaram da banca de qualificação.

Ao professor Norbert Waszek, que me ajudou com a pesquisa e a bibliografia sobre o Ferguson, além de ter me recebido em Paris.

Aos meus pais, Rosangela e Tadeu, e aos meus irmãos, Francine e Guilherme.

A todos os amigos e colegas que de alguma forma me auxiliaram na elaboração da tese, em especial a Alexandre Amaral, Eder Corbanezi, Júlia Marchevsky, Lara Pimentel e Sonia Boussange.

Aos funcionários do Departamento de Filosofia da USP, principalmente a Geni Ferreira Lima, Luciana Bezerra Nóbrega, Marie Márcia Pedroso e Susan Thiery Satake.

Ao CNPq, pela concessão da bolsa de doutorado. 
Ce n'est pas la Fortune qui domine le Monde. On peut le demander aux Romains, qui eurent une suite continuelle de prosperité quand il se gouvernèrent sur un certain plan, et une suite non interrompue de revers lorqu'ils se conduisirent sur un autre. Il y a des causes générales, soit morales, soit physiques, qui agissent dans chaque monarchie, l'élèvent, la maintennent, ou la précipitent; tous les accidents sont soumis à ces causes, et, si le hazard d'une bataille, c'est-à-dire une cause particulière, a ruiné un Etat, il y avait une cause générale qui faisait que cet Etat devait périr par une seule bataille. En un mot, l'allure principale entraîne avec elle tous les accidents particuliers.

(Montesquieu, Considérations sur les causes de la grandeur des Romains et de leur décadence) 


\title{
Resumo
}

HAUCK, E. C. A filosofia política de Adam Ferguson: uma interpretação. 2019. $138 f$. Tese (Doutorado) - Departamento de Filosofia, Faculdade de Filosofia, Letras e Ciências Humanas, Universidade de São Paulo, São Paulo, 2019.

A tese pretende demonstrar como Adam Ferguson constrói sua filosofia política, sobretudo no Ensaio sobre a História da Sociedade Civil, tendo em vista avaliar o progresso das sociedades comerciais modernas; essa avaliação é feita, particularmente, em termos morais e políticos. Para tanto, o autor faz uma divisão epistemológica entre lei física e lei moral, que o permite, a um só tempo, investigar empiricamente o homem e a sociedade, a partir das influências recebidas de Bacon e Newton, além de seus contemporâneos Hume, Buffon e Smith, e estabelecer uma filosofia moral normativa, próxima à tradição antiga e preocupada com o estabelecimento de regras de conduta para o homem. A filosofia política fergusoniana é expressão desses dois vieses.

Palavras-chave: Filosofia Política; Progresso; Nações Comerciais; Sociedade; Filosofia Moral.

\begin{abstract}
HAUCK, E. C. Adam Ferguson's Political Philosophy: an interpretation. 2019. 138f. Tese (Doutorado) - Departamento de Filosofia, Faculdade de Filosofia, Letras e Ciências Humanas, Universidade de São Paulo, São Paulo, 2019.

The thesis aims to demonstrate how Adam Ferguson builds his political philosophy, especially in the Essay on the History of Civil Society, in order to evaluate the progress of modern commercial societies; this assessment is made, particularly in moral and political terms. In order to do so, the author makes an epistemological division between physical law and moral law, which allows him, at the same time, to investigate empirically man and society, from the influences received from Bacon and Newton, in addition to his contemporaries Hume, Buffon and Smith, and establish a normative moral philosophy, close to the old tradition and concerned with the establishment of rules of conduct for man. Fergusonian political philosophy is an expression of these two biases.
\end{abstract}

Keywords: Political Philosophy; Progress; Commercial Nations; Society; Moral Philosophy. 


\section{Sumário}

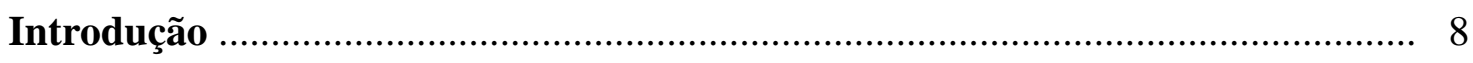

\section{Capítulo I}

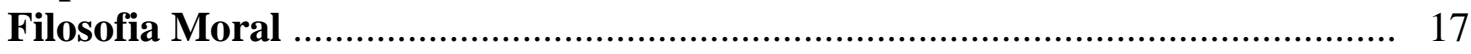

I.i. Pneumática ou história física da mente .................................................. 18

I.ii. Filosofia moral propriamente dita ............................................................... 22

I.iii. A lei de moralidade e suas aplicações .......................................................... 31

I.iv. Da virtude individual para a virtude em sociedade: a nação feliz ..................... 34

\section{Capítulo II}

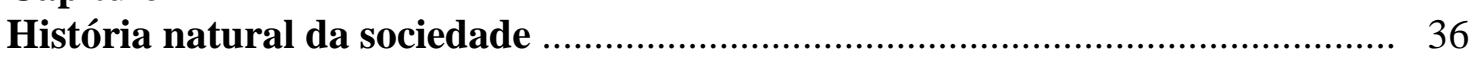

II.i. Dois tipos de história ......................................................................... 37

II.ii. História natural contra história hipotética de Rousseau ................................. 41

II.iii. A questão da fonte ou a história factual ...................................................... 45

II.iv. A história da sociedade como história da espécie ......................................... 49

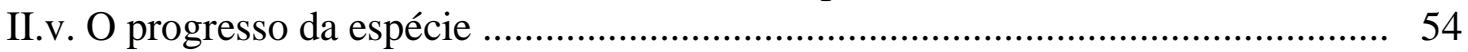

II.vi. Teoria dos estágios: selvagem, bárbaro e polido ........................................ 58

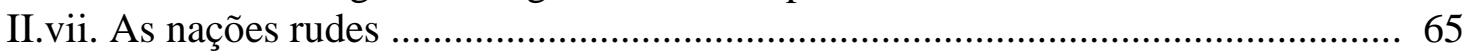

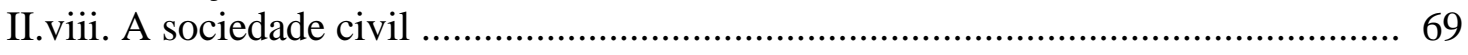

\section{Capítulo III}

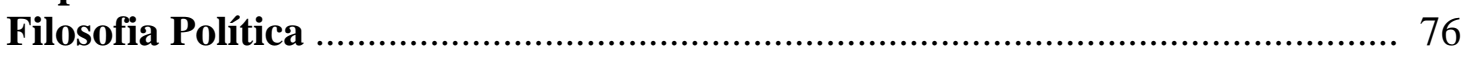

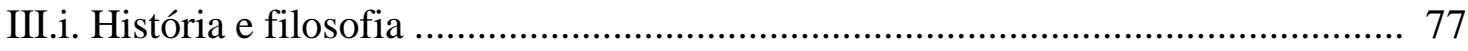

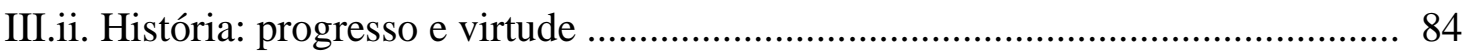

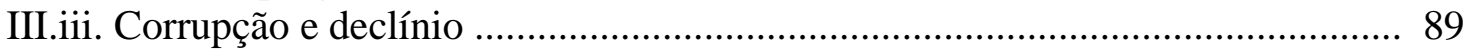

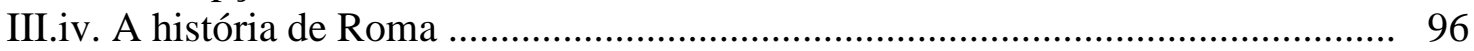

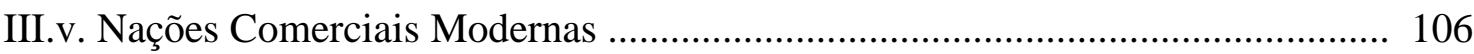

III.v.1. Separação das artes e das profissões .............................................. 106

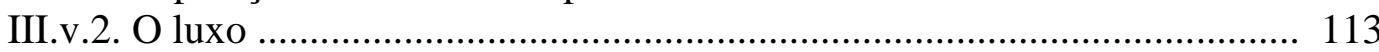

III.v.3. O problema da defesa ............................................................... 119

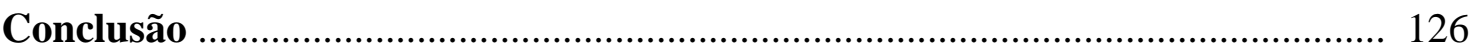

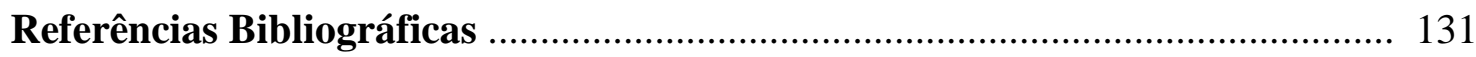




\section{Introdução}

É um lugar comum, dentre os intérpretes de Adam Ferguson (1723-1816), iniciar qualquer estudo sobre o autor apresentando sua biografia. Esse esforço parece ter duas funções. Na maioria dos casos, busca-se não apenas apresentar um autor de modo geral desconhecido, inclusive do público versado na filosofia do século XVIII, como também mostrar sua importância junto ao grupo intelectual do qual fez parte, denominado pelo termo hoje corrente de "Iluminismo Escocês"1. Em casos minoritários, ainda assim relevantes, recorre-se à origem de Ferguson nas Terras Altas (Highlands) da Escócia para tentar explicar sua predileção pelas virtudes marciais, sobretudo a coragem e o heroísmo, em detrimento da moderação e do refinamento, mais ao gosto da intelligentsia das Terras Baixas (Lowlands).

O fato é que Ferguson gozou de muito prestígio no período de sua vida, foi professor na Universidade de Edimburgo - assumindo inicialmente a cadeira de Filosofia Natural, posteriormente a de Pneumática e Filosofia Moral -, publicou diversas obras, que foram traduzidas para vários idiomas e lidas nos círculos intelectuais da Europa; depois, já no século XIX, parece ter perdido esse prestígio, sendo relegado à posição de puzzle em meio a figuras proeminentes como David Hume e Adam Smith.

Talvez por essa razão, a filosofia fergusoniana dá mostras de passar atualmente por um revisionismo crítico²: muitos intérpretes afirmam ser necessário reposicioná-la dentro do debate "antigos versus modernos", mostrando que Ferguson é um contundente advogado da modernidade (ao contrário de pretensas leituras que o viam como um antimoderno ou pessimista histórico), e mitigando o uso que o autor faz de um vocabulário

\footnotetext{
${ }^{1}$ Para um estudo sobre o Iluminismo Escocês, cf. Trevor-Roper, H. The Scottish Enlightenment. In.: Studies on Voltaire and the Eighteenth Century, 58, 1967, pp. 1635-58 e Phillipson, N. The Scottish Enlightenment. In.: The Enlightenment in National Context, org. Roy Porter e Mikulás Teich. Cambridge: Cambridge University Press, 1981.

${ }^{2}$ Iain McDaniel (2013), nas primeiras linhas da introdução de seu Adam Ferguson in the Scottish Enlightenment diz que "Esse é um livro sobre o historiador e pensador político escocês do século XVIII Adam Ferguson. Reavaliando sua contribuição para os debates iluministas sobre as vicissitudes da civilização e o futuro dos Estados prósperos da Europa, seu principal objetivo é fornecer um retrato claro de seu pensamento político e de sua crítica da política moderna" (p. 1). Em um movimento parecido, Craig Smith (2019), também na introdução ao seu Adam Ferguson and the Idea of Civil Society, afirma que "o objetivo do presente estudo é tentar colocar o projeto intelectual de Ferguson de modo geral em seus próprios termos [...]" (p. I).

${ }^{3}$ Esse debate ficou conhecido como a "querela dos antigos e dos modernos". Iniciado nos meios literários e artísticos franceses no final do século XVII, tratava de estabelecer se os autores da antiguidade clássica eram superiores aos da modernidade. Essa querela se estendeu também à Grã-Bretanha, ficando conhecida, na ilha, por "a batalha dos livros", em referência a uma sátira escrita por Jonathan Swift, em 1707, chamada "The Battle of Books", que fora incluída como prolegômenos ao seu A Tale of a Tub.
} 
da tradição antiga, com noções de virtude e corrupção. Com efeito, acreditamos igualmente que Ferguson não foi partidário dos "antigos", mas não compartilhamos das posições que pretendem ignorar suas considerações sobre o papel da virtude para a felicidade nacional. Ora, Ferguson tem uma crítica particular acerca das sociedades modernas, que embora dialogue diretamente com seus contemporâneos, apresenta uma posição muito original sobre o comércio, cujo avanço parece criar um "paradoxo do progresso e do declínio" (Waszek, 2014, p. 58).

Dessa forma, podemos afirmar que a filosofia de Ferguson está inserida no debate, caro ao século XVIII, sobre o desenvolvimento do comércio e suas consequências tanto econômicas quanto políticas para os Estados modernos, em especial para a Inglaterra e para a França. Istvan Hont (1983), em um estudo consagrado sobre a economia política do período, colocou o debate em termos de "riqueza" e "virtude". Smith, figura central do debate para o estudioso inglês, teria questionado, principalmente em A Riqueza das Nações (1776), as sociedades comerciais por produzir uma enorme riqueza (luxo) e ao mesmo tempo uma enorme desigualdade. Em linhas muito gerais, para Smith, esse paradoxo, ainda que insolúvel, daria razão à modernidade: equacionando os termos, percebemos que a grande riqueza produzida termina por ser distribuída, embora muito parcialmente, para os mais pobres, que a partir de seu trabalho conseguem suprir suas necessidades mais básicas muito melhor do que os homens em qualquer outro estágio do progresso da sociedade. Nas sociedades primitivas, a igualdade só podia ser concebida como "igualdade de pobreza", enquanto nas sociedades comerciais, a desigualdade da riqueza poderia gratificar até mesmo os estratos mais pobres (Hont, 1983, p. 3).

Além do problema da justiça, Smith discute também o papel do comércio na promoção da liberdade; segundo ele, foi Hume quem primeiro fez tal observação: "Hume foi 'o único escritor que, até onde sei, já tomou conhecimento' do modo no qual 'o comércio e as manufaturas gradualmente introduzem ordem e bom governo, e com eles, liberdade e segurança aos indivíduos, os quais anteriormente teriam praticamente vivido em um estado de guerra com seus vizinhos e de dependência servil dos seus superiores"” (Winch, 1979, p. 72). Quer dizer, embora Smith não possa ser considerado um otimista irrestrito $^{4}$ quanto ao progresso social, é evidente sua visão positiva da maneira como o comércio e a riqueza contribuíram para o aperfeiçoamento geral das nações modernas.

Porém, antes de Smith, foi Rousseau quem apresentou o problema da riqueza e da virtude nas sociedades comerciais modernas. No Discurso sobre a origem e os

\footnotetext{
${ }^{4}$ Donald Winch (1979) critica aqueles que rotulam Smith de "celebrante otimista do progresso social" (p. 71).
} 
fundamentos da desigualdade entre os homens (1754), o genebrino analisa de que forma o progresso social produziu uma enorme desigualdade moral ou política. Essa desigualdade está amparada em outras desigualdades decorrentes do surgimento da sociedade e da propriedade privada: "da extrema desigualdade das condições e das fortunas, da diversidade das paixões e dos talentos, das artes inúteis, das artes perniciosas, das ciências frívolas, sairiam multidões de preconceitos, igualmente contrários à razão, à felicidade e à virtude" (Rousseau, p. 2002, p. 239). Ora, Rousseau mostra, diferentemente do que Smith veio a escrever anos depois, que a igualdade e a simplicidade das sociedades primitivas eram muito mais favoráveis à virtude e à felicidade do gênero humano do que os Estados comerciais da modernidade.

Ferguson, no Um Ensaio sobre a História da Sociedade Civil (1767), toma parte no debate, rejeitando as duas posições apresentadas anteriormente. Para ele, a desigualdade não constitui um problema para os Estados modernos, já que a distinção, mesmo de propriedade, é desejável nas monarquias. Na verdade, a questão central para Ferguson é como a divisão do trabalho, surgida com o comércio e responsável pela grande produção de riqueza na modernidade, pode engendrar um problema moral e político, ou seja, pode ser responsável pela corrupção e pelo declínio das nações. O fato é que a divisão das profissões alcança os departamentos da política e da guerra, criando cargos meramente burocráticos para funções que devem ser exercidas por cidadãos preocupados em defender, por si mesmos, sua liberdade e a de seu país.

Há uma passagem na edição de 1773 do Ensaio, em que Ferguson menciona diretamente a filosofia de Adam Smith e parece apontar para a futura publicação de $A$ Riqueza. Ali, Ferguson diz que "especulações sobre o comércio e a riqueza foram realizadas pelos mais talentosos autores, e em breve o público terá à disposição uma teoria da economia nacional que nada ficará a dever a qualquer outra teoria científica consagrada" (Ferguson, 2019, p. 210) , acrescentando uma nota com referência à Teoria dos Sentimentos Morais. O mais importante vem em seguida: "Visto que os homens, a exemplo de outros animais, vivem em multidões em que as necessidades da vida são acumuladas e as reservas de riqueza, ampliadas, tais situações nos levam a desconsiderar a felicidade e o caráter moral e político de um povo; e, ansiosos em propagarmos o rebanho, não vemos além do rancho e do pasto. Esquecemo-nos de quantas vezes uns poucos trataram muitos como presas; que, para os pobres, nada é tão tentador quanto os

\footnotetext{
${ }^{5}$ Usaremos em todo a tese a tradução de Pedro Paulo Pimenta (2019) do Ensaio sobre a história da sociedade civil. No mesmo volume, há ainda a tradução das Instituições de Filosofia Moral, de Eveline Campos Hauck. No prelo, pela editora UNESP. Todas as citações se referem ao Ensaio, salvo menção explícita às Instituições.
} 
cofres dos ricos; e, quando o preço pela liberdade é pago, o peso da espada do vitorioso pode cair sobre o vencido" (Ferguson, 2019, p. 211). Dessa forma, Ferguson faz notar que os recursos nacionais não se resumem à riqueza ${ }^{6}$, ainda que pondere sobre sua relevância; muito ao contrário, a seu ver, "o caráter moral e político de um povo" deve ser considerado como a questão principal da felicidade nacional.

Assim, se lermos o Ensaio na perspectiva do debate sobre a riqueza e a virtude no progresso da sociedade, não há como negar a inclinação de Ferguson pelo tema da virtude, posicionando-se mesmo como complementar às discussões de Smith na Riqueza. Nesse sentido, o autor estaria ainda comprometido com as formas tradicionais de se pensar a política, sobretudo com o humanismo cívico ${ }^{7}$, ao contrário da discussão "moderna", baseada na economia política, empreendida por Smith - mas também por Hume -, para quem "as sociedades deveriam ser comparadas com base na segurança com que fundamentaram os direitos de propriedade e na adequação com que satisfizeram as necessidades de seus trabalhadores"8. No entanto, Ferguson está muito longe do discurso rousseauísta de censura ao progresso social, ao comércio e ao luxo, em prol do modo de vida rústico dos povos primitivos ou do modelo republicano das nações da antiguidade.

Pretendemos demonstrar, portanto, como Ferguson constrói sua filosofia política, no Ensaio, tendo em vista avaliar o progresso das sociedades comerciais modernas; e essa avaliação é feita, sobretudo, em termos morais e políticos. Como afirma David Kettler (1965), “o pensamento de Ferguson sobre a sociedade só pode ser completamente compreendido à luz da sua concepção de virtude” (p. 187). Ademais, há ainda que se considerar, como o próprio Kettler indica, a separação que Ferguson faz entre, no que concerne às leis da natureza humana, lei física e lei moral; nos Princípios de Ciência Moral e Política (1792), lemos que "uma lei física da natureza é uma expressão geral do que é uniforme ou comum na ordem das coisas e é endereçada aos poderes da percepção e da sagacidade. Uma lei moral da natureza é igualmente geral, porém uma expressão não de um fato, mas do que é bom, e é endereçada aos poderes da estima e da escolha" (Ferguson, vol. I, p. 159). Ora, esse desdobramento epistemológico permite ao autor, a

\footnotetext{
${ }^{6}$ Embora Ferguson demonstre grande estima pelo trabalho de economia de Smith, ele parece querer reduzilo a um tratado sobre a riqueza, sem levar em conta as discussões do autor sobre a moral e a política.

${ }^{7}$ Entendemos o humanismo cívico, ou simplesmente tradição cívica, no sentido que Pocock (1975) dá a ele: "a combinação do pensamento aristotélico e maquiaveliano a respeito do zoon politikon" (p. 462).

8 “O compromisso central do discurso cívico [...] era com a 'virtude', com o ativismo político da elite proprietária, enquanto o comprometimento de Hume e Smith era com a justiça. No discurso cívico, as sociedades da Europa foram comparadas a partir de suas formas de governo e do grau de liberdade política que concediam para a nação política. $\mathrm{Na}$ análise smithiana e humiana, as sociedades deveriam ser comparadas com base na segurança com que fundamentaram os direitos de propriedade e na adequação com que satisfizeram as necessidades de seus trabalhadores" (Hont, 1983, pp.6-7).
} 
um só tempo, investigar empiricamente o homem e a sociedade, a partir das influências recebidas de Bacon e Newton, além de seus contemporâneos Hume, Buffon e Smith, e estabelecer uma filosofia moral normativa, próxima à tradição antiga e preocupada com o estabelecimento de regras de conduta para o homem. "Essa dupla perspectiva", segundo Norbert Waszek (2003), "é de fato necessária se quisermos fazer justiça à obra de Ferguson no seu conjunto"9.

Nossa tese abordará, dessa maneira, a filosofia política fergusoniana como expressão desses dois vieses. Para tanto, analisaremos, em primeiro lugar, a filosofia moral do autor, mostrando sua inspiração na tradição estoico-ciceroniana, com uma concepção de virtude que exclui os objetos externos, como a riqueza, nas suas considerações sobre a felicidade. Mais ainda, Ferguson considera como virtude principal (além das virtudes apontadas pela tradição clássica) a probidade, benevolência ou amor ao gênero humano; quer dizer, trata-se de uma virtude que aponta para uma existência em comum com outros homens, uma vida política. Em um segundo momento, dedicar-nosemos à investigação que Ferguson faz sobre a sociedade, através da elaboração de uma história natural da sociedade civil. Essa é a história do progresso da sociedade (tomada em sentido indiciário), que acomoda uma teoria dos estágios de seu desenvolvimento, desde os primórdios rudes, com os selvagens, até as formas mais polidas, a sociedade civil propriamente dita. Por fim, abordaremos a filosofia política, a qual consideramos uma espécie de síntese dos dois momentos anteriores, pois trata do progresso e do declínio das nações, tendo em vista a investigação da sociedade e uma concepção de declínio baseada na corrupção moral dos indivíduos.

Essa divisão da nossa tese em três partes reflete, propositadamente, o movimento característico do Ensaio, obra principal de Ferguson e basilar de sua ciência política. Nossa inclinação para o Ensaio não significa excluir os demais trabalhos do autor, ao contrário, abordaremos a obra de Ferguson como um todo na medida em que auxiliar e complementar nossa compreensão de seus argumentos e de sua filosofia de modo mais abrangente. Discordamos, com isso, da posição de Craig Smith (2019), para quem a predominância de uma visão do autor a partir da leitura do Ensaio causou "um impacto

\footnotetext{
9 “Como já havia escrito Kames, um contemporâneo de Ferguson, a partir da publicação do Ensaio sobre a história da sociedade civil, essa obra tem a perspectiva de retraçar a história e o desenvolvimento da sociedade, mas também, ao mesmo tempo, de desviar os homens de seu egoísmo e de 'restaurar essas paixões viris que são o heroísmo, a generosidade, e o amor de nossa espécie'. Essa dupla perspectiva é, de fato, necessária se quisermos fazer justiça à obra de Ferguson no seu conjunto" (Waszek, 2003, pp. 61-62).
} 
infeliz quando puseram em foco alguns aspectos do pensamento de Ferguson que apareceram ali, mas são menos significativos em outros de seus escritos". Um desses aspectos, ainda segundo Smith, seria o "eixo traçado na riqueza e na virtude", dando "a impressão de que há tensões significativas entre os dois em sua obra e que seu projeto como um todo seria o de favorecer a virtude antiga sobre o comércio moderno" (p. 3). Ora, tal concepção dicotômica, quase maniqueísta, exclui de partida a possibilidade de considerar que Ferguson usou a noção de virtude antiga apenas como chave de leitura da modernidade, sem, com isso, posicionar-se favoravelmente a este ou aquele período. No nosso entendimento, o autor se favoreceu de variadas tradições e influências, seja do passado, como no caso das tradições estoico-ciceroniana, cívica e republicana, seja da modernidade, sob a influência, por exemplo, de Montesquieu, Hume e Smith, alinhandose a cada uma delas apenas parcialmente e na medida de seu interesse. Nesse sentido, procuramos fazer, ao longo de nosso trabalho, diversas relações entre o pensamento de Ferguson e de muitos outros autores, ora para mostrar como a filosofia do autor estava inserida nos principais debates de sua época, ora para apontar possíveis fontes.

Como diz Duncan Forbes, “influências são fenômenos estranhos e complexos" ${ }^{\prime 10}$. Não por acaso, esse tema é objeto de muita controvérsia entre os intérpretes da filosofia fergusoniana. Alguns comentadores, por exemplo, David Ketller (1965), Lisa Hill (2006) e Eugene Heath (2009) veem na concepção de virtude política de Ferguson, sobretudo seu aspecto cívico e ativo, uma derivação do estoicismo mais tardio, ou romano. Principalmente Heath e Hill enfatizam o papel de Cícero na organização e divulgação do pensamento estoico e sua influência sobre Ferguson. Outros, a começar por J. G. Pocock, viram na concepção de virtude de Ferguson, principalmente pelo modo como foi trabalhada no Ensaio em termos de espírito nacional, uma clara referência à virtù de Maquiavel. Em seu extenso livro de 1975, The Machiavellian Moment, Pocock afirma que "o Ensaio sobre a História da Sociedade Civil de Adam Ferguson é talvez a investigação escocesa mais maquiaveliana sobre o tema” (p. 499), referindo-se ao emprego da "linguagem da virtude e corrupção", ou seja, "da linguagem do humanismo cívico" (p. 498). Duncan Forbes (1966), depois dele, reitera a influência de Maquiavel quando diz que "qua um moralista maquiaveliano, Ferguson estava preocupado com a virtù de homens e nações, com espírito público e vigor nacional, com a falta deles, ou seja, com a corrupção, e com as formas e graus de corrupção em diferentes tipos de Estado e diferentes condições sociais" (p. xxviii). Por fim, há ainda aqueles que reivindicam a

\footnotetext{
${ }^{10}$ Prefácio de Duncan Forbes ao The Scottish Enlightenment and Hegel's account of 'Civil Society', de Norbert Waszek (1988), p. xii.
} 
filosofia fergusoniana no rol da tradição republicana. Marco Geuna (2002), para citar apenas um exemplo, afirma que "não há dúvida que seu pensamento [de Ferguson], especialmente em seu trabalho mais importante, o Ensaio sobre a história da sociedade civil, é caracterizado por um emprego sistemático de categorias pertencentes à tradição republicana de pensamento" (p. 181).

Não há como negar a influência de Cícero sobre o pensamento moral e político de Ferguson, não só porque o autor o cita várias vezes ao longo de sua obra, mas igualmente porque o filósofo e orador romano, em seus textos de viés estoico, mitiga o caráter passivo da virtude, que pode ser encontrado principalmente no estoicismo grego, destacando seu âmbito político e ativo. No que concerne ao humanismo cívico e sobretudo a Maquiavel, é difícil determinar seu grau de influência. Há apenas uma única citação de Maquiavel na obra do autor, mais precisamente na História do Progresso e Ruína da República Romana (1783), ainda que seu vocabulário do ativismo cívico e das razões para a formação de milícias sejam muito próximas às do Florentino e da tradição ao qual seu pensamento está inserido ${ }^{11}$.

É possível falar em republicanismo em Ferguson apenas na medida em que é um “discurso intelectual sobre a política" (muito próximo da tradição cívica) e não uma "causa política prática"12, pois o autor não somente não atuava na defesa da república como forma de governo, como considerava a monarquia uma forma legítima e não corrompida. Entretanto, é verdade que Ferguson, ainda que avalize a teoria das formas de governo de Montesquieu, sobrepõe princípios da república à monarquia. É o caso de sua defesa de uma preeminência baseada sobretudo em talentos e virtudes pessoais (não

\footnotetext{
${ }^{11}$ Lisa Hill (2006), nesse mesmo sentido, afirma que "parece haver também muito de Maquiavel na filosofia de Ferguson e os estudiosos tendem a tomar por certo sua influência apesar da recusa mais ou menos completa de Ferguson em citá-lo, para não falar no simples reconhecimento de sua existência. O pensamento de Maquiavel deve ter chegado a Ferguson indiretamente. James Harrington popularizou o pensamento de Maquiavel e o trouxe para a atenção pública no século dezessete. Mandeville (com quem Ferguson gasta muita energia) também transmitiu o pensamento de Maquiavel para público britânico, enquanto Montesquieu (quem, afirma-se, tomou muita coisa de Maquiavel sem o devido reconhecimento) é uma outra possível fonte. Mas é também possível que muita da influência atribuída a Maquiavel venha do mesmo lugar que Maquiavel a encontrou, ou seja, de Tácito, de Cícero e de outras autoridades clássicas" (p. 39).

${ }^{12}$ Segundo John Robertson (1985), "tanto os humanistas quanto Maquiavel do Discorsi foram ardentes defensores da forma de governo republicana contra a principesca; e esse comprometimento poderia bem ser expresso em princípios constitucionais cívicos. Foi sempre difícil conceber, em termos cívicos, como um único governante poderia ser impedido de se tornar arbitrário e despótico, dependendo, para sua segurança, de soldados mercenários. Ainda assim, republicanismo e tradição cívica não devem simplesmente ser tomados como sinônimos. O republicanismo foi uma causa política prática, em nenhum sentido dependente exclusivamente da tradição cívica para seu suporte intelectual. [...] A tradição cívica, por outro lado, foi um discurso intelectual sobre a política; e, em seus termos, não foi totalmente impossível - como Aristóteles havia indicado - considerar a monarquia como uma forma constitucional de governo, ou conceber - como o fez Maquiavel no Il Principe - um príncipe usando uma milícia para ganhar a obediência de seus súditos-cidadãos" (p. 11).
} 
exclusivamente em nascimento, título e propriedade, como é típico numa monarquia). Mas é principalmente a consideração negativa que nosso autor tem da moderação, como uma espécie de virtude das monarquias, que o coloca mais próximo da tradição republicana. Para Montesquieu e para Hume, principalmente nas monarquias modernas, o comércio engendra um espírito de moderação salutar para as maneiras e para as instituições, pois garante a estabilidade política necessária para a paz e a justiça e proporciona novas formas de relacionamento entre os indivíduos. Ferguson, ao contrário, acreditava que a estabilidade das instituições e a justiça doméstica seriam alcançadas através do espírito vigilante e vigoroso dos membros de uma comunidade. Segundo ele, "afinal, o mérito de um homem é inteiramente determinado por sua candura e generosidade em relação a seus associados, por seu zelo por objetivos nacionais e por seu vigor na manutenção dos direitos políticos - não pela simples moderação, que com frequência procede da indiferença ao interesse nacional e público e relaxa os nervos dos quais depende a força do caráter público e também do privado" (Ferguson, 2019, p. 278).

Nós defendemos, como David Winch (1978) e Iain McDaniel (2013), que o pensamento político de Ferguson é devedor, acima de tudo, de Montesquieu ${ }^{13}$, e que, muito provavelmente, deve ter sido através dele que nosso autor tomou conhecimento de Maquiavel. Uma ideia de como a corrupção pode provocar a decadência de uma nação pode ser encontrado nas Considerações sobre as causas da grandeza dos romanos e de sua decadência (1734). Ainda, de acordo com Winch, Montesquieu, "com a publicação de $O$ Espírito das Leis em 1748", não apenas "suplantou e modernizou o papel previamente ocupado por Maquiavel como o representante principal da abordagem empírica da investigação política" (Winch, 1979, p. 36), como também "pode ser visto como o último grande expoente de uma tradição clássico-renascentista de preocupação com o cultivo de qualidades políticas distintivas" (Winch, 1979, p. 37). Esse papel de Montesquieu como uma figura de transição pode ser facilmente reconhecido em Ferguson.

Porém, Ferguson, ao contrário do filósofo francês, não abriu mão da noção de virtude para acomodar "uma base para um novo plano de liberdade" (Winch, 1979, p. 37). Nosso autor desconfiou da capacidade do comércio em promover a liberdade política e advogou a favor da participação ativa dos cidadãos para a manutenção da liberdade e da estabilidade das nações, mesmo em um sistema político como o da Inglaterra, em que

\footnotetext{
${ }^{13}$ É interessante notar que Ferguson parece ter visto Montesquieu como "um tipo de moralista estoico, associando seus escritos com aqueles de Shaftesbury, Francis Hutcheson e James Harris" (McDaniel, 2013, p. 12). Nos Princípios, Ferguson perfila Montesquieu ao lado desses moralistas para dizer que o espírito da filosofia estoica permanece mesmo nos tempos modernos (Ferguson, 1792, vol. I, p. 8).
} 
as instituições, segundo ele, eram as mais sábias. Ora, Ferguson parece ter unido uma concepção de virtude cívica e de ativismo da tradição estoico-ciceroniana à teoria das formas de governo de Montesquieu para desenvolver uma teoria política própria, posicionando-se assim criticamente em relação a seus pares intelectuais, como Hume e Smith, que fizeram das considerações sobre o comércio e sobre as instituições as bases para a economia política nascente. As diferenças e aproximações entre Ferguson e seus interlocutores mais diretos serão pontuadas no decorrer deste trabalho. 


\section{Capítulo I}

\section{Filosofia Moral}

Há na filosofia de Ferguson uma divisão entre lei física e lei moral, aquela se referindo aos fatos, e esta, ao que é obrigatório (Ferguson, Instituições, 2019, p. 385). Dessa separação, resultam, no que concerne à investigação sobre o homem, a pneumática e a filosofia moral: aquela "trata fisicamente da mente ou do espírito. Essa ciência consiste de duas partes. A primeira trata do homem; a segunda, de Deus. A parte que trata do homem pode conter a história da natureza do homem e uma explicação ou teoria dos principais fenômenos da vida humana"; a outra é "o conhecimento daquilo que deve ser, ou a aplicação de regras que devem determinar a escolha de agentes voluntários" (Ferguson, Instituições, 2019, p. 388).

Quando se aborda a filosofia moral de Ferguson como um todo, é comum vermos esses dois aspectos conjugados, como se não houvesse, no pensamento do autor, uma separação nítida e clara de uma e outra parte. Contudo, a parte física, que se refere aos fenômenos morais empiricamente observados, é a pneumática, e a filosofia moral propriamente dita, diz respeito aos deveres morais, regras para a conduta de seres inteligentes, capazes de escolha. Assim, no que se refere à moralidade, temos o seguinte desdobramento: o que ocorre de fato ("O que os homens, na maioria dos casos, aprovam ou censuram?/ Por qual princípio, ou consideração, eles são direcionados, em casos particulares, a conferir suas aprovações e censuras?") está compreendido no estudo da mente humana, e o que ocorre a partir de princípios e objetos morais ("Qual é o objeto próprio da aprovação e da censura?/ Qual é a regra ou princípio pelo qual os homens devem julgar os caracteres morais?” (Ferguson, Instituições, 2019, p. 448)) está compreendido na filosofia moral.

Ainda que haja essa separação, que é mais uma exigência metodológica que prática, a compreensão da filosofia moral depende de uma análise empírica da natureza do homem, ou seja, da pneumática, que é justamente a sua fundação:

Antes de podermos determinar regras de moralidade que se ajustem a qualquer natureza particular, o fato relacionado àquela natureza deve ser conhecido. Antes de podermos determinar regras de moralidade para o gênero humano, a história da natureza do homem, suas disposições, suas alegrias e sofrimentos específicos, suas condições e perspectivas 
futuras, devem ser conhecidas. A pneumática, ou a história física da mente, é a fundação da filosofia moral (Ferguson, Instituições, 2019, p. 388).

\section{I.i. Pneumática ou história física da mente}

Ferguson concebe a existência de uma ordem na natureza, de inspiração estoica $^{14}$, que garante uma posição para cada coisa, uma escala dos seres que inclui desde a matéria mais ínfima até o ser humano, desde o mais simples ao mais complexo. Essa ordenação é expressão de um logos universal (de uma providência divina, muitas vezes concebida, na tradição estoica, como imanente à natureza) e pode ser observada através de diversas subdivisões, que demonstram não só uma perfeição, como também "uma economia específica e uma relação, verificando, em cada espécie ou classe de ser, a predileção da natureza por combinação e subserviência mútua nos membros dos quais a classe é composta" (Ferguson, 1792, vol. I, p. 19).

Assim, considerando essa ordenação na natureza, há uma divisão entre as coisas vivas e não vivas, que são os seres ou matéria, respectivamente. É própria dos seres vivos a atividade e da matéria, a inércia. No que concerne aos seres vivos, podemos subdividilos em vegetais e animais, sendo a vontade (nos animais, a vontade é apenas "mudança voluntária de lugar", que não pode ser confundida com a vontade livre dos homens), a sensibilidade (“capacidade de prazer e sofrimento") e o "propósito de ação" (Ferguson, 1792, vol. I, p. 14) as principais características dos animais e que os distinguem dos vegetais. Há ainda outra divisão: "entre as variedades do reino animal, alguns são considerados associativos ou gregários, outros solitários" (Ferguson, 1792, vol. I, p. 18). No reino animal, alguns seres só se conectam uns aos outros ocasionalmente, devido à “disposição mútua dos sexos” (Ferguson, 1792, vol. I, p. 20), são os animais solitários; outros são observados sempre em bandos, seja simplesmente para pastar ou voar conjuntamente, os animais meramente gregários ou associativos, seja trabalhando "para um propósito comum” (Ferguson, 1792, vol. I, p. 21), os animais ditos gregários ou políticos. Os homens são um exemplo típico desses últimos, e a sociedade, nome do agrupamento humano (como há outros coletivos apropriados a outros animais, por

\footnotetext{
${ }^{14}$ Segundo Muller (2006), para os estoicos, “a terra, dividida em cinco zonas, é também o lugar de uma hierarquia digna de atenção. Os seres que contém são, com efeito, ordenados em quatro gêneros, em função da qualidade de seu pneuma. A cosmogonia nos deu há pouco uma visão geral: há, primeiro, os seres inanimados, cuja unidade é assegurada por seu 'estado'; depois, as plantas, com as quais a pneuma toma a forma da 'natureza' no sentido estrito; em seguida temos os animais, seres animados no sentido próprio porque são dotados de uma alma; e, por fim, os seres racionais, que têm o privilégio do logos” (p. 86).
} 
exemplo, rebanho, cardume, enxame etc.) está para a espécie humana da mesma forma que o enxame está para a espécie das abelhas. Nesse momento de sua argumentação, Ferguson afirma que "estar em sociedade é o estado físico da espécie” (Ferguson, 1792, vol. I, p. 24) ${ }^{15}$; porém, a sociedade humana não se resume apenas aos traços de sua natureza animal, mas esse detalhamento pressupõe uma filosofia moral, que ainda será tematizada.

A sociedade, enquanto característica da espécie, não se configura como ponto de distinção dos homens em relação aos demais animais. Esse ponto, ou o princípio que os diferencia, é sua "inteligência ou mente":

Porém, há um princípio, em respeito do qual o homem se diferencia dos outros animais, não apenas em medida ou grau, mas totalmente e em tipo. A esse princípio chamamos sua inteligência ou mente, intimamente consciente de si, enquanto se manifesta em pensamento, discernimento e vontade (Ferguson, 1792, vol. I, p. 48).

Os homens, portanto, estão excluídos desse sistema que ordena os demais seres da natureza; sua diferença em relação a eles não é somente quantitativa, mas também qualitativa ${ }^{16}$. Para nosso autor, os seres são divididos em vida vegetal e animal e vida inteligente, separando-se, dessa forma, os homens dos demais seres. Claro que há no homem características semelhantes às dos animais, justamente porque sua espécie tem uma característica animal; porém, os homens, como seres inteligentes, têm ainda leis particulares, que para Ferguson estão reunidas na Teoria da mente ${ }^{17}$, e que põe a humanidade acima da animalidade pura e simples. As leis da mente são, tais como as leis do sistema material, "leis físicas, coligidas de fatos e são aplicadas a fim de explicar aparências" (Ferguson, Instituições, 2019, p. 429). A comparação com o sistema material

\footnotetext{
${ }^{15}$ No Ensaio, lemos: “'O homem nasce em sociedade', diz Montesquieu, 'e nela permanece'. Os encantos que o incitam a tal são muitos, como se sabe. Além do afeto dos progenitores, que em vez de abandonar os adultos, como acontece entre as feras, torna-se mais forte, misturando-se com a estima e a memória de seus primeiros efeitos, pode-se contar a propensão comum ao homem e aos outros animais de se misturar à horda, e, irrefletidamente, acompanhar a multidão da espécie" (Ferguson, 2019, p. 46).

${ }^{16}$ Essa noção tem uma dupla origem. Para os estoicos, os homens, por serem dotados de inteligência, diferenciam-se fundamentalmente dos demais seres naturais. Para Buffon, os seres humanos são dotados de uma característica material, que os inclui no reino animal, e de uma característica intelectual, que os faz totalmente diferentes de qualquer outro ser; é justamente o pensamento e a capacidade de expressá-lo, através da linguagem, que separa a humanidade da animalidade. Assim, a história do indivíduo será composta por seus aspectos interiores e exteriores, intelectual e material. O homem interior, por causa de sua alma, é dotado da capacidade de pensar, poder que o torna capaz de perfectibilidade. Os demais animais, ao contrário, não são capazes de inventar nem de aperfeiçoar nada, ou seja, não são capazes de qualquer "espécie de progresso" (Buffon, 1971, p. 45).

${ }^{17}$ A Teoria da mente é parte constitutiva da pneumática, por isso diz respeito às leis físicas da mente humana.
} 
é importante pois o sistema científico perfeito pode ser encontrado em Newton ${ }^{18}$, e a lei de gravitação é o principal modelo das ciências naturais a ser aplicado à ciência do homem: o sistema intelectual tem leis próprias da mesma forma que o material. Mais ainda, como nas ciências naturais, há leis que são fatos últimos, o que quer dizer que não podem ser esclarecidas, já que são o próprio limite explicativo de um fenômeno ${ }^{19}$.

$\mathrm{Na}$ Teoria da mente, há as leis físicas do entendimento e da vontade ${ }^{20}$; aquelas são a percepção e a compreensão, estas são a lei de autopreservação, a lei de sociedade e a lei de apreciação (law of estimation) ${ }^{21}$. É interessante notar que Ferguson reconhece que, nos homens, a inteligência, não apenas os torna capazes de conhecimento (através do entendimento), mas igualmente de escolha (através da vontade). Das leis da vontade, tanto a lei de autopreservação quanto a de sociedade estão presentes também nos animais; própria apenas aos homens é a lei de apreciação. Ademais, como nos lembra Victor Cousin em um estudo clássico (1840), as duas primeiras não "exprimem um fim, mas um meio", tanto a conservação quanto a sociabilidade são meios para se alcançar uma finalidade propriamente humana, a saber, a excelência ${ }^{22}$. É dessa possibilidade de excelência (moral) expressa pela lei de apreciação ou desejo de destaque ${ }^{23}$ que nosso autor deriva o princípio da aprovação moral:

\footnotetext{
18 "Houve pouco progresso no conhecimento, enquanto homens de inventividade supuseram que a ciência consistisse na explicação de fatos primários, os quais a natureza nos deu para o uso, não para a teoria: tais são, no sistema material da natureza, as leis de gravitação e movimento. Foi em vão tentar explicá-las; porém, assim que foram consideradas fundamentais na natureza, não no que diz respeito à sua origem, mas no que diz respeito à suas aplicações e consequências, a ciência progrediu rapidamente na explicação do fenômeno do sistema no qual elas vigoram" (Ferguson, 1796, vol. I, p. 76).

19 "Todos os fatos, que não podem ser explicados por uma regra previamente conhecida, ou mais bem conhecida que os fatos mesmos, podem ser denominados fatos últimos" (Ferguson, Instituições, 2019, p. 387 , grifo do autor).

${ }^{20}$ Essas leis da vontade coincidem com algumas das propensões próprias dos homens, ou propensões racionais, a saber, "o cuidado com a autopreservação, os afetos entre pai e filho, os afetos entre os sexos, o afeto para a sociedade e o desejo de destaque" (Ferguson, Instituições, 2019, p. 423).

${ }^{21}$ Do latim "aestimatione". Esse conceito é caro ao estoicismo, pois está ligado ao que deve ser escolhido ou desprezado: "[...] chamemos estimável ao que é conforme a natureza ou merece ser escolhido, por conter certo valor natural digno de apreço (dignum aestimatione), a que Zenão dá o nome de axia; e chamemos desprezível ao que é contrário ao estimável”, em: Cícero, Do sumo bem e do sumo mal. São Paulo: Martins Fontes, 2005, p. 97.

22 “[...] Com efeito, a lei de conservação [autopreservação] não exprime uma finalidade, mas um meio. $O$ homem não deve se conservar a não ser para cumprir uma destinação bem superior ao interesse de sua conservação. É o mesmo com a lei de sociabilidade: se a sociabilidade não é o fim do homem, mas um meio, necessário para alcançá-lo, é verdade, a lei de sociedade não revela nossa destinação, nem mesmo uma de suas faces. De modo que a única lei que exprime a finalidade da atividade humana na teoria de Ferguson é a lei de aperfeiçoamento [lei de apreciação]", em: Cousin, M. Cours d'Histoire de la Philosophie Morale au dix-huitième siècle. Paris: Librarie de Ladrange, 1840, p. 304.

${ }^{23}$ Da lei de apreciação surge o desejo de destaque (desire to excel) (Ferguson, Instituições, 2019, p. 423). Nos Princípios, Ferguson designa também "ambição" ou "desejo por algo superior ao que se tem no presente" (Ferguson, 1792, vol. I, p. 235) e no Ensaio, "princípio de progressão" ou "desejo de perfeição" (Ferguson, 2019, p. 36).
} 
A aprovação moral está compreendida na lei de apreciação, e é decerto o fato principal do qual inferimos a realidade dessa lei; assim como a pressão vertical e queda dos corpos são os fatos principais dos quais, na mecânica, inferimos a lei de gravitação (Ferguson, Instituições, 2019, p. 449).

A aprovação moral é um fato inferido da lei de apreciação, da mesma forma que a pressão vertical e a queda dos corpos são inferidas da lei de gravitação: a evidência da relação entre fato e lei na Teoria da mente é dada em comparação à ciência natural, justamente porque ambas dizem respeito a leis físicas da natureza.

Ora, o fenômeno da aprovação moral não poderia ser dado simplesmente pelas leis do entendimento, pois essa aprovação não diz respeito a "percepções de mera inteligência" (Ferguson, 1792, vol. II, p. 117), mas à vontade, que, de acordo com a psicologia de Ferguson, compreende as propensões, os sentimentos, os desejos e a volição. De modo similar, o objeto dessa aprovação ou sentimento moral é derivado também de uma lei da mente, a saber, a lei de sociedade:

Os homens que respeitam os direitos e sentem pelos sofrimentos de outros, que estão sempre prontos para praticarem ações de bondade, que são fiéis e verdadeiros em relação às expectativas que criaram, são considerados probos. A probidade implica amor pelo gênero humano, fundado em uma disposição compassiva, sincera e liberal. Ela está compreendida, portanto, na lei de sociedade (Ferguson, Instituições, 2019, pp. 446-447).

A probidade ${ }^{24}$ é, segundo Ferguson, "a disposição mais aprovada, e as expressões externas de probidade, as ações mais aprovadas” (Ferguson, Instituições, 2019, p. 449). Nosso autor não explicita qual ou quais fenômenos o levaram a essa inferência, apenas diz depreender a probidade como objeto da aprovação moral da lei de sociedade, pois ela "implica amor pelo gênero humano". A probidade vista como uma virtude, na verdade a mais importante delas, ${ }^{25}$ pode nos dar uma pista da possível evidência do raciocínio. Quando trata de sua filosofia moral propriamente dita, Ferguson

\footnotetext{
${ }^{24}$ Sobre a probidade, cf. Hill, J. Adam Ferguson and Ethical Integrity. Lexington Books, Maryland, 2017, p. 124

${ }^{25}$ Para os estoicos, ao contrário, é a sabedoria que tem lugar de destaque entre as virtudes - ainda que no limite tenham um caráter unitário -, pois, sendo inteligente e racional, é através da sabedoria que o homem compreende a sua natureza e o que ela lhe recomenda: "Sendo o fim da sabedoria - chamo, como vês, fim da sabedoria, termo último ou sumo bem ao que os gregos denominam télos, podendo-o chamar ainda fim das ações - $\mathrm{o}$ viver conforme e conveniente à natureza, segue-se necessariamente que todos os sábios vivem sempre em absoluta felicidade e fortuna [...]", em: Cícero, Do sumo bem e do sumo mal. São Paulo: Martins Fontes, 2005, pp. 99-100.
} 
apresenta as quatro virtudes capitais que constituem a excelência humana, ${ }^{26}$ a saber, a probidade, a sabedoria, a temperança e a fortaleza (Ferguson, Instituições, 2019, pp. 482483), que coincidem de modo geral com as quatro virtudes destacadas por Platão na República $^{27}$; com exceção da substituição da justiça por probidade. Na concepção de Ferguson apresentada acima, a probidade tem seu sentido ampliado e já aponta para a relação entre virtude individual e sociedade, que adquire grande importância no Ensaio. Ademais, a probidade é identificada com o amor ao gênero humano ou a benevolência, retomando uma noção cara ao estoicismo romano (principalmente a Sêneca e Marco Aurélio), mas também presente de forma central na filosofia moral de Hutcheson ${ }^{28}$.

\section{I.ii. Filosofia moral propriamente dita}

Craig Smith (2019) divide o pensamento moral de Ferguson em ciência moral, filosofia moral e pedagogia moral. Diferentemente, Jack Hill (2017) o divide em ciência física, ciência moral e disciplina moral. Com isso, ambos reconhecem a separação entre uma abordagem física das questões da mente, que Ferguson denomina pneumática, e uma abordagem moral, em que pese a determinação de princípios, não de fatos, a filosofia moral propriamente dita. Ademais, acrescentam uma terceira esfera, que seria a da prática moral, incluindo aí o papel do autor como professor, e preocupado em influenciar, através de suas aulas e escritos, a elite política e intelectual de seu país. Como nosso intuito é estudar o pensamento do autor com vistas à sua filosofia política, limitar-nos-emos, no que concerne à moralidade mais especificamente, à divisão de Ferguson nas Instituições de Filosofia Moral (1769), em pneumática e filosofia moral, relegando as considerações pedagógicas a alguns poucos apontamentos, ao longo de nosso texto, sobre as exortações

\footnotetext{
${ }^{26} \mathrm{Em}$ uma nota das Instituições, Ferguson diz que "de tão natural, essa divisão se faz sempre presente quando tratamos da felicidade ou excelência adequada à natureza do homem” (Ferguson, Instituições, 2019, p. 548).

${ }^{27}$ No livro IV da República, Platão destaca as quatro virtudes da cidade que posteriormente serão atribuídas aos cidadãos, são elas: a justiça, a temperança, a coragem e a sabedoria. De modo geral, várias escolas antigas também consideram essas quatro virtudes como capitais.

28"Não há tal certeza nos assuntos humanos que possa assegurá-lo da posse perpétua desses objetos que gratificam o desejo de cada um, exceto a própria virtude, a qual, uma vez que não depende de objetos ou eventos externos, mas de nossos próprios afetos e conduta, podemos garantir para nós mesmos que sempre a desfrutaremos. Assim, então, a virtude consiste na benevolência, ou no desejo do bem público [...], em: Hutcheson, An Essay on the Nature and Conduct of the Passions and Affections, with Illustrations on the Moral Sense, Indianapolis: Liberty Fund, 2002, p. 82, grifos do autor. E, em Sêneca: “O benefício é 'um ato de benevolência que traz alegria e que, por esse fato, está acompanhado da alegria' (Sêneca, Os benefícios I, 6, 1)”, em: Muller, Lire les stoïciens, Paris: PUF, 2009, p. 206.
} 
de cunho moral e político que o autor faz às classes superiores de homens, sobretudo à nobreza proprietária de terra da Grã-Bretanha.

Como dissemos, para Ferguson, a pneumática fundamenta a filosofia moral, mas não faz parte dela. Essa parte da ciência do homem dá ao filósofo condições de conhecer a natureza humana, o que quer dizer estabelecer os fatos que lhe são próprios, para posteriormente derivar a lei moral, e consequentemente sua aplicação. Mais que isso, Ferguson deixa claro que é um erro chamar de moral apenas "questões relacionadas à mente":

Em consequência desse uso vago do termo moral, qualquer questão teórica relativa à mente foi substituída por filosofia moral; e especulações de pouca importância suplantaram o estudo daquilo que os homens deveriam ser, e daquilo que eles deveriam desejar para si mesmos e para seu país (Ferguson, Instituições, 2019, p. 431, grifo do autor).

É a partir da divisão entre pneumática e filosofia moral que Ferguson fundamenta sua crítica aos sistemas morais de seus contemporâneos, especialmente de David Hume e Adam Smith, os quais teriam confundido elementos da experiência moral com os do julgamento moral, ao recorrer a noções de utilidade e simpatia ${ }^{29}$, transformando o fenômeno da aprovação moral, que é parte da pneumática, na própria filosofia moral.

De modo minucioso, no ensaio $O f$ the principle of moral estimation. A discourse between David Hume, Robert Clerk and Adam Smith, Ferguson utiliza Clerk para criticar tanto a filosofia moral de Hume quanto de Smith. Inicialmente, Clerk censura Hume, não quando usa noções como senso moral, como Hutcheson, ou simpatia, como Smith, mas quando toma como base de sua moral a noção de utilidade ${ }^{30}$ : "soa estranho dizer que a moralidade é fundada na utilidade e que a virtude é apenas uma vaca que dá certo tipo de leite”, afirma Clerk (Ferguson, 2006, p. 208) ${ }^{31}$. A crítica sarcástica não leva em conta que

\footnotetext{
29 "Há simpatia, bem como utilidade, sem aprovação; e há aprovação sem ambas; pois com frequência temos uma ideia do que deveríamos ter feito ou ter sentido muito diferente da participação que efetivamente tivemos nos sentimentos de outros homens" (Ferguson, 1792, vol. II, p. 125).

${ }^{30}$ Ferguson critica também, na esteira de Thomas Reid, o ceticismo de Hume, que, em seu entender, poderia inviabilizar a "evidência da realidade nas questões de distinção moral" (Ferguson, 1792, vol. II, p. 136). Sem se referir diretamente a Hume, o autor dedica toda uma seção dos Princípios ("Da dificuldade de se reconciliar os diferentes julgamentos dos homens relacionados à moralidade das ações externas") a dirimir os questionamentos dos céticos. Cf. Ferguson, Principles of Moral and Political Science. In two volumes. Edinburgh: printed for A. Strahan and T. Cadell, 1792, vol. II, pp. 135-148.

${ }^{31}$ Nos Princípios, lemos que "respondendo a essa objeção, o autor desse sistema [presumidamente Hume] admite 'que a aprovação moral não se estende para questões de mera utilidade física; ou é limitada à mente e suas exortações ativas'. Essa limitação, consequentemente, pode ser admitida, mas a utilidade real, mesmo nas afecções da mente, nem sempre corresponde a aprovação moral" (Ferguson, 1792, vol. II, p. 120).
} 
Hume admite a existência de virtudes desinteressadas, isto é, sem qualquer relação com sua utilidade. Outro ponto de discordância é que Ferguson diz que Hume "escolhe imputar a aprovação apenas ao efeito externo" (Ferguson, 2006, pp. 208-209). A questão é que para Ferguson "estimamos uma boa intenção ainda que por alguma circunstância seja impedida de ter efeito externo"; ora, nosso autor argumenta que quando julgamos uma ação, seja ela bem-sucedida ou não, "aprovamos a mente, não a utilidade" (Ferguson, 2006, p. 208). Quer dizer, julgamos o autor da ação, cuja intenção pode ser aprovada ou desaprovada, a despeito do seu efeito externo. Sobre isso, Ferguson igualmente pretende ignorar que quando Hume fala em efeito externo, quer dizer apenas que esse é o modo com que percebemos a intenção de um agente:

É evidente que, quando elogiamos uma determinada ação, consideramos apenas os motivos que a produziram, e tomamos a ação como signo ou indicador de certos princípios da mente e do caráter. A realização externa não tem nenhum mérito. Temos de olhar para o interior da pessoa para encontrar a qualidade moral. Ora, como não podemos fazê-lo diretamente, fixamos nossa atenção na ação, como signo externo. Mas a ação é considerada apenas um signo; o objeto último de nosso elogio e aprovação é o motivo que a produziu (Hume, 2009, p. 517).

A crítica a Smith é ainda mais incisiva: Clerk afirma que o livro Teoria dos sentimentos morais (1759) é, para ele, "uma peça completamente absurda" (Ferguson, 2006, p. 210). Em primeiro lugar, é preciso considerar que essa é uma obra que trata a moral de forma filosófica, ou seja, não tem a pretensão de instruir moralmente os homens. Em Ferguson, ao contrário, a filosofia moral está intrinsecamente ligada a uma função pedagógica, como guia de conduta para uma vida virtuosa, o que pode explicar, em parte, tamanha censura ao autor. Porém, se considerarmos uma passagem do Ensaio muito elogiosa a esse mesmo texto ${ }^{32}$, podemos entender o escárnio apenas como uma provocação do personagem. A crítica que podemos atribuir a Ferguson a seu colega é a utilização da simpatia como mecanismo dos juízos morais ${ }^{33}$.

Para Smith, a simpatia 34 “denota a nossa comiseração por uma paixão qualquer” (Smith, 1976, p. 10). Ela surge sempre que nos colocamos na posição de outra pessoa a

\footnotetext{
${ }^{32} \mathrm{Na}$ edição de 1773 do Ensaio, Ferguson diz que "especulações sobre o comércio e a riqueza foram realizadas pelos mais talentosos autores [...]", com referência a Smith: "Pelo sr. Smith, autor de Teoria dos sentimentos morais" (Ferguson, 2019, p. 210).

${ }^{33}$ Nos Princípios, Ferguson admite o papel da simpatia na experiência moral, embora não atribua a ela nossa capacidade de aprovação moral (Ferguson, 1792, vol. I, p. 125 e vol. II, p. 17).

${ }^{34}$ Cf. Raphael, D. D. The Impartial Spectator. Oxford: Oxford University Press, 1975. A simpatia tem uma posição central na filosofia de Adam Smith, pois é a base dos juízos morais, compreendendo, assim,
} 
ponto de compartilhar de sua alegria ou tristeza. No entanto, simpatizar pela dor ou contentamento alheio não significa meramente formar uma ideia de como tal pessoa sofre, mas principalmente imaginar como nós mesmos nos sentiríamos em uma situação semelhante: "através da imaginação colocamos a nós mesmo na sua situação, concebemos a nós mesmos suportando todos os mesmos tormentos, é como se entrássemos em seu corpo e nos tornássemos de alguma maneira a mesma pessoa, e, então, formássemos a mesma ideia de suas sensações e até sentíssemos algo que, embora em um grau mais fraco, não seria totalmente diferente do que ela próprio sente" (Smith, 1976, p. 9). Assim, um espectador pode sentir prazer na medida em que compartilha a felicidade de outra pessoa, ou dor quando compartilha de um sentimento oposto; mas mais que isso, é capaz de julgar, a partir da concordância ou dissonância de seus próprios sentimentos, se a reação assim expressa foi apropriada ou inadequada.

Aprovar as paixões de outras pessoas como adequada a seus objetos é o mesmo que observar que simpatizamos inteiramente com elas, e desaprová-las é o mesmo que observar que não nos simpatizamos inteiramente com elas. O homem que se ofende com as injúrias que me foram causadas e observa que eu me ofendo precisamente como ele, necessariamente aprova meu aborrecimento (Smith, 1976, p 16).

Embora esse seja o primeiro passo para nossa aprovação ou desaprovação, nosso julgamento moral não se restringe à identificação que sentimos pela atitude alheia, pois senão apenas aprovaríamos o que está de acordo com nossas próprias maneiras e costumes, e não seríamos capazes de considerações morais mais universais. Para dar conta desse segundo momento, Smith lança mão da ideia de um espectador imparcial: os homens têm naturalmente um parâmetro para julgar a si mesmos, que é "um critério ou referência internalizado do que é bom ou ruim” (Berry, 2018/b, p. 40). Portanto, somos capazes não só de julgar a partir do nosso acordo ou desacordo com uma situação particular, mas com o que acreditamos ser mais adequado ou inadequado a partir de um ponto de vista mais amplo, ou seja, reconhecemos naturalmente certos valores morais.

A observação de Clerk vai ao encontro desses dois momentos da operação da simpatia. Segundo ele, se, por um lado, não houvesse um espectador imparcial, a simpatia só explicaria o consenso ou dissenso entre as pessoas e, portanto, não teria nada que ver com a moralidade; por outro lado, quando se lança mão de tal expediente, então "é

suas considerações sobre a virtude e a justiça. Dessa perspectiva, a discordância de Ferguson é essencial e se opõe de modo geral a todo o sistema moral smithiano. 
conveniente poder trazer a própria virtude em seu auxílio na ocasião da simpatia falhar" (Ferguson, 2006, p. 210). Para Ferguson o espectador imparcial é o próprio indivíduo virtuoso e, logo, a noção de virtude é introduzida para explicar a simpatia sem que se explique como chegamos a ela.

Embora essa seja uma boa crítica à Smith, Ferguson não dá prosseguimento a sua argumentação e termina o ensaio apresentando suas próprias ideias, na figura de Clerk, sobre a moralidade: "a questão importante e genuína da Filosofia Moral [é] $d e$ finibus ou qual é a finalidade" (Ferguson, 2006, p. 214) da vida humana. Essa noção é uma referência direta ao De finibus de Cícero. Ali, o filósofo romano discute um ponto que causa grande "discórdia entre os mais doutos filósofos", isto é, "o que é mais excelente e verdadeiro em toda ocupação da vida" (Cícero, 2005, p. 6). O intuito de Cícero é examinar em latim as principais escolas morais gregas, a saber, o epicurismo, o estoicismo e a Academia. Ferguson, por sua vez, declara-se mais inclinado para a escola estoica:

O autor, em algumas afirmações que se seguem, pode ser considerado parcial em relação à filosofia estoica [...]. Os estoicos conceberam a vida humana por meio da imagem de um jogo, no qual o entretenimento e o mérito dos jogadores consistiam em jogar bem e atentamente, quer a aposta seja grande ou pequena (Ferguson, 1792, vol. I, p. 7).

Não é difícil encontrar na filosofia moral de Ferguson motivos que corroboram essa filiação, apesar das evidentes divergências. Nosso autor confere centralidade ao mote estoico de que a virtude é o verdadeiro bem e suficiente para a vida feliz ${ }^{35}$, excluindo, portanto, certas vantagens exteriores concebidas pela tradição aristotélica, como riqueza e saúde, e mesmo prazeres em geral, como defendia a escola Epicurista. Além disso, o estoicismo é a escola cuja teoria oferecia um guia para a conduta correta e para o aperfeiçoamento, parte fundamental da ciência moral de Ferguson.

A filosofia moral, preocupada com o que os homens devem ser, com a finalidade da existência humana, é endereçada aos seres inteligentes e livres (dotados de entendimento e de vontade), e que, portanto, podem escolher o que é bom ${ }^{36}$. Como vimos na Teoria da mente, a única lei física da vontade que aponta para uma finalidade, para o

\footnotetext{
${ }^{35}$ Ferguson iguala bom, virtuoso e feliz, mas abandona outras noções estoicas como honesto e louvável. Em Do sumo bem e do sumo mal, Cícero, em conversa com Catão, pergunta: "Se não tens por bem senão a virtude e aquilo que dizes honesto, reto, louvável decoroso (uma vez que todas essas palavras expressam uma mesma e só coisa), que outra coisa terás que buscar?", em: Cícero, Do sumo bem e do sumo mal. São Paulo: Martins Fontes, 2005, p. 94.

36“Filosofia moral é o conhecimento daquilo que deve ser, ou a aplicação de regras que devem determinar a escolha de agentes voluntários" (Ferguson, Instituições, 2019, p. 388, grifo nosso).
} 
devir da existência humana, é a lei de apreciação. Igualmente, na filosofia moral, essa lei, que nada mais é que uma propensão ao aperfeiçoamento, determinará o princípio da moral: "a lei moral, enquanto aplicada a naturezas inteligentes, é qualquer expressão geral do que é bom" (Ferguson, Instituições, 2019, p. 467). Nota-se, portanto que, embora a lei moral não seja expressão de um fato ${ }^{37}$, ela só pode ser derivada de uma lei física, ou seja, de uma característica da natureza humana apreendida por nós a partir da Teoria da mente; é por essa razão que Ferguson afirma que "a pneumática, ou a história física da mente, é a fundação da filosofia moral" (Ferguson, Instituições, 2019, p. 388).

Podemos entender dessa argumentação que, para Ferguson, a capacidade de apreender o que é bom a partir da experiência (seres inteligentes, leis do entendimento) permite aos homens escolherem o que é bom (seres livres, lei da vontade), quer dizer, implica "uma obrigação de determinar [nossa] escolha" (Ferguson, Instituições, 2019, p. 468). Portanto, é da apreensão do princípio da moral que nosso autor deriva a necessidade moral. Cabe ressaltar que se trata realmente de uma apreensão, não de uma compreensão racional ${ }^{38}$. Nos Princípios, ele diz que "é difícil nomear o poder pelo qual o homem é capaz de distinguir entre certo e errado, sem recorrer a apelações gerais de algumas de suas outras faculdades, como sentido, percepção ou julgamento". Dada a dificuldade, ele chama a capacidade de distinção moral de "poder judicativo", ou seja, é uma inclinação natural dos homens, distinta de qualquer outra faculdade (Ferguson, 1792, vol. II, p. 127). Em Ferguson, esse poder não tem, como para Hutcheson, por exemplo, um lastro fisiológico: é uma característica da natureza humana que pode ser apreendida, porém não determinada.

Ora, se o aperfeiçoamento moral aponta para um exercício cuja finalidade é a escolha do que é bom, cabe aqui um questionamento: o que quer dizer bom? E se somos igualmente capazes de distinguir bem e mal, o que é mal? A questão é colocada nos seguintes termos:

Como bem e mal implicam contentamento e sofrimento, consequentemente eles dizem respeito exclusivamente a seres sensitivos e inteligentes. A suposta causa de contentamento é um objeto de desejo. A suposta causa de sofrimento é um objeto de

\footnotetext{
37 "Resta-nos saber como Ferguson consegue converter o fato em lei e deduzir o princípio dos direitos e dos deveres", em: Cousin, M. Cours d'Histoire de La Philosophie Morale au dix-huitième siècle. Paris: Librarie de Ladrange, 1840, p. 300.

${ }^{38}$ Ferguson, como Hume e Smith, criticou os sistemas morais que consideravam "a própria razão ou o entendimento" como responsáveis por nossa "observação da adequação das coisas" e que admitiram "a razão humana como princípio do discernimento moral” (Ferguson, 1792, vol. II, p. 117).
} 
aversão. O que não se supõe ser a causa de ambos é indiferente (Ferguson, Instituições, 2019, p. 388).

Dessa forma, quais são as coisas sempre boas e que devem ser desejadas? Quais são aquelas que nos causam mal e devem ser evitadas? Essas perguntas correspondem, em termos gerais, ao objeto mesmo da moralidade, ou seja, aquilo que nos leva à aprovação ou desaprovação moral. Baseando-se nas leis físicas da mente (lei de autopreservação, lei de sociedade e lei de apreciação), Ferguson deriva alguns predicados de bom e mau: vida e morte, prazer e dor, excelência e defeito, felicidade e miséria (Ferguson, Instituições, 2019, p. 477). Vida e morte, prazer e dor não são objetos próprios do desejo dos homens, eles contemplam também os animais, que são seres sensíveis e regidos pela lei de autopreservação. Inerente apenas aos homens e objeto mais importante da moralidade é apenas a excelência, que é sinônimo de virtude e de felicidade. Ferguson descarta o que chama de "opinião vulgar" ou senso comum, aquela que considera a felicidade a partir do desejo satisfeito (Ferguson, Instituições, 2019, p. 483). Ao contrário, nosso autor afirma que a felicidade é "uma qualidade pessoal, não um atributo de condição externa" e que, portanto, coincide com "as definições de virtude" (Ferguson, Instituições, 2019, p. 484):

Apenas a mente benevolente, sábia e corajosa, que tem os contentamentos mais elevados e menos sofridos pode ser considerada feliz. Essas qualidades contêm em si mesmas o uso e o valor pelos quais elas são desejáveis. Os homens que não as têm podem nutrir opiniões diferentes a respeito delas; mas aqueles que as têm, devem saber que são felizes. Elas devem ser escolhidas à despeito de qualquer tipo de prazer e sob o risco de qualquer sofrimento do qual eles não estão isentos. Isto é o que Epicteto e Antonino quiseram dizer por: "Que a virtude é o único bem” (Ferguson, Instituições, 2019, pp. 483-484).

Assim, a felicidade dos homens independe de qualquer objeto externo para sua realização, é uma afecção da mente e não uma condição circunstancial. Considerações sobre satisfação e prazer dizem respeito apenas à sua existência animal, cuja finalidade é a autopreservação. A finalidade da existência humana, ao contrário, é a virtude ou excelência. A relação entre virtude e felicidade, central na filosofia moral de Ferguson, é desfeita por Hume, para quem "a felicidade humana, de acordo com as noções mais aceitas, parece compreender três ingredientes: ação, prazer e indolência [...]” (Hume, 1994, pp. 269-270). Hume critica, ademais, a severidade dos moralistas que viam na "pobreza e rusticidade", "virtude e espírito público" dos antigos romanos motivos para 
sua grandeza (Hume, 1994, p. 275). Ferguson, ciente da reprovação que sofria dos seus contemporâneos, afirma que "os filósofos foram censurados por recomendar uma perfeição elevada demais para a natureza humana"; mas, responde ele, "seria razoável, portanto, recomendar defeitos?” (Ferguson, Instituições, 2019, p. 487) ${ }^{39}$. É exatamente porque os homens concebem a perfeição que devemos tê-la como guia ${ }^{40}$.

A perfeição, em Ferguson, não é uma noção simplesmente moral; com efeito, ela é um efeito da perfeição do próprio sistema da natureza, que pode ser observada no ajuste harmonioso e beneficente entre as partes e o todo da natureza.

É provável, no entanto, que a apreensão de um desígnio beneficente na natureza tenha sua fonte em algum exemplo que seja realmente adequado para justificar tal concepção. Como na construção primorosa e no desígnio óbvio que aparecem na estrutura dos órgãos animais. Esses, no caso de um animal qualquer, são acompanhados de uma direção instintiva para usá-los. O pintinho, quase imediatamente após ter escapado da casca, corre para sua comida, e utiliza seu bico para pegá-la. O quadrúpede, logo após ter nascido, pisa o chão com seus pés, e tateia procurando a teta que fornecerá seu alimento. Esse direcionamento instintivo, quando combinado com inteligência na natureza do homem, significa uma percepção que o órgão foi feito para o propósito a que é aplicado. Quem duvida que o olho foi feito para ver, o ouvido para ouvir, a boca para receber e os dentes para triturar a comida; que o pé foi feito para pisar o chão; a mão para agarrar ou permitir que se segure ou empregue coisas apropriadas para o seu uso (Ferguson, 1792, vol. I, p. $165)$.

Essa concepção de natureza pode ser identificada ao perfeccionismo estoico, mas é sobretudo expressão de uma teleologia de feitio naturalista, uma versão pragmática, ou melhor, heurística do esquema estoico-aristotélico que vincula a inteligibilidade da forma à apreensão de sua função ${ }^{41}$. A estrutura anatômico-fisiológica nos animais de modo geral mostra que há um desígnio, uma intencionalidade, que é a preservação dos indivíduos e da espécie. O bico do pintinho e os pés do quadrúpede têm uma forma adequada à função para a qual serão utilizadas, isto é, comer e andar. No caso dos homens, há uma diferença (que como vimos, não é uma diferença apenas de grau, mas mesmo de

\footnotetext{
${ }^{39} \mathrm{Na}$ introdução aos Princípios, lemos: "Se sua investigação o levou a concordar com os princípios defendidos há mais ou menos dois mil por uma escola de filósofos isso significa que o autor foi realmente corroborado em sua noção, não obstante o nome dessa escola ter se tornado, para a nobreza dos tempos modernos, proverbial para estupidez" (Ferguson, 1792, vol. I, p. 7).

40 "A apreensão do que é perfeito é o guia e incentivo para o aperfeiçoamento" (Ferguson, Instituições, 2019, p. 487).

${ }^{41}$ Cf. Pimenta, P. P. A trama da natureza. São Paulo: Editora Unesp, 2018.
} 
qualidade): são dotados, além das formas cuja função é sua autopreservação, de inteligência, que os leva a apreender uma noção do todo da Natureza como ordem. Todavia, ainda que a inteligência seja uma capacidade qualitativamente superior às formas instintivas dos animais, ela supõe também um desígnio, igualmente natural: a finalidade dos seres inteligentes é propriamente a perfeição moral, que se realiza nas ações dos homens guiados pela razão.

Há duas posições divergentes sobre a teleologia fergusoniana. Craig Smith (2019) admite uma concepção de perfeccionismo sem uma teleologia muito clara; para ele, haveria no autor algo como uma teleologia mitigada, pois "Ferguson não nos fornece qualquer vislumbre de um télos ou ideal que não seja em platitudes as mais banais” (p. 88). Ora, há muito claramente uma teleologia na filosofia moral de Ferguson, e o ideal do autor repousa numa noção de excelência moral, que, desde a tradição clássica, expressase na recomendação da virtude, ainda que tal perfeição nunca possa ser alcançada. Em sentido oposto, Lisa Hill (2006), vê na ideia de perfectibilidade do autor uma "estrutura teleológica e providencial". Além disso, a comentadora afirma que, "apesar da teleologia e do Providencialismo, a insistência de Ferguson na sociabilidade fundamental da espécie, e a maneira com que esse fato afeta os impulsos individualizantes, ajudou a criar espaço para o desenvolvimento posterior da ciência social propriamente dita" (p. 98). Com efeito, Ferguson concebe um providencialismo de tipo estoico; no entanto, combinao com uma abordagem naturalista da religião, igualmente imanente, que tem a função de "explicar a aparente existência de ordem e significado na natureza" (Smith, 2019, p.132). Tal ordenação da natureza, sua perfeição, é a evidência da existência de um criador. Esse é o argumento da prova de Deus, que, como afirma Pedro Paulo Pimenta (2018), “é o 'argumento experimental', de que os seguidores de Newton lançam mão para demonstrar a existência de Deus a partir da experiência” (p. 73). Na verdade, embora Ferguson professasse a religião cristã, há poucos argumentos religiosos na sua filosofia e quase nenhuma referência à religião revelada, ou transcendente ${ }^{42}$.

Ademais, o modelo de perfeccionismo de Ferguson não está relacionado, como na tradição estoica, a um fatalismo ${ }^{43}$, quer dizer, os fatos da existência não são

\footnotetext{
${ }^{42}$ Como nos lembra Craig Smith (2019), "a combinação de estoicismo e cristandade" foi comum a um grupo que ficou conhecido como "Moderate literati of Edinburgh", termo cunhado por Richard Sher (1985), com referência a ministros da igreja (Kirk) da Escócia que se consideravam herdeiros intelectuais de Francis Hutcheson. Cf. Sher, R. Church and University in the Scottish Enlightenment: The Moderate Literati of Edinburgh. Edinburgh: Edinburgh University Press, 1985.

${ }^{43}$ Nos Princípios, Ferguson critica explicitamente a noção de necessidade do fatalista: "O conhecimento que atribuímos ao Autor da natureza compreende, sem dúvida, o que quer que resulte de uma fonte contingente, que ele deixou aberta na liberdade da inteligência de suas criaturas, e sua providência onipotente é suficiente para controlar os efeitos de tal liberdade [...]. Os decretos do poder onipotente não
} 
predeterminados pela natureza. Isso se explica pela separação das leis de natureza em lei moral e lei física, permitindo ao autor considerações, por um lado, finalistas a respeito da humanidade, e, por outro, uma abordagem de caráter mais científico, no sentido moderno, cuja influência é Bacon e Newton; segundo Ferguson, nas Instituições, "as leis físicas referem-se apenas a causas eficientes; tais são, portanto, os objetos imediatos da ciência" (Ferguson, Instituições, 2019, p. 385). Na filosofia moral, uma exceção é feita, a título de complemento, de resto conforme as recomendações de Bacon: o recurso às causas finais se legitima apenas e tão somente quando as causas eficientes se mostram insuficientes para explicar um fenômeno. Pode-se dizer que é a visada humana sobre a Natureza que é teleológica, e não a Natureza enquanto tal.

\section{I.iii. A lei de moralidade e suas aplicações}

Fazendo coincidir a felicidade e a virtude, Ferguson termina por indicar que esse é o verdadeiro objeto de sua filosofia moral, a lei fundamental de moralidade, e que a partir dela devemos derivar regras de conduta para uma existência feliz. A filosofia moral propriamente dita é, portanto, não somente o conhecimento da lei moral, mas também sua aplicação tanto para a mente quanto para as ações externas em geral.

A lei de moralidade, "o maior bem apropriado para a natureza do homem é o amor pelo gênero humano" (Ferguson, Instituições, 2019, p. 493). Essa lei tem duas aplicações: à mente e às ações externas. Dizer que essa lei se aplica, em primeiro lugar, à mente é fundamental, pois para Ferguson e a para a escola estoica, a virtude é uma qualidade da mente e não tem relação com objetos externos: uma disposição virtuosa é suficiente para a felicidade, a despeito, por exemplo, de riquezas ou de saúde. Dessa forma, sua aplicação se resolve na recomendação das virtudes capitais: além do amor pelo gênero humano (probidade ou benevolência), a sabedoria, a temperança e a fortaleza.

Felicidade e miséria, bondade e maldade, são qualidades da mente. A distinção entre certo e errado subsiste nessas qualidades. Essa distinção é encontrada na oposição entre benevolência e malignidade, entre sabedoria e tolice, entre coragem e medo e entre ocupação racional e sensualidade e dissipação. A lei fundamental de moralidade requer

são menos eternos por serem feitos em um ponto de duração em detrimento de outro. A data da existência deles é sempre presente. Tal é o eterno Agora, para o qual nos empenhamos, mas quiçá em vão, para elevar nossos pensamento sobre o assunto. A consequência que o fatalista tiraria da suposta necessidade da ação humana é igualmente absurda" (Ferguson, 1792, vol. I, p. 155, grifo do autor). 
um afeto determinado em sua natureza, mas indefinido a respeito de seu objeto. $\mathrm{O}$ afeto é constituído por uma disposição compassiva e benevolente (Ferguson, Instituições, 2019, p. 494).

O que aprovamos ou desaprovamos no nosso julgamento moral é, portanto, essa "disposição compassiva e benevolente" da mente.

A passagem para a segunda aplicação da lei de moralidade, às ações externas, não se dá facilmente: é preciso conciliar o fato de que, no limite, a disposição virtuosa é suficiente para nossa aprovação moral, com a possibilidade "de discernimento moral" também de seus efeitos externos, ou seja, com o fato de que as ações que decorrem dessa disposição possam também ser dignas de "elogio e censura" (Ferguson, 1792, vol. II, p. 113). Assim, embora o efeito externo de uma disposição virtuosa não possa ser tomado como o objeto de discernimento para explicarmos a aprovação moral, a ação humana é igualmente passível de julgamento e constitui uma parte importante da filosofia moral. Na verdade, a dificuldade não está na nossa consideração da virtude, no seu valor enquanto afecção da mente, pois, segundo Ferguson, "até para aqueles que estão longe de considerá-la como felicidade, é ainda uma questão de apreço e respeito" (Ferguson, 1792, vol. II, p. 116), mas sim na diversidade de opiniões que envolvem as ações humanas; por exemplo, "o que é considerado inocente e digno de elogio em um país, é considerado uma ofensa abominável em outro. As definições de roubo, assassinato ou traição são diferentes nas leis de diferentes países" (Ferguson, Instituições, 2019, p. 496). Dessa forma, estabelecer um critério moral para as ações externas é uma tarefa mais difícil, o que fez com que alguns autores recorressem, por exemplo, à noção de utilidade ${ }^{44}$ : uma ação útil é moralmente aprovada e uma contrária, inútil, é reprovada. Contra o critério da utilidade, Ferguson argumenta que "a mera tentativa de um homem virtuoso de servir a seu amigo ou a seu país é um objeto de apreciação moral, não apenas onde ele pode ter falhado em seu propósito, mas mesmo onde o evento pode ter sido calamitoso para ele próprio e para outros" (Ferguson, 1792, vol. II, p. 120). Ora, é claro que muitas ações virtuosas são úteis, porém, esta não pode ser a causa daquela: o que a tornou virtuosa foi a boa disposição de seu agente e não seu efeito externo.

\footnotetext{
${ }^{44}$ Como vimos, para Ferguson, Hume explica o fenômeno da aprovação moral através da noção de utilidade. Nos Princípios, em presumida referência a Hume, nosso autor diz que "em resposta a essa objeção [de que há muitos exemplos de grande utilidade mas que não resultam em aprovação moral] o autor desse sistema admitiu que 'a aprovação moral não se estende a mera questão de utilidade física, ou que é limitada à mente e suas exortações ativas"” (Ferguson, 1793, vol. II, p. 120).
} 
Fonte de inspiração de Ferguson, a filosofia moral estoica colocou o problema da seguinte maneira: se, por um lado, o verdadeiro bem deve ser sempre escolhido ${ }^{45}$, perfeição encarnada pela figura do sábio, por outro, para auxiliar os homens comuns na sua conduta diária, estabeleceu-se uma doutrina dos preferíveis e dos deveres ${ }^{46}$. Segundo essa doutrina, mesmo dentre as coisas indiferentes para se alcançar o supremo bem, ou seja, o verdadeiro objeto da aprovação moral, há aquilo que deve ser preferido, como, por exemplo, de modo geral a riqueza é preferível à pobreza, bem como a saúde à doença. Essa preferência comporta uma explicação razoável (Cícero, 2005, p. 112), de acordo com Diógenes Laércio, é uma ação que "uma vez realizada, possui uma justificativa razoável”, pois "é uma atividade que é apropriada às constituições conforme a natureza" ${ }^{47}$. De forma complementar, os deveres são os "modelos de comportamento" para orientar essas preferências: "se a riqueza é preferível, o exercício de uma atividade que permite obter os meios de vida é um dever" (Muller, 2009, p. 209). Dessa forma, a ética estoica também "tende a cobrir mais largamente o campo das condutas humanas" e seus adeptos são convidados a "se casar, a ter filhos, a ocupar oportunamente as funções públicas, a não viver apartado, a não se distinguir em sua vestimenta ou suas maneiras" (Muller, 2009, p. 210).

É nesse mesmo sentido que Ferguson pensará a lei de moralidade aplicada às ações externas dos homens: o critério de conduta é sempre o bem da humanidade; no que diz respeito aos assuntos importantes, ele deve orientar nossas ações, porém, nos indiferentes, cabe seguir o que é preferível, ou seja, as leis e costumes de um país:

Em assuntos indiferentes, devemos observar as maneiras de nosso país, enquanto falamos sua língua e usamos seu vestuário. Em assuntos de importância, devemos escolher o que é para o bem do gênero humano, em oposição à opinião e ao costume. Assim, nós devemos fazer o que quer que tenda a promover bondade, a evitar corrupção e a assegurar os direitos do gênero humano, e a evitar o que quer que tenda a corromper ou seduzir e o que quer que tenda a abrir caminho para a opressão (Ferguson, Instituições, 2019, pp. 499-500).

\footnotetext{
${ }^{45}$ Segundo a moral estoica, o verdadeiro bem deve ser sempre escolhido da mesma forma que o mal deve ser sempre repelido. Há ainda as coisas indiferentes, como a riqueza e a saúde, que não concorrem para a obtenção da felicidade. Nessa concepção, não há uma gradação ou um intermediário entre a virtude e seu contrário, ou entre o sábio e o tolo.

${ }^{46}$ Essa teoria foi sistematizada inicialmente por Cícero, supostamente a partir da filosofia de Zenão; em Do sumo bem e do sumo mal, Cícero, através de Catão, fala do valor intermediário que se pode atribuir aos indiferentes. Em Dos deveres, considerado mais próximo ao estoicismo, Cícero trata exatamente da prática moral.

${ }^{47}$ Diógenes Laércio, em.: Muller, R. Lire les stoïciens. Paris: PUF, 2009, p. 115.
} 
Nota-se que a filosofia moral aqui alcança uma dimensão política e se entrelaça com as instituições sociais. A lei de moralidade se desdobrará a ponto de formar a jurisprudência, a casuística e a política, ciências que em Ferguson estão intimamente ligadas à filosofia moral.

\section{I.iv. Da virtude individual para a virtude em sociedade: a nação feliz}

Como vimos na teoria da mente, o objeto de aprovação moral estabelecido a partir dos fatos da natureza humana era a probidade, que implica amor pelo gênero humano ou benevolência (Ferguson, Instituições, 2019, p. 447) e coincide com a justiça, uma das quatro virtudes capitais da tradição moralista antiga. Da mesma forma, na filosofia moral, o amor pelo gênero humano é "o maior bem apropriado para a natureza do homem" (Ferguson, Instituições, 2019, p. 493), a virtude por excelência. Quando salienta que a virtude principal diz respeito ao "bem do gênero humano", Ferguson faz uma ligação entre o indivíduo virtuoso e a sociedade, entre o particular e o universal, destacando a dimensão política da virtude. Segundo J. G. A. Pocock (1975), Ferguson resolve esse "problema do bem universal versus particular" 48 de uma forma “impressionantemente primitivista" (p. 500). Na verdade, é a sociabilidade natural dos homens que garante essa articulação: para David Kettler (1965), "a virtude é, afinal, a perfeição da natureza humana, e a natureza humana é inconcebível sem a sociedade" (p. 188). Ora, se em Ferguson a lei fundamental de moralidade é o amor pelo gênero humano, sua consequência imediata é que "o bem das comunidades, ou do gênero humano, é igualmente aquele do indivíduo" (Ferguson, Instituições, 2019, p 493).

Dois elos, na visão de Ferguson, vinculam a compreensão da virtude à compreensão da sociedade. Primeiro, a virtude individual requer conhecimento sobre a finalidade verdadeiramente boa da sociedade e sobre os meios apropriados para se alcançar tal finalidade, pois o amor pela humanidade manifesto no benefício social ativo é o principal atributo da virtude. Em segundo lugar, os promotores da virtude devem aprender sobre a sociedade porque, acredita Ferguson, a virtude humana só pode surgir em sociedade, e mais especificamente - só pode surgir, via de regra, em um tipo de sociedade que fornece

\footnotetext{
${ }^{48}$ Pocock resume a questão da seguinte maneira: "O problema foi sempre o de decidir quando os bens particulares ou privados devessem ser vistos como contribuintes ou concorrentes para o bem público ou universal" (Pocock, 1975, p. 500). Convém lembrar que a querela se intensificou com a afirmação de Mandeville de que são os vícios privados os responsáveis pelos benefícios públicos, e não as virtudes sociais.
} 
a ele estímulo e encorajamento. Enfim, Ferguson reduz esses dois elos a um (Kettler, 1965, p. 188).

Portanto, há uma relação intrínseca entre a felicidade individual (happines) e a felicidade nacional (felicity): no Ensaio, lemos que "é assim o Estado mais feliz, o mais amado por seus súditos; e são mais felizes os homens cujo coração se engaja junto à comunidade" (Ferguson, 2019, p. 99). Essa relação se desdobra na ligação entre homens e sua comunidade, entre o emprego de seus talentos e o bem-estar do Estado, mesmo porque, como para o homem virtuoso os objetos externos são frutos do acaso e não concorrem para a sua felicidade, "riqueza, comércio, extensão territorial e conhecimento das artes" (Ferguson, 2019, p. 99) podem até contribuir para a conservação de uma nação (como a comida, o vestuário e a moradia contribuem para a preservação dos homens), mas não constituem a sua verdadeira felicidade: "a força de uma nação deriva do caráter, não da riqueza, tampouco do número de pessoas que a constituem" (Ferguson, 2019, p. 102).

Como vimos, a lei moral prescreve ao homem virtuoso a probidade ou a benevolência, que nada mais é que o amor pelo gênero humano. De modo mais concreto, esse amor pode ser traduzido como o engajamento político dos membros de uma dada sociedade no seu bem-estar, isto é, o espírito público. O que é a sociedade e como ela se constitui é tema do próximo capítulo. 


\section{Capítulo II}

\section{História natural da sociedade}

A filosofia moral de Ferguson entrelaça uma concepção de homem virtuoso a uma concepção de sociedade virtuosa. Segundo Kettler (1965), a investigação sobre o homem nos leva a duas perguntas: "quais contribuições os homens virtuosos podem fazer para sua sociedade" e "qual contribuição a sociedade faz para a virtude humana?" (p. 188). No capítulo anterior, tentando responder à primeira pergunta, mostramos que no âmbito individual, a virtude é pensada à luz da tradição antiga, de matriz estoica, baseada na recomendação das virtudes capitais. Apesar disso, nosso autor tenta apoiar sua moral num estudo empírico da natureza humana, a pneumática, que inclui uma parte descritiva, a história natural do homem - do indivíduo e da espécie -, e "uma explicação ou teoria dos principais fenômenos da vida humana" (Ferguson, Instituições, 2019, p. 388).

Neste capítulo, no registro da pneumática, trataremos da história natural do homem $^{49}$, ou mais especificamente, da história natural da espécie humana, que para Ferguson é a própria história da sociedade civil. Nossa investigação tem o intuito, se não (ainda) de responder à segunda pergunta colocada acima, que é assunto para um terceiro capítulo - dedicado à filosofia política -, ao menos de compreender a relação entre homem e sociedade (entre indivíduo e espécie).

Assim, para entendermos o que nosso autor considera por história da sociedade civil quando dá título ao Ensaio, indicaremos, em primeiro lugar, que a história ocupa um lugar metodológico importante na teoria do conhecimento do autor, a partir da tripartição dos saberes tal como pensada por Bacon. Depois, apontaremos para o fato de que, para Ferguson, não há somente um tipo de história, mas dois, e qual deles é mais adequado à sociedade civil. Em seguida, demonstraremos como essa história pode ser elaborada através de etapas ou estágios de seu progresso para, por fim, apresentar um esboço teórico do seu desenvolvimento, desde os primórdios rudes, com os selvagens, até as formas mais refinadas, a sociedade civil propriamente dita.

\footnotetext{
${ }^{49}$ Para Ferguson, a pneumática se refere "aos fenômenos da vida humana" e contém a "história da natureza humana". Nas Instituições, lemos que "a história do homem contém ou fatos conforme ocorrem em uma visão geral da espécie ou conforme ocorrem para o indivíduo, quando relembra o que se passa em sua própria mente. Os primeiros podem ser denominados a história da espécie, os segundos, a do indivíduo" (Ferguson, Instituições, 2019, p. 389, grifos do autor).
} 


\title{
II.i. Dois tipos de história
}

Nas Instituições, na seção de abertura, Do conhecimento em geral - com referência do próprio Ferguson ao Novo Órganon de Francis Bacon - lemos que "todo conhecimento é ou conhecimento de fatos particulares ou de regras gerais" (Ferguson, Instituições, 2019, p. 383) e, em seguida: "uma coleção de fatos, descritos ou narrados, constitui história. Regras gerais, e suas aplicações, para regular ou explicar particularidades, constituem ciência" (Ferguson, Instituições, 2019, p. 384). Assim, o conhecimento humano se dá por duas formas, ou enquanto história, ou enquanto ciência. Em outro texto, Ferguson acrescenta ainda uma terceira fonte de conhecimento, a arte:

\begin{abstract}
A história é o conhecimento detalhado de particulares. A ciência é o conhecimento de princípios gerais. A arte é o poder fundado em conhecimento ou hábito, pelo qual os homens realizam certas funções da mente ou produzem algum objeto externo (Ferguson,
\end{abstract} 1766, pp. 3-4).

Para entendermos essa tripartição, voltemos a Bacon: no Progresso do conhecimento, o autor afirma que "as partes do conhecimento humano fazem referência às três partes do entendimento humano, que é a sede do saber: a História à sua Memória, a Poesia à sua Imaginação e a Filosofia à sua Razão” (Bacon, 2007, p. 112). Há, portanto, três formas de conhecimento, que coincidem com a divisão de Ferguson em história, arte e ciência.

Há ainda, em Bacon, uma subdivisão da história em História Natural e Civil ${ }^{50}$, esta última compreendendo a história eclesiástica, a história literária e a história civil propriamente (Bacon, 1999, p. 73) ${ }^{51}$. Essa subdivisão da história é decorrente dos objetos com os quais cada uma delas lida: a história natural trata das obras da natureza, a história civil, das obras do Estado civil, a história eclesiástica das obras do Estado eclesiástico e a última, a história literária, ainda deficiente segundo Bacon, trataria do "estado geral do saber ao longo das épocas" (Bacon, 2007, p. 112). Em relação à história natural, Bacon afirma que há ainda uma outra forma de subdividi-la, de acordo com seu uso e finalidade:

\footnotetext{
${ }^{50}$ É preciso apontar que embora haja uma separação entre esses dois tipos de história, elas estão ligadas, como Bacon assinala, pela mesma sede do saber, ou seja, a memória. Paul Wood, em seu artigo The natural history of man in the Scottish Enlightenment, diz que Bacon as ligava na medida em que "envolviam de modo comum a coleção tanto de antiguidades quanto de espécimes dos três reinos da natureza" (Wood, 1989, p. 95).

${ }^{51}$ Há uma variação dessa subdivisão no Progresso do Conhecimento, onde a história é desdobrada em quatro partes, não em duas, pois as histórias Eclesiástica e Literária são apresentadas como categorias singulares: "a História é Natural, Civil, Eclesiástica e Literária" (Bacon, 2007, p. 112).
} 
ela pode ser narrativa, quando dispõe seus objetos para fins de mero conhecimento, ou pode ser indutiva, quer dizer, quando utilizada para "a mais nobre finalidade da História Natural" que é ser auxílio e orientação "para a construção da filosofia" (Bacon, 1999, p. 73).

A história da natureza reúne compilações de fatos naturais, "em seu curso normal", "em seus erros ou variações" ou de forma alterada ou trabalhada (Bacon, 2007, p. 113) enquanto a história civil propriamente dita diz respeito a ações e eventos dos homens em relação ao Estado civil (Memoriais, Histórias Completas e Antiguidades). Isso quer dizer que pode haver uma história natural do homem, que compreende, além de suas características naturais, seus produtos artificiais; como exemplo, há a história fisionômica e anatômica do homem bem como a história do vinho e das adivinhações, mas ações e "comportamento público das pessoas" (Bacon, 2007, p. 119), seus negócios, suas atividades são catalogados como história civil.

Em Ferguson, há igualmente uma divisão da história que diz respeito aos objetos tratados - história natural e história civil - e, ainda, uma divisão em relação à forma de organização desses objetos - história narrativa e história descritiva -. Nas Instituições, ele subdivide a história em narrativa e descritiva e, nas Lições $^{52}$, relaciona a narração à história civil ou política e a descrição à história natural ${ }^{53}$. A lógica desse desdobramento é a mesma daquela aplicada por Bacon, porém, Ferguson estabelece outros critérios para diferenciar esses dois tipos de história. Em um momento, trabalha com noções de coexistência ou sucessão: enquanto a história descritiva ou natural trabalha com "particulares coexistentes, tal como na descrição de minerais, plantas e animais" (Ferguson, Of History and its Appropriate Stile, 2006, p. 19), a história narrativa ou civil "é uma relação detalhada de eventos sucessivos, tal como na origem, progresso e ruína de transações passadas" (Ferguson, Of History and its Appropriate Stile, 2006, p. 20); em outro, a diferença diz respeito à uniformidade ou variedade: “A história descritiva deve igualmente compreender as descrições de todas as operações que são tão uniformes que sendo descritas uma vez são suficientemente conhecidas e não fornecem qualquer assunto para uma narração posterior. A história narrativa é, em grande medida, apropriada às questões humanas. A série de eventos é variável na vida de cada homem particular e na história das transações particulares e na ascensão, progresso e ruína de cada Estado

\footnotetext{
52 As "Lectures" de Ferguson não publicadas se encontram na Universidade de Edimburgo. Parte delas foram transcritas por David Kettler (Adam Ferguson's Moral Philosophy Lectures, Notes on Lecture Notes from 1775-1785, Lectures 1-34; 85-103). Há também alguns trechos em Ferguson, A. The Manuscripts of Adam Ferguson. Ed. Vincenzo Merolle. London: Pickering \& Chatto, 2006.

${ }^{53}$ Lectures, I, f. 19, apud Ferguson, A. The Manuscripts of Adam Ferguson. Ed. Vincenzo Merolle. London: Pickering \& Chatto, 2006, p. 28, nota 3.
} 
particular" ${ }^{\prime 54}$. Em Ferguson, a sucessão e a variedade das ações humanas são fundamentais para distinguir a história civil da história natural ${ }^{55}$, essa que trata do que é uniforme e repetitivo nas operações da natureza.

Ora, a diferença fundamental da subdivisão da história de Ferguson está na consideração de que a história descritiva ou natural trabalha com operações uniformes, pressupondo claramente que as obras da natureza tenham algum princípio de uniformidade que lhes dê unidade. Fenômenos que se repetem na variedade da natureza serão classificados e ordenados pelo historiador natural formando assim sua ciência. É certo que Bacon não concebe a história natural como um empilhamento de uma diversidade de fenômenos, porém, a classificação e ordenação são dadas sobretudo metodologicamente, ou seja, o entendimento auxilia a memória na coleção dos dados, valendo-se particularmente de experimentos.

Em Ferguson, a história natural é possível antes de tudo porque há uma unidade na criação natural que faz com que a natureza obedeça a leis naturais uniformes ${ }^{56}$. Na verdade, nosso autor considera que as operações da natureza são uniformes porque são regidas por leis regulares tal como expressa pela regra de raciocínio de Newton:

[...] Aos mesmos efeitos naturais temos de atribuir as mesmas causas, tanto quanto possível. Como acontece com a respiração num homem e num animal, a queda de pedras na Europa e na América, a luz de nosso fogo culinário e do sol, a reflexão da luz na terra e nos planetas (Newton, 2012, vol. II, p. 185, grifos do autor).

Assim, operações de minerais, plantas ou animais, seja na Europa ou na América, "sendo descritas uma vez são suficientemente conhecidas e não fornecem qualquer assunto para uma narração posterior" ${ }^{\text {"57 }}$. Isso porque a história natural é a descrição de operações uniformes temporalmente, as mesmas leis que operaram no passado operam no presente, e espacialmente, ou seja, operam de forma uniforme em todos os lugares ("na Europa e na América"). Ora, é exatamente essa regularidade que

\footnotetext{
${ }^{54}$ Lectures, I, f. 19, apud Ferguson, A. The Manuscripts of Adam Ferguson. Ed. Vincenzo Merolle. London: Pickering \& Chatto, 2006, p. 28, nota 3.

${ }^{55}$ Bacon estava ciente do caráter sucessivo e variado das ações humanas quando divide a história em narrativa e indutiva, esta para tratar da história natural e aquela da história civil. Uma das subclassificações dos Memoriais (história civil), por exemplo, dá conta das "anotações de sequencias de eventos e ações nus" (Bacon, 2007, p. 118).

${ }^{56}$ Esse princípio é encontrado também em Hume: “[...] Se fosse a razão, ela o faria com base no princípio de que os casos de que não tivemos experiência devem se assemelhar aos casos que tivemos experiência, e de que o curso da natureza continua sempre uniformemente o mesmo" (Hume, 2009, pp. 117-118, grifos do autor).

${ }^{57}$ Lectures, I, f. 19, apud Ferguson, A. The Manuscripts of Adam Ferguson. Ed. Vincenzo Merolle. London: Pickering \& Chatto, 2006, p. 28, nota 3.
} 
orienta a experiência (testemunho) e garante a classificação dos fenômenos da natureza em história natural.

No entanto, os homens não são somente capazes de reconhecer essa uniformidade da natureza, são eles próprios partes dessa unidade da criação e portanto regidos por leis naturais, as leis da natureza humana, igualmente uniformes ${ }^{58}$ e também passíveis de história natural; mais ainda, para nosso autor, tudo que no homem está inscrito em sua natureza e, consequentemente, apresenta uniformidade e fixidez, pode ser descrito, inclusive a própria sociedade.

Como vimos no capítulo anterior, na filosofia fergusoniana a sociabilidade é uma disposição natural e figura entre as leis da mente - a lei de sociedade: "a predisposição mista à amizade e à inimizade, o uso da razão, a linguagem e os sons articulados, a figura e a postura ereta de seu corpo, tudo isso tem de ser considerado como atributos de sua natureza que devem entrar em sua descrição, assim como, na história natural dos diferentes animais, tem lugar a descrição de asas, membros e patas, além de qualidades como ferocidade, agilidade e vigilância" (Ferguson, 2019, pp. 29-30). Do mesmo modo que dizemos que a juba ou a asa são atributos da natureza do leão e da águia, a sociabilidade é um atributo da natureza dos seres humanos, quer dizer, se a asa e a juba obedecem a leis naturais - seu tamanho, sua utilidade etc. são dados de modo uniforme e fixo pela natureza -, a sociedade é igualmente regida por certos princípios naturais, ainda que mais difíceis de serem estabelecidos, devido à grande variedade das produções e realizações humanas. É justamente por causa dessa grande variedade que, de modo geral, a história civil ou narrativa é a princípio o tipo de história mais apropriada para as ações ou eventos humanos. Todavia, por trás da variedade circunstancial das histórias particulares de cada povo, é possível encontrar traços comuns a todas elas. Hume ilustrou bem essa regra da seguinte forma: “[...] se supões que um dado tenha uma propensão qualquer, por menor que seja, para um lado particular, essa propensão, ainda que não apareça em algumas jogadas, certamente prevalecerá num número maior delas, e fará a balança pender inteiramente para aquele lado" (Hume, 2011, p. 83). Isso quer dizer que a aparente contingência de poucas jogadas do dado pode ser desfeita quando se analisa um maior número delas. O mesmo pode ser aplicado aos eventos da sociedade humana: se

\footnotetext{
${ }^{58}$ De novo Hume: “A humanidade é tão semelhante, em todas as épocas e lugares, que, sob esse aspecto, a história nada tem de novo ou estranho a nos oferecer. Seu principal uso é apenas revelar os princípios constantes e universais da natureza humana, mostrando os homens nas mais variadas circunstâncias e situações, e provendo-nos os materiais a partir dos quais podemos ordenar nossas observações e familiarizar-nos com os móveis normais da ação e do comportamento humano" (Hume, 2008, p. 123, grifo nosso).
} 
analisarmos uma ou outra história particular, encontraremos somente uma série de fatos aparentemente ocasionais, porém, quando comparamos diversas narrativas, passamos a ver fatos comuns, regularidades que se repetem a despeito da variedade dos eventos.

Dito isso, podemos pensar que tipo de história é aplicável à sociedade no Ensaio: narrativa (história civil) ou descritiva (história natural)? Ou ainda: a sociedade de maneira geral é um objeto de conhecimento particular e variável ou coexistente e uniforme? É certo que o tipo de abordagem que Ferguson propõe não pode ser verdadeiramente particular e narrativo, no sentido que não se trata de uma investigação de fatos singulares desse ou daquele povo, mas sim da história de todos os povos, daquilo que eles têm em comum. O que torna possível uma história descritiva da sociedade, o que dá a ela uniformidade, na filosofia de Ferguson, é a sociabilidade natural. Porque a sociedade é a situação para a qual o homem é naturalmente constituído, todos os relatos, todas as histórias particulares das nações, "representam o gênero humano reunido em bandos ou em companhia".

Relatos de todas as épocas e de todas as partes da terra concordam em representar o gênero humano reunido em bandos ou em companhia e o indivíduo ligado por afeto a um grupo, ao mesmo tempo que em oposição a outro, dedicado ao exercício da memória e da antevisão, inclinado a comunicar os próprios sentimentos e a perscrutar os dos outros. Parece que encontramos aí um solo no qual é possível fundar nossos raciocínios sobre o homem (Ferguson, 2019, p. 29).

Com a história natural da sociedade, Ferguson pode equiparar as histórias das nações do passado (relatos antigos) com os relatos que se tem disponível na modernidade das diversas nações espalhadas pelo globo, a fim de compará-las. Segundo Christopher Berry (2013), "a história natural dá aos escoceses uma ferramenta poderosa para entender as sociedades sincronicamente (holisticamente) e arranjando-as em um padrão diacrônico" (p. 49).

\section{II.ii. História natural contra história hipotética de Rousseau}

A história natural da sociedade de Ferguson, como dissemos, não pode ser narrativa, pois não se trata de reconstituir um acontecimento singular do passado, mas é, da perspectiva de nosso autor, construída a partir de fatos. Ferguson "evocou as práticas 
metodológicas da história natural" para criticar o uso de hipóteses na investigação sobre o homem e a sociedade, "argumentando que nossas noções acerca da natureza humana deveriam ser baseadas somente nos registros históricos” (Wood, 1996, p. 205).

Ora, se estamos lidando com uma história natural da sociedade, deve-se proceder da mesma forma como procede o historiador natural, o qual, a partir de observação, descreve e classifica os fatos obtidos. Quando se trata de uma espécie animal qualquer, o historiador descreve o que há de uniforme na observação de vários de seus exemplares, considerando que "suas disposições e instintos" são características próprias da espécie e que estão originalmente presentes em cada indivíduo. Não deveria ser diferente no caso da espécie humana:

O historiador da natureza reconhece que sua obrigação é coletar fatos, não oferecer conjecturas. Quando considera uma espécie animal em particular, supõe que as disposições e os instintos que encontra são tais como os originais, e que o modo de vida de hoje é o desdobramento de uma destinação inicial. Está ciente de que seu conhecimento do sistema do mundo consiste numa coleção de fatos, ou, quando muito, em preceitos gerais derivados de observações e experimentos particulares. É apenas no que the diz respeito, em questões a um só tempo mais importantes e mais fáceis de decidir, que substitui a realidade por hipóteses e confunde as províncias da imaginação e da razão, da poesia e da ciência (Ferguson, 2019, pp. 28-29, grifo nosso) ${ }^{59}$.

A insistência de Ferguson na fonte factual de seu método nos mostra sua oposição com a metodologia de Rousseau em seu Discurso sobre a desigualdade entre os homens. Observemos, pois, o que o genebrino diz de seu próprio método:

Comecemos, pois, por descartar todos os fatos, pois eles não se prendem à questão. Não se devem tomar as pesquisas que se podem realizar sobre esse assunto por verdades históricas, mas somente por raciocínios hipotéticos e condicionais, mais apropriados para esclarecer a natureza das coisas do que para lhes mostrar a verdadeira origem, e semelhantes aos que fazem, todos os dias, os nossos físicos sobre a formação do mundo. [...] Eis o que me perguntam e o que me proponho a examinar neste Discurso. Interessado meu assunto ao homem em geral, tratarei de usar uma linguagem conveniente a todas as nações, ou melhor, esquecendo os tempos e os lugares, para pensar apenas nos homens a quem falo, imaginar-me-ei no Liceu de Atenas, repetindo as lições de meus mestres, tendo

\footnotetext{
${ }^{59}$ Comparar com Rousseau: "O mais útil e menos avançado de todos os conhecimentos humanos pareceme ser o do homem, e ouso dizer que a simples inscrição do templo de Delfos continha um preceito mais importante e mais difícil do que todos os grossos livros dos moralistas” (Rousseau, 2002, p. 149).
} 
os Platões e os Xenócrates como juízes e o gênero humano como auditório. (Rousseau, 2002, pp. 161-162)

A diferença que se constata entre o método investigativo da sociedade dos dois filósofos é sobretudo consequência de divergências muito importantes quanto aos princípios da natureza humana. Quando Rousseau distingue a "origem verdadeira" da "natureza das coisas", ele mostra que não se preocupará com a origem verdadeiramente factual da sociedade; há uma primazia da gênese em detrimento da história real (Binoche, 2013, p. 96). O ponto central da divergência entre os dois filósofos é, portanto, a origem da sociedade: enquanto que para Ferguson a sociedade não teve um início, porque sempre existiu (na verdade, todos os testemunhos que temos à nossa disposição tratam os indivíduos reunidos em grupo, então não estamos autorizados a conjecturar uma situação diferente dessa), para Rousseau a sociedade teve sim um início, uma gênese, ela foi fundada por meio de um pacto. Segundo o genebrino, há um estado natural, anterior à sociedade, que é um estado pré-histórico: Rousseau não poderia realmente usar fatos (testemunhos) como fonte para pensá-lo, e esse não é realmente o caso; como ele mesmo diz: “[..] um estado que já não existe, que talvez não tenha existido, que provavelmente jamais existirá" (Rousseau, 2002, p. 151). Portanto, resta o recurso à hipótese (a história hipotética), que se baseia num processo racional de investigação ${ }^{60}$.

De modo contrário, em Ferguson, não há um período anterior à sociedade, pois essa é um dos "atributos de sua natureza" (Ferguson, 2019, p. 30) e, portanto, coetânea à própria espécie humana. A aplicação do método da história natural em sua investigação tem por pressuposto que os homens, como os demais animais, têm as mesmas disposições e instintos que tinham originalmente: deve haver uma uniformidade nos princípios da natureza humana - as mesmas leis que regem a natureza humana no passado devem reger no presente - para que o mecanismo de comparação e descrição possa operar ${ }^{61}$. Se, como para Rousseau, houvesse uma descontinuidade entre o estado de natureza e o estado de sociedade, não seria possível elaborar uma história da sociedade tal como pensada por

\footnotetext{
60 "Confesso que, como os acontecimentos que tenho de descrever podem ter sucedido de várias maneiras, só por conjecturas posso determinar-me pela escolha" (Rousseau, Discurso sobre as ciências e as artes, 2002, p. 200). Ferguson está interessado no que aconteceu, na história real, não no que poderia ter acontecido; é nesse sentido que ele diz que "é provável que aqui, como em muitos outros casos, não estejamos qualificados para oferecer, a partir do nosso suposto conhecimento de causas, um prognóstico de efeitos, ou mesmo para determinar quais teriam sido as propriedades e operações da nossa própria natureza fora das circunstâncias em que nos encontramos [...]" (Ferguson, 2019, p. 121).

${ }^{61}$ Mesmo o uso que nosso autor faz das histórias particulares e dos trabalhos etnográficos pressupõe uma uniformidade na natureza humana, pois somente admitindo que haja um paralelo entre, por exemplo, um indivíduo dos primórdios de Atenas e um "bárbaro" da Ásia moderna, é que podemos utilizá-los como fonte comparativa de informação.
} 
Ferguson: sua história é um processo contínuo de progresso da espécie, desde as formas sociais mais simples, os selvagens, até os mais complexos arranjos institucionais e políticos das nações modernas. Nesses dois extremos, a espécie é a mesma e os indivíduos têm as mesmas características naturais, havendo apenas uma complexificação circunstancial das formas de vida ${ }^{62}$. É por isso que Ferguson afirma que os homens nunca deixaram seu estado de natureza:

Portanto, se nos for posta a questão "Onde se encontra o estado de natureza?", responderemos: aqui, não importa se na ilha da Grã-Bretanha, no Cabo da Boa Esperança ou no Estreito de Magalhães. Enquanto o homem continuar a empregar seus talentos e a interferir nos objetos à sua volta, todas as situações serão igualmente naturais (Ferguson, 2019, p. 36).

Ou seja, os povos selvagens não estão mais próximos a um estado natural do que os habitantes de nações civilizadas, pois um "princípio de progressão" e um "desejo de perfeição" (Ferguson, 2019, p. 36) estão presentes em ambos. Com isso, nosso autor quer desfazer uma oposição que há em Rousseau entre o que é natural e o que é artificial nos homens: "Comecei alguns raciocínios, arrisquei algumas conjecturas, não tanto com a esperança de resolver a questão quanto com a intenção de esclarecê-la e reduzi-la ao seu verdadeiro estado [...]. Pois não é de pouca monta o empreendimento de distinguir o que há de original e de artificial na natureza atual do homem [...]” (Rousseau, 2002, p.151). Para Ferguson, em sentido oposto, “a própria arte é natural ao homem” (Ferguson, 2019, p. 239), sendo assim, não podemos distinguir nele o que é natural ou original do que é artificial: "o homem é, em certa medida, o artífice de sua própria estrutura" (Ferguson, 2019, p. 34).

Em não havendo um período pré-social ou pré-histórico, Ferguson pode reconstituir metodologicamente os primórdios da sociedade usando como material não especulações filosóficas, mas as narrativas históricas e os relatos de viagens ${ }^{63}$. Todo esse material será sobreposto ${ }^{64}$ para que se possa fazer generalizações de experiências

\footnotetext{
${ }^{62}$ Segundo Claude Gautier (2011): “O estado de natureza é, então, aquele de sociedade; ele é aqui e agora como sempre foi. Tipo de neutralização paradoxal da temporalidade que conjuga em uma só e mesma realidade aquilo que foi e aquilo que é a natureza humana. Não fazemos mais que recuperar o postulado de constância da natureza em sua disposição à transformação que permite a submissão ao escrutínio científico, quer dizer, de se fazer uma história" (pp. 22-23, grifo do autor).

63 A bem da verdade é que Rousseau também utiliza essas fontes; porém, o genebrino as utiliza, principalmente as narrativas e relatos de viagens, para especular sobre a natureza humana. Quando faz a genealogia da sociedade, esses fatos são colocados de lado.

64 “[...] a história natural se desdobra numa duração e num espaço abstrato, obtidos indutivamente por superposição das séries históricas reais" (Binoche, 2013, p. 106).
} 
semelhantes entre os diversos povos. Porém, dizer que a história natural da sociedade é fundamentada em fatos empíricos não faz dela uma história real: ela é propriamente uma história indiciária, baseada em "dados históricos” (Binoche, 2013, p. 105).

\section{II.iii. A questão da fonte ou a história factual}

Ferguson abre a seção sobre a história das nações rudes, os primórdios da sociedade, comparando a antiguidade de vários povos, como a dos gregos, dos romanos, dos gauleses e dos germânicos, inclusive recorrendo à história sacra. É que para ele a história da sociedade (história natural), da mesma forma que as histórias particulares (história civil), só pode ser traçada a posteriori: “[...] quem poderia, por mera conjectura, supor que o selvagem nu seria um janota e um jogador? Que teria orgulho ou vaidade, mesmo sem possuir distinções de título ou de fortuna? E que a sua maior preocupação seria adornar-se a si mesmo e se distrair?" É por isso que "é provável que aqui, como em muitos outros casos, não estejamos qualificados para oferecer, a partir do nosso suposto conhecimento de causas, um prognóstico de efeitos, ou mesmo para determinar quais teriam sido as propriedades e operações da nossa própria natureza fora das circunstâncias em que nos encontramos" (Ferguson, 2019, p. 121). A história da sociedade, como dissemos, é elaborada através de um processo indutivo, em que material historiográfico é a fontes de generalizações.

No entanto, o recurso à historiografia, como uma das fontes factuais do método empirista de investigação, não pode ser dar às cegas, pois "as antiguidade domésticas de cada nação", "no mais das vezes", são "meras conjecturas ou ficções de épocas subsequentes, e mesmo que de início tenham a aparência de verdade, variam muito com a imaginação dos que as transmitem" (Ferguson, 2019, p. 122). Ferguson compartilhou com muitos de seus contemporâneos certa desconfiança das narrativas legadas pelos historiadores, principalmente quando se trata de eras longínquas e sobre as quais há muita fabulação.

Hume, para quem a história era fonte de "experimentos pelos quais o político e o filósofo da moral fixam os princípios de sua ciência" (Hume, 2004, p. 123), refletiu mesmo sobre as condições de possibilidade dessa disciplina. Para ele, a evidência das narrativas históricas só pode ser pensada enquanto probabilidade; ou seja, sobre elas só podemos alcançar conclusões que nos indicam que tal ou qual evento seja mais ou menos provável de ter ocorrido. Nossa própria experiência do curso dos eventos humanos pode 
ser um guia importante para que possamos julgar a veracidade de certos relatos: "se um viajante, retornando de um país distante, traz-nos notícias de homens completamente diferentes de todos os que conhecemos, homens inteiramente desprovidos de avareza, ambição ou predisposição à vingança, que não sentem outros prazeres que os da amizade, generosidade e espírito público, essas coisas nos levariam imediatamente a detectar a falsidade e acusá-lo de mentiroso" (Hume, 2004, p. 123-124), pois seu relato é contrário ao que costumamos ver na nossa convivência diária com os homens. No entanto, a questão não é tão simples, como Hume se esforça em enfatizar, pois esse guia, qual seja, a nossa própria experiência, é falível, dado que alguns acontecimentos "mostram-se mais variáveis e frustram algumas vezes nossas expectativas [...]” (Hume, 2004, p. 155). Portanto, se o fato que nos é apresentado é infalível, ou seja, todas as vezes que ocorreu, ocorreu da mesma maneira, então podemos emitir um juízo mais seguro e crer em sua veracidade; no entanto, se a experiência nos mostra que fatos contrários também ocorreram, devemos sobrepesar "os experimentos opostos, considerando qual lado se apoia no maior número de experimentos, inclinando-se para esse lado com dúvida e hesitação, e, ao formar finalmente um juízo, a evidência não excede o que propriamente se denomina probabilidade" (Hume, 2004, p. 155, grifos do autor).

Assim, para Hume, uma comparação entre diversos eventos, além de um conhecimento da natureza humana no seu curso regular, pode nos ajudar a decidir sobre a maior ou menor probabilidade de verossimilhança de um dado relato. Um exemplo dessa operação nos é apresentado na Investigação sobre o entendimento humano: Tácito "esse excelente historiador", "o maior e mais penetrante gênio, talvez, de toda Antiguidade", em suas Histórias, conta que Vespesiano teria curado "um cego em Alexandria por meio de sua saliva e um coxo com o simples toque de seu pé". Nesse caso, como em qualquer outro exemplo de prodígio ou milagre, devemos dosar nossa experiência com o fato narrado: não há no curso normal da nossa vida, nem na história, muitas experiências que se assemelhem a essa, por isso "devemos dar preferência aos [argumentos] que estão apoiados no maior número de observações passadas" (Hume, 2004, pp. 169-170). Ademais, devemos consultar outros historiadores contemporâneos a Tácito e investigar se eles também narram esse prodígio, e até mesmo se o narram de igual maneira, a fim de encontrarmos possíveis contradições que possam invalidar sua veracidade.

O método que Ferguson empreendeu para tonar factível (científico) seu recurso à história foi, igualmente, a comparação das diversas narrativas e o recurso aos princípios da natureza humana. Por exemplo, quando analisa a origem das nações em geral, o autor 
diz que "o passado de um povo, por mais que se diferencie do de outros e por mais camuflado que esteja, contém sempre alguma informação a respeito dessa questão", qual seja, "de um progresso lento e gradativo" (Ferguson, 2019, p. 119). Isso significa que por mais que haja floreios e até fabulações nessas narrativas, comparando-as entre si podemos depreender certos padrões uniformes, fatos nos quais podemos nos fiar. É que, na verdade, tanto Ferguson quanto Hume via na uniformidade da natureza humana um guia seguro para a história: no meio do emaranhado de eventos ocasionais, é possível distinguir traços humanos constantes que são a expressão mesma dessa uniformidade.

Além disso, diz Ferguson, devemos ser cautelosos para não considerarmos nosso tempo como referência para a investigação do passado; "é difícil”, mesmo para "homens de gênio e habilidades incomuns" (Ferguson, 2019, p. 125), "transmitir, sob os nomes utilizados no estado atual da sociedade, uma justa apreensão do que teria sido o gênero humano em situações tão díspares e em épocas tão distantes daquela em que eles se encontram" (Ferguson, 2019, p. 126). Um exemplo bem-sucedido é a descrição que Hume faz, em sua História da Inglaterra, de como em outra época não só um bandido foi capaz de penetrar na festa do rei, como o próprio monarca participou da tentativa de expulsá-lo, sendo morto na ocasião ${ }^{65}$. Esse ocorrido não poderia ser narrado dessa forma se tomássemos como referência a enorme distinção que há entre monarcas e súditos no período em que fora escrita. Ainda que faça tal elogio à História da Inglaterra de Hume, nosso autor não esconde sua predileção pelos historiadores antigos:

Porém, graças aos historiadores, gregos e romanos, temos não só as mais autênticas e instrutivas, como também as mais interessantes representações das tribos de que descendemos. Esses sublimes e capazes autores compreenderam a natureza humana e souberam identificar suas feições e exibir seus caracteres em situações bastante diferentes daquela em que se encontravam. Os primeiros historiadores da Europa moderna não fizeram jus a eles. Foram no geral criados para a profissão de monges e, confinados a uma vida monástica, dedicaram-se exclusivamente a registrar o que gostavam de chamar de fatos, não se importaram com a destruição de muitas produções de gênio e mostraram-se incapazes, seja pelos assuntos que escolheram, seja pelo estilo das suas composições, de representar o ativo espírito do gênero humano nas diferentes condições nas quais ele se encontra (Ferguson, 2019, pp. 124-125).

\footnotetext{
65 “As dignidades e mesmo os ofícios da sociedade civil eram conhecidos na Europa, muitos anos atrás, pelas mesmas denominações do presente; mas a história da Inglaterra mostra que um criminoso, que subsistia pelo roubo, participou de um solene banquete oferecido pelo rei aos seus cortesãos. Quando foi descoberto por Sua Majestade, que se ergueu para expulsá-lo, o indigno convidado se recusou a partir; seguiu-se uma disputa, e o rei foi morto" (Ferguson, 2019, p. 126).
} 
É que, na verdade, como afirma J. G. Pocock (1999), os historiadores antigos, ou a narrativa clássica, era ainda "um modelo exemplar", "uma autoridade extraordinária na cultura neoclássica até a Era das Revoluções” (p. 10). Hume, da mesma forma, espelha-se nos escritores romanos para escrever a sua História da Inglaterra e recheia, mesmo seus escritos filosóficos, de exemplos tirados das narrativas antigas.

Outra fonte importante de material factual para a descrição dos primórdios da sociedade são os trabalhos etnográficos, muitos oriundos da descoberta de povos na América e na Ásia ${ }^{66}$, compilados em histórias naturais ou relatos de viagens ${ }^{67}$. Esse material, além de nos permitir comparar com a historiografia disponível, a fim de distinguirmos o que nela é mera conjectura ou ficção do que é propriamente verídico, igualmente "serviu de provisão de informação factual sobre os vários modos de vida da espécie humana em diferentes partes do globo" (Wood, 1996, p. 204). É que esses povos, estando ainda num estágio rude de desenvolvimento, podem fornecer, "como num espelho", informações sobre como as nações civilizadas foram nos seus primórdios, da mesma forma como os romanos, já num estágio mais avançado, devem ter visto algo semelhante aos seus "próprios ancestrais" quando chegaram à Grã-Bretanha:

Pode ser que os romanos tenham encontrado uma imagem dos seus ancestrais nas representações que fizeram dos nossos. E se algum dia um clã árabe se tornar uma nação civilizada ou uma nação americana se livrar do veneno inoculado pelos comerciantes da Europa, é possível que os relatos e as descrições de viajantes que temos sobre eles forneçam a esse povo a melhor explicação das suas origens (Ferguson, 2019, p. 127).

\footnotetext{
${ }^{66}$ Ferguson traça uma história geográfica das nações rudes de sua época: "De uma extremidade a outra da América, do extremo oeste de Kamschatka ao Rio Olga, do Mar do Norte aos confins da China, da Índia e da Pérsia, do Mar Cáspio ao Vermelho, com poucas exceções, e deste último, através do continente, às praias da costa ocidental africana, encontram-se por toda parte nações que denominamos bárbaras ou selvagens" (Ferguson, 2019, p. 128).

${ }^{67}$ Ferguson cita, dentre outros, Charlevoix (padre jesuíta, viajante e historiador, escreveu diversas histórias etnográficas, principalmente a Histoire et description générale de la Nouvelle France), Lafitau (missionário jesuíta, etnologista e naturalista, escreveu Moeurs des sauvages americaines comparée aux moeurs de premiers temps), Cadwallader Colden (médico e naturalista, escreveu The History of the Five Indian Nations Depending on the Province of New-York in America), Jean Chardin (viajante e escritor, escreveu Voyages de monsieur le chevalier Chardin en Perse et autres lieux de l'Orient), Rubruquis (missionário franciscano, publicou em 1253 Itinerarium fratris Willielmi de Rubruquis de ordine fratrum Minorum sobre sua viagem à Mongólia) e Peter Kolbe (prefeito de Amsterdã, escreveu extensa obra de história natural a partir de sua viagem ao Cabo da Boa Esperança, Description of the Cape of Good Hope).
} 


\section{II.iv. A história da sociedade como história da espécie}

Nas Instituições, Ferguson diz que "a história do homem contém ou fatos conforme ocorrem em uma visão geral da espécie ou conforme ocorrem para o indivíduo, quando relembra o que se passa em sua própria mente" (Ferguson, Instituições, 2019, p. 389). Nessa abordagem, Ferguson se refere textualmente a Buffon para corroborar a subdivisão da história natural do homem em história da espécie e história do indivíduo.

Tudo que dissemos até aqui da geração do homem, de sua formação, de seu desenvolvimento, de seu estado nos diferentes anos de sua vida, de seus sentidos e estrutura de seu corpo, aquilo que conhecemos pela dissecção anatômica, formam apenas a história do indivíduo, aquela da espécie demanda um detalhe particular, cujos fatos principais só poderiam ser obtidos das variedades que pode ser encontrada entre os homens de diferentes climas (Buffon, 1984, p. 140).

O naturalista faz uma distinção fundamental entre a história natural dos homens e a dos demais animais: nas bestas, a história do indivíduo não difere da história da espécie, pois cada um age de modo muito semelhante a todos os outros da mesma espécie, quer dizer, há uma uniformidade tão grande que "a ordem de suas ações é comum a toda a espécie" (Buffon, 1833, tomo VIII, p. 359). Dessa forma, nos animais, a descrição de um indivíduo corresponde à descrição da espécie como um todo: a história do indivíduo e a história da espécie são uma e mesma coisa. Quando se trata dos homens, temos, por um lado, características muito semelhantes a todos os seres da espécie, como sua geração, formação e desenvolvimento, que são compreendidas na história do indivíduo; por outro lado, ainda que uma única espécie ${ }^{68}$, o gênero humano apresenta uma grande variedade, em sua cor e compleição, em suas maneiras e costumes, em sua forma de vida e alimentação, que fazem parte da história da espécie. Na verdade, há mesmo uma grande diversidade nas "produções e realizações" (Buffon, 1833, tomo VIII, p. 359) de cada indivíduo, isso porque os homens são capazes de inventar e aperfeiçoar (Buffon, 1984, p. 134), características que não estão presentes nos animais brutos ${ }^{69}$.

\footnotetext{
68 “[...] Tudo contribui para provar que o gênero humano não é composto de espécies essencialmente diferentes entre si, muito ao contrário: há originalmente somente uma espécie de homens, que tendo se multiplicado e reproduzido sobre toda a superfície da terra, sofreu diferentes mudanças pela influência do clima, pela diferença na alimentação, pela maneira de viver, pelas doenças epidêmicas e também pela mistura variada ao infinito de indivíduos mais ou menos semelhantes [...]" (Buffon, 1984, pp. 142-143). 69 "Por que há tanta diversidade e variedade em nossas produções e em nossas realizações? Por que a imitação servil nos custa mais que um novo plano? É porque nossa alma é única e independente de qualquer outra, porque não temos nada em comum com nossa espécie além da matéria de nosso corpo e somente por causa dessa que somos parecidos com os animais" (Buffon, 1833, tomo VIII, p. 359).
} 
No artigo Variedades da espécie humana, em que Buffon trata da história natural da espécie, lê-se que seus "principais fatos" só podem ser derivados "das variedades encontradas nos habitantes de diferentes climas" (Buffon, 1984, p. 140); quer dizer: a variedade dos povos de diferentes climas é propriamente o objeto de descrição e investigação da história da espécie humana; "trata-se de ordenar a multiplicidade dos fatos e de descobrir constantes em uma profusão de variáveis" (Duchet, 1995, p. 249). A influência do clima é fundamental pois sua espécie é a única dentre os seres vivos que pode "subsistir, se multiplicar por toda parte, e se adequar às influências de todos os climas da terra" (Buffon, 1984, p. 209).

Desde que o homem começou a mudar de céu e se dispersou por diversos climas, sua natureza sofreu muitas alterações: nas regiões temperadas, que supomos vizinhas de seu lugar de origem, essas alterações foram pequenas; porém, elas aumentam à medida que dali ele se distanciou. Depois de transcorridos muitos séculos, continentes atravessados e gerações já degeneradas, por influência dos diferentes solos, o homem acabou por se habituar aos climas extremos e povoou as areias do sul e os gelos do norte [...] (Buffon, 1984, p. 223).

Assim, original das regiões temperadas, o homem se dispersou e se diversificou por um processo de degeneração de seu modelo ou "protótipo geral" (Buffon, 1984, p. 188). Para Buffon, exatamente porque a espécie humana é única, sua variedade se apresenta como uma variedade de raças ${ }^{70}$. É desse modo que a história natural da espécie trata de determinar, ou melhor, de descrever as diferentes raças humanas, ao mesmo tempo em que se investigam suas causas. Esse estudo se orienta geograficamente, dado que os diferentes climas se relacionam com as diferentes regiões ${ }^{71}$.

O que determina cada raça são seus traços físicos comuns - forma, tamanho e cor de pele e cabelo - e morais - inclinações e maneiras ${ }^{72}$ : é que cada povo obedece a determinações físicas e morais. Para Buffon, de modo geral, são justamente esses aspectos

\footnotetext{
${ }^{70}$ Isso não significa que não haja variedade dentro de cada raça, mas ela serve de categoria para organizar a multiplicidade de tipos. Segundo Michèle Duchet (1995), "o conceito de raça é então intermediário entre a espécie, para a qual Buffon deu inicialmente uma definição puramente biológica, e as variedades da espécie, que são uma realidade antropológica" (Duchet, 1995, p. 271).

${ }^{71}$ Buffon divide o globo terrestre em quatro regiões principais: Europa, Ásia, África e América.

72 "Os Samoiedos, os habitantes de Zembla e da Borandia, os Lapões, os Groenlandeses e até mesmo os selvagens ao norte dos esquimós são todos homens da mesma espécie, uma vez que se assemelham na forma, no tamanho, na cor, na moral e até menos na estranheza dos costumes" (Buffon, 1827, tomo XII, p. 198).
} 
os mais marcantes na determinação da variedade: "a primeira e mais marcante é a cor, a segunda é a forma e o tamanho, e a terceira a disposição (naturel)" (Buffon, 1984, p. 140).

Ainda que Buffon aponte para o fato de que a causa das variações decorram da concorrência de causas do meio geográfico e do meio social, o principal motivo da variedade que se observa na espécie humana advém dos costumes e do modo de vida de cada povo. Dito de outra forma: a sociedade humana tem papel decisivo na distinção dos povos.

Supondo dois povos diferentes sob o mesmo clima, pode-se crer que os homens de uma nação selvagem serão mais morenos, mais feios, de menor estatura e mais enrugados do que aqueles de uma nação policiada (Buffon, 1827, tomo XII, p. 268).

A sociedade é, portanto, um artigo fundamental da história natural do homem; segundo Buffon, "o homem só é homem porque soube se reunir ao homem” (Buffon, 1984, p. 151). A sociabilidade é para ele natural não somente porque é um fato - "em todo estado, em todas as situações e sobre todos os climas ele [o homem] tende igualmente à sociedade", mas principalmente por ser um traço da natureza humana, ou seja, está inscrita na "essência mesma da espécie" (Buffon, 1984, p. 157). Porque nascem "nus, fracos e incapazes de movimento" (Buffon, 1984, p. 151), os seres humanos dependem de um cuidado exterior, primeiramente dos pais e depois da sociedade de modo geral. É por esse motivo que um estado de natureza, um estado em que não haja qualquer união entre homens, nem mesmo em famílias, não passa de conjectura. Ora, "o estado de pura natureza é conhecido; é o selvagem no deserto, mas vivendo em família, conhecendo seus filhos, que também o conhece, usando a palavra e se fazendo entender" (Buffon, 1984, p. 156).

Como dissemos, a espécie humana se espalhou pelos quatro cantos da terra e se subdividiu em diferentes raças a partir de um "modelo ou unidade" cuja origem é a zona temperada; ou seja, "o clima mais temperado" é o "meio humano por excelência, aquele que oferece à espécie as melhores condições de vida e de desenvolvimento" (Duchet, 1995, p. 255, grifo da autora). Porque nesse meio os homens têm melhores condições de fazer uso de sua razão (são mais capazes de inventar e de aperfeiçoar, ou seja, de evoluir) é que sua organização social tende a ser mais civilizada e, em sentido contrário, quanto mais nos afastamos dessa região, mais rudes (degenerados) eles serão. Se o clima influência no modo de vida dos homens, o próprio modo de vida, por sua vez, interfere em outros aspectos da espécie. Segundo Buffon: 
Um povo civilizado que vive com certa facilidade, que está acostumado a uma vida regrada, suave e tranquila, que, pelo cuidado de um bom governo, está a salvo de certa miséria, e não carece dos artigos de primeira necessidade, será, apenas por essa razão, composta de homens mais fortes, mais bonitos e mais bem feitos que uma nação selvagem e independente, onde cada indivíduo, não sendo ajudado pela sociedade, é obrigado a prover sua subsistência, a sofrer alternadamente fome ou os excessos de uma comida muitas vezes ruim, a se consumir ora com trabalho ora com a lassidão, a experimentar os rigores do clima sem poder se abrigar, a agir, em uma palavra, mais como um animal do que como um homem (Buffon, 1827, tomo XII, 268).

O que Buffon está dizendo é que o aperfeiçoamento da espécie está intrinsecamente relacionado ao grau de desenvolvimento da sociedade: mesmo os traços físicos são aperfeiçoados quando se tem uma sociedade civilizada, justamente porque o meio social tem papel determinante nas características que compõem a raça. No que diz respeito à sociedade, ela se desenvolve onde há condições climáticas favoráveis, desde sua forma mais primitiva, os povos selvagens, até a sua perfeição máxima, os povos refinados.

Ora, vemos que descendemos por degraus bastante insensíveis desde as nações mais esclarecidas, mais refinadas até os povos menos industriosos; desses a outros mais rudes, mas ainda sujeitos a reis, a leis; desses homens rudes para os selvagens, que não se assemelham absolutamente, mas entre os quais encontramos tantas nuances diferentes quanto entre os povos refinados; uns formam nações bastante numerosas, sujeitos a chefes; outros, em sociedades menores, estão sujeitos apenas aos costumes; até que finalmente os mais solitários, os mais independentes, não deixam de formar famílias e de se sujeitarem aos seus pais. Um império, um monarca, uma família, um pai, esses são os dois extremos da sociedade: esses extremos também são os limites da natureza (Buffon, 1833, tomo XI, p. 91).

A história humana se passa, portanto, entre os dois extremos da escala da sociedade, entre o selvagem americano do Novo Mundo e o europeu civilizado do Velho (Duchet, 1995, p. 247). Entre o primitivo ("no duplo sentido do termo, porque são 'os mais novos do universo' e ainda no 'estado de pura natureza', no sentido moral e físico"” (Duchet, 1995, p. 248)) e o evoluído: todos os outros estados sociais e todas as variedades da espécie estão circunscritas a esse limite. É por esse motivo que Michèle Duchet (1995) 
afirma que, para Buffon, "a história da espécie e a história das sociedades são uma só" (p. 241, grifo nosso).

Ora, se uma identidade entre história da espécie e história da sociedade já está sugerida na História Natural de Buffon como afirma Duchet, Ferguson, no Ensaio, tornaa explícita. Primeiramente, nosso autor admite a subdivisão de Buffon entre história do indivíduo e história da espécie humana porque emprega igualmente a categoria espécie para se referir ao gênero humano. Na verdade, a espécie não é apenas uma categoria taxonômica, ela é a denominação dos homens enquanto grupo de indivíduos. Mais ainda, o indivíduo - a história do indivíduo - deve ser sempre analisado sob a perspectiva de sua espécie:

Os homens devem ser tomados em grupo, como sempre existiram. A história dos indivíduos é insignificante, comparada aos sentimentos e pensamentos que cada um nutre pela espécie. Por isso, experimentos relativos a esse objeto precisam ser realizados com sociedades inteiras, não com homens individuais (Ferguson, 2019, p. 30).

Ferguson faz da sociabilidade o principal atributo da humanidade, a característica determinante da espécie, e transforma a sociedade, e não "homens singulares", na "unidade de investigação" (Bryson, 1945, p. 44) acerca da natureza humana. Dessa forma, sua determinação da espécie, no Ensaio, é dada por categorias sociais, que são os períodos classificatórios do desenvolvimento das sociedades, em analogia aos períodos da vida humana individual:

Produtos naturais geralmente se formam por graus. Os vegetais brotam de tenras raízes; de embriões crescem os animais. Estes, destinados à ação, diversificam suas atividades conforme aumentam os seus poderes e exibem progressos em tudo o que realizam, inclusive na aquisição de faculdades. No homem, esse progresso vai muito além de outros animais, não apenas no indivíduo, que progride da infância à idade adulta, mas também na espécie, que vai da rudeza à civilização (Ferguson, 2019, p. 27).

Assim, o progresso da espécie é descrito em termos de progresso social: o estado rude ou o estado polido são determinações do desenvolvimento da espécie da mesma maneira como a infância e a idade adulta determina o desenvolvimento do indivíduo.

Em segundo lugar, Ferguson resume a variedade da espécie a uma variedade social: o que importa na sua classificação da diversidade são as constantes no modo de vida, ou seja, são somente os caracteres morais e - não físicos - de cada povo que serão 
descritos e comparados. Assim, os diferentes momentos do progresso social respondem pela diversidade humana não só observada ao redor do globo terrestre, mas igualmente ao longo da história humana.

\section{II.v. O progresso da espécie}

Como foi dito a uniformidade da natureza humana, das leis naturais de maneira geral, é um princípio fundamental para a elaboração de uma história natural do homem. Além disso, nosso autor faz do fato da sociedade "um solo no qual é possível fundar nossos raciocínios sobre o homem” (Ferguson, 2019, p. 29). Isso quer dizer que Ferguson transforma um atributo da natureza humana, a sociabilidade natural, no princípio que organiza a investigação de todos os outros atributos, ou melhor, que contém em si mesmo todos os demais ${ }^{73}$ : a história da sociedade é a própria história da espécie.

Soma-se ainda a ideia de um progresso, que não é visto somente no indivíduo, mas igualmente na própria espécie, e, portanto, na sociedade. Segundo Michel Malherbe (2005), o progresso se torna "uma propriedade natural" (p. 174), natural ao indivíduo e natural à espécie: é o que Ferguson denomina princípio de progressão. Mas o que é esse princípio de progressão? Nos Princípios, Ferguson estabelece que dentre os seres da natureza, uns são estacionários, outros progressivos. "Ser progressivo", segundo Ferguson, significa que esse ser varia ou muda de "um estado a outro" motivado por um “princípio de avanço no próprio indivíduo” (Ferguson, 1792, vol. I, p. 190).

No Ensaio, o progresso da espécie é igualmente dado em analogia ao progresso do próprio indivíduo: "No homem, esse progresso vai muito além de outros animais, não apenas no indivíduo, que progride da infância à idade adulta, mas também na espécie, que vai da rudeza à civilização" (Ferguson, 2019, p. 27). Mais ainda, nesse último, o progresso da espécie é pensado através estágios sociais determinados, os estágios rudes, selvagem e bárbaro, e o estágio polido ou comercial; isso porque, para nosso autor, há uma identidade entre progresso da espécie e história da sociedade.

A história natural foi designada por Ferguson como sendo aquela que trata de particulares uniformes ou coexistentes, enquanto a história factual dá conta dos eventos sucessivos. Ora, a história natural da sociedade, bem como de qualquer outro fenômeno progressivo, embora não aborde circunstâncias coexistentes, pode tratar da enumeração

\footnotetext{
${ }^{73}$ É por esse motivo que a história da sociedade de Ferguson contém a história das nações rudes e a história da política (policy) e das artes, essa que contempla ainda a história da subordinação, das artes e da literatura.
} 
dos próprios degraus "de transição de uma forma ou estado de existência a outro"; nesse sentido, a analogia com o indivíduo é mantida:

Enquanto indivíduos estacionários são descritos através da enumeração de partes coexistentes e de qualidades quiescentes, indivíduos progressivos são caracterizados através da enumeração dos degraus de transição de uma forma ou estado de existência a outro e através do limite ou ponto de aproximação, quer próximo ou remoto, para o qual os movimentos sucessivos de sua natureza são direcionados (Ferguson, 1792, vol. I, p. 191).

Assim, a descrição da qual a sociedade é passível tem como ponto de apoio cada um dos degraus ou estágios de seu progresso, quais sejam, estágios selvagem, bárbaro e polido. Porém, dizer que a sociedade progride não implica necessariamente dizer que ela melhora. Mesmo aqui, Ferguson mantém a analogia com o indivíduo:

A posição de um indivíduo progressivo não deve ser avaliada através de sua condição em qualquer estágio particular de seu progresso, mas através de sua capacidade e destinação para avançar na escala dos seres (Ferguson, 1792, vol. I, p. 191).

Nosso autor aplica o mesmo raciocínio ao progresso da sociedade: as nações não devem ser avaliadas somente sob a perspectiva de seu estágio particular, mas por aquilo que podem ser. A história natural da sociedade descreve, portanto, um processo de "complicação crescente das condições de existência" (Binoche, 2013, p. 100) que deve ser "concebido a partir da perspectiva de uma variação estritamente quantitativa" (Binoche, 2013, p. 99). Nesse processo, as nações progridem e até aperfeiçoam seus modos de vida e suas instituições, mas não necessariamente melhoram ou chegam mais perto de sua destinação, pois essa se expressa justamente na capacidade de progresso, e não num certo modelo de civilização. Dessa forma, Ferguson imprime um ponto de vista neutro em relação a cada momento da história da sociedade: ainda que haja aperfeiçoamento, não se pode julgar o progresso como o desenrolar de um processo de contínua superiorização.

Quando as nações se sucedem umas às outras na carreira das investigações e descobertas, a última é sempre a mais sapiente. Sistemas de ciência formam-se de modo gradual. A história do globo é marcada por gradações, e cada época, uma vez encerrada, lega às que a sucedem um conhecimento aprimorado. Os romanos eram mais sapientes do que os 
gregos; e, nesse sentido, qualquer um dos atuais estudiosos europeus é mais versado que os célebres do passado. Seria por isso superior a eles? (Ferguson, 2019, pp. 62-63)

$\mathrm{Na}$ verdade, mesmo sendo possíveis várias analogias entre o progresso do indivíduo e o progresso da espécie, no caso dos homens, há uma diferença fundamental: as atividades e realizações humanas (para usar um termo anacrônico, a cultura) são transmitidas de um período a outro no progresso da espécie, o que garante às sucessivas gerações um acréscimo de conhecimento.

O estado de natureza relativo à espécie é diferentemente constituído e de extensão diferente. Ele consiste em uma sucessão contínua de uma geração e outra; em realizações progressivas feitas por diferentes eras, comunicadas com adições de era para era, e nos períodos os mais avançados não aparentam ter chegado a nenhum limite necessário (Ferguson, 1792, vol. I, p. 194).

Isso quer dizer que "capacidade" de avanço é a mesma para todas as eras, há apenas uma diferença no acúmulo que cada uma dispõe ${ }^{74}$. Assim, o progresso não é somente lento e gradual - "produtos naturais geralmente se formam por graus" (Ferguson, 2019, p. 27) -, mas a princípio ilimitado; parece não haver limite para a complexificação da sociedade, que é efeito da ação humana historicamente acumulada. No entanto, embora as realizações da humanidade ponham em movimento esse processo, não se pode falar em um desígnio humano no direcionamento da história: “cada passo e cada um de seus movimentos, mesmo nas épocas ditas ilustradas, se dão sem consideração pelo futuro, as nações como que tropeçam em instituições que resultam, na verdade, da ação humana, e não da execução de um desígnio humano" (Ferguson, 2019, p. 182). A história é, na realidade, expressão da natureza humana em sua interação com as circunstâncias externas ao longo do tempo. Nessa interação, ora a força exercida pela natureza, ora aquela exercida pelas circunstâncias parece predominar na determinação do curso do progresso. Um exemplo de determinação circunstancial Ferguson atribui ao clima e à localização geográfica dos povos.

O clima, como o próprio autor explica, não corresponde apenas “aos graus medidos desde o Equador até o polo; tampouco a temperatura do ar depende exatamente

\footnotetext{
74 "Mesmo os esforços mais recentes da invenção humana são prolongamentos de dispositivos utilizados desde o seu estado mais rude, nas épocas primitivas do mundo. As observações e os projetos do silvícola são os primeiros passos no mesmo caminho que será trilhado pelas nações mais avançadas, da construção de casebres e à edificação de palácios, das percepções particulares dos sentidos até as conclusões gerais de ciência" (Ferguson, 2019, pp. 36-37).
} 
da latitude", pois há outras variáveis que influenciam "na composição da estrutura animal", como "as variedades de solo e diferentes localizações" e "a proximidade ou a distância em relação ao mar” (Ferguson, 2019, p. 174) ${ }^{75}$. Há todo um conjunto de causas físicas, que James Dunbar chama de "circunstâncias locais""76, que podem responder por certas diferenças sociais.

$\mathrm{Na}$ verdade, Ferguson abre a seção Da influência do clima e da localização fazendo uma separação entre a história das nações rudes, que é comum a todo o gênero humano e se encontra "em diferentes partes do globo", e a história da sociedade civil, que tem sua morada apenas em "certos lugares da Terra" (Ferguson, 2019, p. 165), qual seja, as zonas temperadas. Assim, ainda "em sua capacidade animal", o homem esteja “qualificado para sobreviver em todos os climas" (Ferguson, 2019, p. 165) ou, ainda que rigorosamente todos os povos estejam sujeitos a progredirem da rudeza à civilização, quando observamos tantos as nações de nosso tempo ou a partir da história, percebemos que esse progresso se restringe àquelas situadas em regiões de clima mais ameno ${ }^{77}$. Isso se dá porque o clima não somente exerce influência sobre as características físicas dos povos, mas inclusive sobre seu gênio, tornando-os mais ou menos moderados ou fervorosos, mais ou menos inclinados à amizade ou à animosidade, às ciências ou às artes etc.; apesar de que "não poderemos explicar a atuação dessas influências antes de ter compreendido algo que provavelmente nunca entenderemos, a saber, a estrutura dos órgãos mais finos a que as operações da alma estão conectadas" (Ferguson, 2019, pp. $176-177)^{78}$.

Toda a argumentação sobre a influência do clima parece, no Ensaio, tentar explicar não os motivos que levam uma nação a progredir, já que esse é um princípio inerente à espécie, mas aqueles que mais propriamente obstam esse progresso. Ou seja, é preciso acomodar o princípio do progresso (necessário), em primeiro lugar, com o fato de que os estágios mais avançados do desenvolvimento da sociedade se limitam a uma porção específica do globo terrestre, e, em segundo, com a estagnação às quais certos povos estão sujeitos. Nesse quesito, o recurso à explicação através de causas físicas é

\footnotetext{
${ }^{75}$ Essa ponderação também é feita por Buffon, principalmente quando quer explicar os povos do Peru e do México, os quais, apesar da localização geográfica, são bastante desenvolvidos.

${ }^{76}$ Christopher Berry (2018/a) diz que, dentre "tais circunstâncias, Dunbar menciona 'a divisão de um país pelas montanhas, por lagos ou rios, a vizinhança ou distância do mar, situação insular ou continental, e a condição relativa das nações circunjacentes"” (p. 66).

${ }^{77}$ Como dissemos, Buffon já havia estabelecido que o homem é original da zona temperada e que este seria mesmo o "meio humano por excelência, aquele que oferece à espécie as melhores condições de vida e de desenvolvimento" (Duchet, 1995, p. 255).

${ }^{78}$ Esse é um contraponto de Ferguson à teoria de Montesquieu sobre a influência da temperatura sobre "as fibras exteriores do nosso corpo". Cf. Montesquieu, 2005, pp. 241-242.
} 
influência tanto de Buffon quanto de Montesquieu. Este, num capítulo de $O$ Espírito das Leis, cujo título é "causa da imutabilidade da religião, dos costumes, dos modos e das leis nos países do Oriente", diz que o clima quente dos países do sul (ao sul da Europa, como a China, por exemplo) confere a esses povos "uma fraqueza de órgãos", além de "certa preguiça de espírito naturalmente ligada à do corpo" que faz com que não sejam "capaz de nenhuma ação, de nenhum esforço, de nenhuma contenção"; portanto, isso explicaria por que "leis, os costumes e os modos, até mesmo daqueles que parecem indiferentes, como o modo de se vestir, sejam hoje no Oriente os mesmos de mil anos atrás" (Montesquieu, 2005, pp. 243-244). Em Ferguson, há um raciocínio muito próximo à Montesquieu: ele atribui ao "sol vertical" da região "uma suavidade capaz de amenizar os rigores do governo despótico" (Ferguson, 2019, p. 168) ${ }^{79}$ e conclui que "a moderna descrição da Índia repete a antiga, e o estado atual da China deriva de uma antiguidade remota sem paralelo na história humana" (Ferguson, 2019, p. 169). Argumento igualmente semelhante pode ser encontrado em Smith quando trata dos tártaros, cuja estagnação no estágio do pastoreio é consequência, segundo o autor, do clima da região: “[...] os tártaros sempre foram uma nação de pastores, o que sempre serão, dada a natureza de seu país, que é seca e muito acima da linha do mar, com poucos rios embora alguns muito grandes e cuja temperatura e ar são frios demais para a produção de qualquer grão [...]” (Smith, 1978, p. 220).

\section{II.vi. Teoria dos estágios: selvagem, bárbaro e polido ${ }^{80}$}

Como dissemos, a história natural da sociedade é elaborada através do sequenciamento dos degraus ou estágios de seu progresso, da mesma maneira como enumeramos os "degraus de transição de uma forma ou estado de existência a outro" em que se dá "os movimentos sucessivos" de qualquer indivíduo da natureza (Ferguson, 1792, vol. I, p. 191). Como a analogia sugere, a designação de estágios é um expediente

\footnotetext{
${ }^{79}$ Segundo J. G. Pocock (1999) esse tema pode ser denominado "o paradigma do despotismo oriental". Cf. Pocock, 1999, vol. II, pp. 356-357.

${ }^{80}$ Ferguson utiliza "polished", "commercial or polished nations" e "refinement". É preciso distinguir sociedades polidas de sociedades comerciais: algumas nações antigas alcançaram um alto grau de refinamento, ainda que não tivessem desenvolvido seu comércio. Quando fala das "maneiras das nações polidas e comerciais", nosso autor difere os romanos, povo "destinado a adquirir riqueza por meio da conquista e do espólio de províncias" e os cartagineses, cuja riqueza era resultado do "tráfico de mercadorias e dos dividendos de seus assentamentos comerciais" (Ferguson, 2019, p. 267).
} 
heurístico para organizar a diversidade de momentos no desenvolvimento seja da vida dos indivíduos, seja do progresso de uma nação.

Esses estágios sociais (estágio rude - selvagem e bárbaro - e sociedade civil polido ou comercial) que Ferguson utiliza para orientar a história da sociedade não passam de generalizações que exibem o encontro dos princípios da natureza humana com as "circunstâncias de sua situação externa" ${ }^{\text {: }}$ : são abstrações que permitem ao filósofo dar sentido à diversidade de circunstâncias às quais os homens estão submetidos. Partindo de uma natureza humana uniforme, "é importante identificar as regularidades" (Gautier, 2011, p. 11) circunstanciais presentes nas diversas expressões sociais da humanidade. $\mathrm{Na}$ verdade, Montesquieu foi quem primeiro sistematizou a complexa relação entre os diversos fatores aparentemente ocasionais das nações. Antes de tudo, ele estabeleceu uma relação entre a natureza do solo (fertilidade, declividade, isolamento etc.) com as diversas formas de governo: de modo geral, países férteis tendem à monarquia enquanto os inférteis tendem ao governo popular; e, ainda, os países "que a indústria dos homens tornou habitáveis e que precisam, para existir, desta mesma indústria requerem o governo moderado" (Montesquieu, 2005, p. 296). No entanto, o cultivo da terra não está relacionado à sua fertilidade, mas ao seu grau de liberdade: “[...] se dividirmos a terra com o pensamento ficaremos espantados de ver a maior parte do tempo desertos em suas partes mais férteis e grandes povos nas partes onde o solo parece tudo negar" (Montesquieu, 2005, p. 294); é que as invasões dos países férteis causam muita devastação e deslocamentos, tornando muitas dessas regiões inabitadas. O cultivo ou não da terra se relaciona também com o número populacional de cada povo, pois "assim como o produto do solo inculto está para o produto de um solo cultivado, o número dos selvagens, num país, está para o número de lavradores, em outro" (Montesquieu, 2005, p. 298). Caçadores e pastores precisam de grandes territórios para desenvolver suas atividades e por isso aparecem em menor número do que lavradores, por exemplo. $\mathrm{O}$ autor mostrou ainda como cada modo de subsistência (caça, pastoreio, agricultura e comércio) necessita de um código de leis mais ou menos extenso, a depender da modalidade econômica desenvolvida: um povo que vive da caça quase pode prescindir de um código de leis, ao passo que um povo que se dedica ao comércio precisa de um código mais extenso ${ }^{82}$.

\footnotetext{
${ }^{81}$ Segundo Dugald Stewart: "necessitamos suplantar o fato pela conjectura; e quando somos incapazes de verificar como os homens de fato conduziram a si mesmos em ocasiões particulares, precisamos considerar de que maneira é provável que tenham procedido, dos princípios de sua natureza e das circunstâncias de sua situação externa", citado por Berry, 2013, p. 33.

82 "As leis têm uma relação muito grande com o modo como os diversos povos obtêm a subsistência. É preciso um código de leis mais extenso para um povo que se dedica ao comércio e ao mar do que para um
} 
Ainda que Montesquieu tenha conseguido relacionar as particularidades físicas e morais (natureza do solo, forma de governo, código de leis mais ou menos extenso, número populacional e meio de subsistência) de cada povo a fim de dar inteligibilidade aos fenômenos sociais, não há em sua filosofia uma historicidade desses elementos, ou seja, não há uma história do progresso da sociedade em estágios, como encontramos em Ferguson. Isso não quer dizer que Montesquieu não estava ciente da maior complexidade das nações comerciais em relação aos bárbaros ou selvagens; o que não podemos encontrar nele é um sequenciamento cronológico, ao menos em teoria, que organiza as diversas nações não só temporal, mas também geograficamente.

Podemos encontrar um modelo de progresso social em estágios em Adam Smith, principalmente nas lições de Glasgow. Em sua teoria - conhecida como teoria dos quatro estágios $^{83}$ - os estágios são estabelecidos de acordo com os meios de subsistência ${ }^{84}$ identificados por Montesquieu (caça e pesca, pastoreio, agricultura e comércio), numa sequência que vai do mais simples, a caça e a pesca, ao mais complexo, o comércio. Esse sistema classificatório não apenas diz respeito à forma de vida material de cada agrupamento ou nação humana, mas tenta organizar todas as características comuns a cada estágio, como governo e sistema de leis, desenvolvimento das artes e ciências, maneiras etc.

Os caçadores são os selvagens sem qualquer forma de governo ou código de leis; eles ainda desconhecem a propriedade e admitem apenas a posse provisória do fruto de seu trabalho. A noção de propriedade, e com ela do governo, surge apenas com os pastores, cuja posse regular dos rebanhos traz certa ideia de estabilidade e fixidez.

Devo dizer que a era dos pastores é aquela em que o governo começa. A propriedade o torna absolutamente necessário. Na situação em que se tenha uma vez concordado que uma vaca ou ovelha deva pertencer a uma certa pessoa não apenas quando está de fato em sua posse mas também quando está dispersa, é absolutamente necessário que a mão do governo seja continuamente exibida e que a comunidade afirme seu poder para preservar a propriedade dos indivíduos" (Smith, 1978, p. 208).

\footnotetext{
povo que se contenta com cultivar suas terras. Precisa-se de um código maior para este último do que para um povo que vive de seus rebanhos. Precisa-se de um código mais para este último do que para um povo que vive da caça" (Montesquieu, 2005, p. 297).

${ }^{83}$ Cf. Meek, R. Smith, Marx and After: Ten Essays in the Development of Economic Thought. Chapman and Hall, 1977.

${ }^{84}$ Nas Instituições, Ferguson apresenta uma teoria de três estágios (caça e pesca correspondem a um mesmo estágio) a partir dos meios de subsistência: "As artes que os homens exercem para a subsistência são pesca, caça, pastoreio e agricultura" (Ferguson, Instituições, 2019, p. 398). Embora o comércio apareça na mesma seção, ele não é incluído nas artes de subsistência. Uma discussão aprofundada sobre o modelo de três estágios, em que se exclui o comércio como um modo primário, está em Berry, 2013, pp. 38-50.
} 
Porém, é apenas com o assentamento promovido pela agricultura - os pastores são, na maior parte do tempo, nômades - que uma forma regular de governo e um sistema de justiça surgirão. Com a segurança adquirida dessa forma, somada à fertilidade do solo de certas regiões, a indústria humana pode se desenvolver, permitindo aos homens o cultivo das artes e das ciências. Ao fim, circunstâncias favoráveis ao transporte de mercadorias farão surgir o comércio entre estados, o que trará ainda mais desenvolvimento para uma dada sociedade, gerando "opulência e abundância" (Smith, 1978, p. 334).

Embora Smith tenha preferido, ao menos em suas lições ${ }^{85}$, seguir a nomenclatura dos modos de subsistência para determinar esses estágios, isso não significa necessariamente que haja uma primazia na filosofia do autor do fator econômico no progresso das sociedades ${ }^{86}$ ou que as necessidades materiais sejam os únicos "fatores de transformação e de passagem" (Gautier, 2011, p. 11) de um estágio a outro. Na verdade, os meios de subsistência formam um padrão organizativo para se pensar historicamente o desenvolvimento de outras características das sociedades humanas: Smith aplica essa teoria para elaborar, por exemplo, a história do governo ou da filosofia ${ }^{87}$.

Assim, quando estabelece em termos gerais a necessidade como motor do progresso $^{88}$, Smith não se limita a tratar da necessidade material: ainda que inicialmente o aperfeiçoamento seja impulsionado pelas necessidades básicas de sobrevivência, como a alimentação e a moradia, com o desenvolvimento das sociedades, as carências humanas se tornam menos imediatas, surgem a conveniência e o supérfluo, e também mais complexas, a língua se torna mais abstrata e cria-se necessidades intelectuais e estéticas. No entanto, o aperfeiçoamento aparece primeiramente como uma necessidade por conta da natureza "desamparada e indigente" do homem:

\footnotetext{
${ }^{85}$ Cf. Lectures on Jurisprudence. Em A Riqueza das Nações, livro III, Smith marca o progresso das nações europeias utilizando as categorias "feudalismo" e "sociedade comercial".

${ }^{86}$ Como quer Ronald Meek (1977), por exemplo. Segundo David Winch (1978), "Os quatro estágios econômicos oferecem apenas uma vaga estrutura, e os modos de subsistência exercem uma influência no padrão de eventos, se muito, apenas quando ligados a outros fatores, os quais incluem condições geográficas favoráveis, acidentes históricos, e mesmo as personalidades dos monarcas" (p. 63).

${ }^{87}$ Uma história das leis e do governo é apresentada em Lectures on Jurisprudence; uma história do conhecimento humano é apresentada em The History of Astronomy. Ademais, segundo Berry (2018/b), Smith pretendia completar dois manuscritos: "O primeiro ele identificou como 'um tipo de História Filosófica de todos os diferentes ramos da Literatura, da Filosofia, Poesia e Eloquência', o outro, 'um tipo de teoria e História da Lei e do Governo' (Corr 287)" (p. 5).

${ }^{88} \mathrm{Em}$ Considerações a respeito da primeira formação das línguas, Smith atribui o surgimento das línguas à necessidade de tornar as carências inteligíveis: "Dois selvagens, que nunca aprenderam a falar, mas que foram criados distantes das sociedades dos homens, começariam naturalmente a formar esta língua através da qual se esforçariam para tornar suas carências mútuas inteligíveis entre si [...]" (Smith, 1811, vol. V, p. $3)$.
} 
O homem recebeu como recompensa da natureza razão e engenho, arte, inventividade e capacidade de aperfeiçoamento muito superior àquela dada a qualquer outro animal; porém, está, ao mesmo tempo, numa condição muito mais desamparada e indigente com relação ao sustento e conforto de sua vida. Todos os outros animais encontram seu alimento no estado que desejam [...]. Mas o homem, de uma estrutura mais delicada e uma constituição mais débil, não encontra nada tão adaptado a seu uso que não necessite de aperfeiçoamento e preparação para ajustá-lo a seu uso (Smith, 1978, p. 334).

Portanto, o homem é compelido por sua situação natural a aperfeiçoar tudo que lhe é necessário à sobrevivência, até mesmo a comida, que crua não parece "ser mais agradável ou benéfica a ele", ainda que algumas "nações selvagens" provem que o "estômago humano possa digerir a comida em seu estado natural e sem preparação" (Smith, 1978, p. 334). Da mesma forma, a vestimenta e a moradia são necessidades que servem inicialmente para protegê-lo da temperatura do ar, sem as quais ele dificilmente poderia sobreviver. Porém, “o mesmo temperamento e inclinações que o impeliu a fazer esses aperfeiçoamentos, impulsiona-o a ainda maiores refinamentos":

Esse modo de vida parece rude e desmazelado e não mais pode satisfazê-lo; ele busca sutilezas elegantes e refinamento. O homem, diferentemente de todos os animais do globo, é o único que considera as diferenças das coisas que de forma alguma afeta sua real substância ou que dê a ele qualquer vantagem superior em prover as carências da natureza (Smith, 1978, p. 335).

As "carências da natureza" que o impulsionam primeiro no simples aperfeiçoamento de artigos de sobrevivência, através da prática das artes mecânicas ${ }^{89}$, gradualmente se transformam em necessidades mais sutis e abstratas: o homem não necessita apenas de uma roupa para aquecê-lo no inverno, mas deseja também um bom tecido, um corte perfeito e uma composição harmônica de cores. No entanto, ainda que haja uma maior urgência das necessidades básicas ligadas à subsistência, e com isso uma prioridade na prática daquelas artes destinadas a supri-las, Smith afirma que a música e a dança, artes imitativas mais naturais, estão presentes mesmo entre as nações mais bárbaras e "nenhuma nação foi revelada tão incivilizada a ponto de não as possuir absolutamente" (Smith, 1811, vol. V, 265). Mas é apenas com a produção de "opulência e abundância" é que pode haver realmente o desenvolvimento das artes de forma geral,

\footnotetext{
${ }^{89}$ Smith parece fazer uma separação entre artes elegantes (dentre elas estão as artes imitativas) e artes mecânicas. Uma separação entre artes mecânicas e artes liberais (ou belas artes) pode ser encontrada em Bacon e no verbete homônimo da Enciclopédia.
} 
que por sua vez engendram necessidades mais refinadas. Para Smith, os "avanços consideráveis nas muitas artes e ciências e manufaturas" dependem de formas mais complexas de subsistência, de governo e de leis; enfim, de uma forma mais civilizada de sociedade.

Podemos facilmente conceber que um povo desse tipo [povos que se estabeleceram em cidades e se tornaram repúblicas], que fixou moradia em um país onde vivesse em grande tranquilidade e segurança e em um solo capaz de lhe prover bons retornos do cultivo, não apenas aperfeiçoaria a terra, mas também faria avanços consideráveis nas muitas artes e ciências e manufaturas, desde que tivesse a oportunidade de exportar os suntuosos produtos e frutos de seu trabalho. Essas duas circunstâncias são absolutamente necessárias para ocasionar esse aperfeiçoamento nas artes da vida entre um povo nesse estado (Smith, 1978, p. 223, grifo nosso).

Dessa forma, a possibilidade de exportar os frutos do trabalho - principalmente os produtos do cultivo da terra -, ou seja, o comércio entre os estados, além da "tranquilidade e segurança" resultantes de um governo regularmente estabelecido, é "absolutamente" necessário para o aperfeiçoamento das artes.

Como Smith, Ferguson concebe o homem como nascido em uma situação de existência precária, "o homem nasce nu, indefeso e exposto a dificuldades muito maiores do que qualquer outro animal" (Ferguson, 1792, vol. I, p. 239), e sendo assim, é estimulado a superar essas inconveniências por um princípio de progresso que nosso autor denomina ambição ${ }^{90}$. Essa é uma paixão que impulsiona o homem não somente a superar suas carências mais imediatas, quando opera "nas preocupações da mera vida animal", mas age indefinidamente e não "é satisfeita com nenhuma medida específica de gratificação: ela continua a impulsionar sua busca mesmo depois que as mais altas realizações são obtidas [...]". Ademais, esse princípio de perfeição opera "no progresso da sociedade e na escolha de suas instituições" (Ferguson, 1792, vol. I, p. 235), ou seja, é o próprio motor do progresso social.

A ação da ambição na superação das necessidades (não apenas das carências básicas) é o que justifica "as artes da vida humana, sejam comerciais ou políticas" (Ferguson, 1792, vol. I, p. 239), mas também as artes literárias e liberais ${ }^{91}$. Segundo nosso

\footnotetext{
${ }^{90}$ Sobre isso, conferir nota 23.

91 Para Christopher Berry (2018/a), Ferguson faz uma tripartição das artes em comercial, política e intelectual (ou belas artes). Nas Instituições, Ferguson diz que "as atividades externas dos homens se limitam à procura de meios de segurança, subsistência, moradia e ornamento. Eles praticam uma variedade de artes, ou invenções, para estes propósitos; e são mais ou menos bem-sucedidos à proporção que eles multiplicaram, dividiram e completaram as artes" (Ferguson, Instituições, 2019, pp. 397-398). Já nos
} 
autor, essas artes são praticadas simultaneamente ${ }^{92}$ e "sem qualquer suposta ordem de aparecimento por causa de seus graus comparativos de importância ou da urgência de ocasiões nas quais são praticadas" (Ferguson, 1792, vol. I, p. 240). Ferguson afirma explicitamente que não há uma precedência de uma ou outra arte na vida humana ${ }^{93}$, como se elas pudessem ser hierarquizadas com base na maior urgência de certas carências; como a obtenção da comida, aperfeiçoada pelas artes mecânicas, parece ter precedência na filosofia de Smith.

Dessa forma, as artes estão igualmente presentes em todos os estágios, não sendo apenas fruto de certas condições dos estágios mais avançados: todos os povos, dos mais rudes aos mais civilizados, praticam uma variedade de artes de acordo com suas necessidades. No entanto, isso não quer dizer que não haja um enorme progresso nas artes nas sociedades polidas, mas que a "arte é natural ao homem" e "a habilidade que ele adquire após sucessivas épocas de prática é apenas o aperfeiçoamento de um talento que ele possui desde sempre" (Ferguson, 2019, p. 239).

Vitrúvio encontra os rudimentos da arquitetura em uma tenda cita. O armeiro encontrará os primeiros produtos de sua vocação na funda e no arco, e o carpinteiro, os da sua, na canoa do selvagem. Mesmo o historiador e o poeta encontrarão os primeiros esboços de suas artes na fábula e na canção, que celebram as guerras, os amores e as aventuras dos homens em sua condição mais rude (Ferguson, 2019, p. 239).

É que, na verdade, a ornamentação e a decoração estão igualmente presentes, para Ferguson, em todos os estágios. Ele diz nas Instituições que "os homens, em todas as eras, gostam de decoração; eles combinam o ornamento com os meios de subsistência e moradia" (Ferguson, Instituições, 2019, p. 399). Isso quer dizer que o cocar decorado de um selvagem americano é tão supérfluo e ao mesmo tempo necessário quanto a peruca usada por um membro do parlamento britânico.

Princípios, nosso autor menciona as artes comerciais e políticas (Ferguson, 1792, vol. I, p. 239). No Ensaio, ora ele faz uma bipartição entre artes mecânicas e comerciais e artes literárias e liberais (Ferguson, 2019, p. 243), ora menciona as artes civis e as artes comerciais.

92 A simultaneidade das artes faz com que Berry (2018/a), no ensaio 'But Art itself is Natural to Man': Adam Ferguson and the Principle of Simultaneity, questione a própria existência de uma teoria de estágios em Ferguson.

${ }^{93}$ Essa noção de simultaneidade das artes é comum a toda obra do autor, inclusive o Ensaio; há apenas uma passagem, neste último, que contradiz a ideia geral do autor: "Após uma pequena observação sobre o que se passa na vida humana, devíamos estar aptos a concluir que o cuidado com a subsistência é a principal origem das ações humanas. Essa consideração leva à invenção e prática das artes mecânicas; serve para distinguir a diversão dos negócios; e, dentre muitas, dificilmente admite competição com qualquer outro objeto de ocupação ou atenção" (Ferguson, 2009, p. 35). 
O conveniente e o ornamental em suas várias formas, ainda que rudes, são considerados no mesmo período que o necessário; e a mesma pessoa, que subsiste de refeição em refeição através dos precários retornos da caça, não é, nos intervalos de sua necessidade, menos aplicada ao ornamento de si mesma, de sua vestimenta e da construção de sua habitação, de suas armas, do que o é no zelo com que procura sua comida. Considera-se a excelência do pensamento engenhoso e da emoção ardente na canção que se recita ou na conversação conduzida na assembleia da tribo. Concebe-se uma honra a ser alcançada e uma dignidade de caráter a ser preservada, em que a ambição não pode ser sobrepujada, mesmo por aqueles que estão mais desobrigados efetivamente das distrações associadas aos cuidados e necessidades inferiores da vida animal (Ferguson, 1792, vol. I, p. 240).

A disposição para a ornamentação é concomitante à disposição para moralidade, esta que em Ferguson é um traço exclusivamente humano e está presente em toda a sua história, ou seja, é coeva à espécie. Como vimos no capítulo anterior, a lei de apreciação, que responde pela nossa capacidade de aprovação moral, não é mais do que um princípio de perfeição, que impulsiona os homens a todo tipo de aperfeiçoamento: social, moral e político, mas também estético.

\section{II.vii. As nações rudes}

Quando perscrutamos o material historiográfico, inferimos que a história humana teve um começo, quer dizer, que ela é limitada a um período de tempo. Assim, podemos estabelecer esse início, mesmo para as nações mais avançadas, a partir de uma origem insignificante e então descrever o "progresso lento e gradativo, ao cabo do qual viriam a se destacar" (Ferguson, 2019, p. 119). Em sua história da sociedade, Ferguson inicia a descrição com as nações rudes, que podem ser denominadas selvagens ou bárbaras. Montesquieu, em $O$ Espírito das Leis, já havia apontado para uma diferença entre os povos selvagens e bárbaros; segundo ele, "existe a seguinte diferença entre os povos selvagens e os povos bárbaros: os primeiros são pequenas nações dispersas que, por algumas razões particulares, não se podem reunir. Normalmente, os primeiros são povos caçadores; os segundos, povos pastores" (Montesquieu, 2005, p. 299) ${ }^{94}$. Para Ferguson, ainda que haja essa diferença, é difícil, na prática, delimitar precisamente em

\footnotetext{
${ }^{94}$ Rousseau também faz uma separação entre selvagens e bárbaros; para o genebrino, essa diferença é ainda maior pelo fato de os povos selvagens estarem ainda num estado de natureza, enquanto os bárbaros já estão em sociedade e conhecem a propriedade.
} 
qual momento uma nação se encontra: é que não há, factualmente, uma fixidez tão grande dos estágios, eles são apenas modelos teóricos para sistematizar o modo como uma nação progride ao longo do tempo.

De forma geral, as nações podem ser classificadas de acordo com a ausência ou presença de impressões de propriedade e de interesse, sendo os selvagens os únicos povos sem essas impressões. No que concerne aos meios de subsistência, de forma um pouco diferente de Montesquieu, os selvagens vivem da caça e os bárbaros do pastoreio e da agricultura. Podemos especificar três características principais que separam os selvagens dos demais povos: ausência de propriedade, de interesse e de subordinação e governo. $O$ bárbaro, por outro lado, já está familiarizado com a propriedade, embora ainda não haja leis para regulá-la, e com as relações de patrono e cliente, servo e senhor, ou seja, ele já conhece a subordinação e é classificado de acordo com medidas de riqueza.

As principais características do estágio selvagem é a igualdade, a liberdade e a justiça entre os membros de uma comunidade; nas palavras de Ferguson: "eles [os selvagens] não admitem distinções hierárquicas ou de condição" e "não têm outro grau de subordinação a não ser a distribuição de funções segundo diferenças de idade, talento e disposição. Qualidades pessoais propiciam a ascendência de um indivíduo em ocasiões em que são requeridas; mas, em tempos de relaxamento, não deixam vestígio de prerrogativa ou poder" (Ferguson, 2019, p. 132). A justiça aqui é entendida de forma muito diferente da justiça das nações comerciais (uma vez que o interesse ainda não existe): os selvagens agem por meio de afetos e apetites, não por leis, como veremos mais adiante.

Como o progresso é lento e gradual, no estágio bárbaro, os homens ainda mantêm características selvagens: "continuam avessos ao trabalho, com gosto pela guerra, admirando a fortaleza e, no dizer de Tácito, mais pródigos de sangue do que de suor" (Ferguson, 2019, pp. 150-151). Por esse motivo e porque os laços sociais se tornaram menos firmes, provavelmente as desordens domésticas ficaram mais frequentes. A explosão de conflitos é importante para a narrativa de Ferguson porque é um ensejo, por um lado, para que os guerreiros se destaquem, tanto por sua posição quanto por seu privilégio na posse do espólio; por outro, para que novos laços sociais sejam feitos; nas palavras de Ferguson: "O que ameaçava arruinar e desorganizar cada uma das boas disposições que se encontram no coração humano, o que parecia banir a justiça das sociedades dos homens, tende, na realidade, a unir a espécie em clãs e fraternidades, ameaçadoras, de fato, e hostis entre si, mas, no interior de cada uma, fiéis, desinteressadas e generosas" (Ferguson, 2019, p. 155). Assim, nessa descrição são apontadas as 
mudanças sociais que decorrem no interior de uma nação, fazendo com que surjam novas paixões - principalmente o interesse -, e distinções - desigualdade e subordinação -, culminando no aparecimento da propriedade e do governo. Embora esse seja ainda desconhecido na sua forma regular nas sociedades rudes, Ferguson aproxima a organização dos selvagens a uma democracia e a dos bárbaros, a uma monarquia (mesmo que a disparidade de posição não seja suficiente para possibilitar a forma monárquica propriamente).

Embora os selvagens não distingam a propriedade, ela "é uma questão de progresso" (Ferguson, 2019, p. 129), e o desejo de obtê-la é dado pela experiência. Porém, o que ocorrerá no interior dessas nações felizes, como o próprio autor coloca, para fazer com que elas saiam do estágio selvagem e avancem ao bárbaro? Essa é talvez a passagem mais difícil de representar teoricamente, e ela coincide com a saída do estado de natureza de alguns autores, como Hobbes e Rousseau.

Factualmente, as principais razões para a passagem do estado selvagem para o bárbaro são: quando os pais desejam obter melhores provisões para seus filhos e quando indivíduos não encontram mais em seus parceiros a mesma inclinação no empenho com relação às coisas públicas (Ferguson, 2019, p. 149). Nessas situações, os homens, movidos por emulação, inveja e um sentido de necessidade, passam a se preocupar com sua fortuna pessoal e a entreter sentimentos de interesse. De acordo com o modelo teórico, o surgimento do interesse e o afrouxamento da união da sociedade (bands of society) ${ }^{95}$ são os aspectos característicos do surgimento da propriedade, na medida em que possibilitam que os homens trabalhem separadamente e desejem a posse exclusiva dos frutos do seu trabalho ${ }^{96}$.

De fato, a transição do estado selvagem para o bárbaro foi apresentada de forma mais descritiva do que explicativa, dando ensejo para críticas como a de Ronald Hamowy

\footnotetext{
${ }^{95}$ Nesse momento da história da espécie, dentre as três propensões ou leis da vontade que caracterizam a natureza humana (disposição para a sociedade, para a autopreservação e para a excelência), há um esmorecimento da disposição para a sociedade e a predominância da disposição para a autopreservação. $O$ interesse aqui não pode ser comparado ao egoísmo, ele é apenas a preocupação "por coisas consideradas úteis ou necessárias aos propósitos da vida animal" (Ferguson, Instituições, 2019, p. 441), uma paixão que "está compreendida na lei de autopreservação" e é uma aplicação parcial desta lei, fundada na opinião da grande importância das coisas externas" (Ferguson, Instituições, 2019, p. 442). As riquezas, conforme a sociedade progride, passam a conferir também posição social (combinação entre a propensão à excelência ou lei da apreciação e a propensão ou lei de autopreservação).

${ }^{96}$ Ferguson diferencia a posse - que é uma condição de detenção temporária, circunstancial e muitas vezes compartilhada -, da propriedade - posse exclusiva e reconhecida por um grupo. Os selvagens têm, como propriedade, apenas alguns poucos itens necessários à sua preservação, como "as armas, os utensílios e as peles que o indivíduo carrega consigo"; o fruto de seu trabalho, "por ser aquisição dos muitos que pescam ou caçam em conjunto, pertence à comunidade, sendo ou imediatamente utilizado ou acrescido aos estoques públicos" (Ferguson, 2019, p. 129). Como em Montesquieu, a propriedade só será realmente assegurada com a divisão de terras e com o surgimento das leis civis entre os povos que se dedicam à agricultura. Cf. Montesquieu. O espírito das leis. São Paulo: Martins Fontes, 2005, p. 299.
} 
(2005), para quem "as causas dessa transição da selvageria para o barbarismo são obscuras" (p. 12) e as de Vincenzo Merolle e Eugene Heath (2009), os quais, de modo muito peremptório, sentenciam que "embora Ferguson seja com frequência associado à teoria dos estágios, sua articulação da mudança e diversidade social não inclui nenhuma consideração exata de estágios específicos do desenvolvimento social ou qualquer especificação do modo de transição de um estágio a outro" (p. 8). Claude Gautier (2011), por sua vez, vê na "emergência e predominância progressivas da figura do interesse individualizado" que resultou do enfraquecimento dos laços sociais, "um dos fatores de transformação e de passagem" de um estágio a outro (p. 11) ${ }^{97}$.

A bem da verdade é que parece não haver, para Ferguson, necessidade de explicar a passagem de um estágio a outro para além de demonstrar a analogia entre o progresso do indivíduo e o progresso da sociedade (da espécie): da mesma forma que o indivíduo avança da infância à adolescência e à idade adulta, as nações progridem de sua infância social, o estágio rude (selvagem e bárbaro), até seu amadurecimento, o estágio polido. Ambos os indivíduos e as sociedades estão sujeitos a diversas vicissitudes que podem, por um lado, favorecer esse desenvolvimento, ou, por outro, impedi-lo.

Como vimos, Ferguson se detém mais a explicar as causas que impendem o progresso das nações, do que o próprio progresso, que é um princípio natural (um princípio de progressão ou ambição). A introdução da questão do clima antecedendo a descrição das nações polidas demonstra que também na passagem do estágio bárbaro para o polido há uma inflexão, não com o surgimento de novas paixões e distinções, como na transição entre o estágio selvagem e bárbaro, mas com uma restrição factual (em teoria, todas as nações estão submetidas ao princípio de progressão) dada pelo fator climático e situacional. A dimensão geográfica da investigação, que, no estágio rude, compreendia todo o globo terrestre, restringe-se, na descrição da sociedade civil propriamente, às zonas temperadas.

Se quisermos acompanhar a história da sociedade civil, nossa atenção deve se voltar principalmente para tais exemplos [de climas felizes]; devemos dar adeus às regiões da Terra nas quais, devido aos efeitos de sua localização e de seu clima, nossa espécie parece ser obstada em suas ocupações nacionais ou inferior quanto aos poderes da mente (Ferguson, 2019, p. 180).

\footnotetext{
${ }^{97}$ Apesar de haver um exagero de Gautier ao atribuir tal motivação ao interesse, sua leitura de Ferguson como crítico do individualismo, na qual o Ensaio expressa uma maior preocupação com a figura do homo politicus do que com a do homo oeconomicus, contribuiu para reposicionar a obra do autor na controversa história do pensamento liberal. Cf. Gautier, C. Adam Ferguson, An Essay on the History of Civil Society: nature, histoire et civilisation. Paris: PUF, 2011.
} 


\section{II.viii. A sociedade civil}

A história do estágio polido, da sociedade civil propriamente dita, no Ensaio, é tratada como história da política (policy) e da arte. Ferguson descreve a passagem do estágio bárbaro para o polido mostrando como houve um processo de consolidação de princípios já presentes, embora de forma incipiente, no estágio anterior.

[...] os assuntos humanos continuam a progredir. O que numa geração era propensão a seguir a espécie se torna, nas épocas subsequentes, princípio de união natural. O que na origem era uma aliança para a defesa comum se transforma em um plano deliberado de força política e os cuidados com a subsistência, em anseio pelo acúmulo de riquezas e em fundamento das artes comerciais (Ferguson, 2019, p. 181).

O modo como esse processo de transição se dá exatamente depende de muitas circunstâncias ocasionais; no entanto, é possível estabelecer regras gerais. Em primeiro lugar, as discórdias domésticas surgidas ainda no estágio rude, causadas pelo desejo pela propriedade individual e o esmorecimento dos laços sociais, frutos de paixões como interesse, ambição e avareza, vão aumentando até as pequenas comunidades estabelecerem instituições políticas para a manutenção da ordem interna e a defesa externa. A depender de acidentes, como o temperamento (character) de um povo e eventos de guerra, mas principalmente do número de indivíduos e a extensão do território, essas pequenas comunidades (que Ferguson chama de principados, como o exemplo grego) darão origem a diferentes formas de organização política: 1) pequenas sociedades em contenda entre si tenderão a se reunir em torno de um único líder (o que pode vir a ser posteriormente uma monarquia, ou sua forma corrompida, o despotismo); 2) quando os indivíduos se tornam refratários, quando partidos ou o corpo coletivo escolhem agir por si próprios, eles tenderão a formar repúblicas (ou sua forma corrompida, a anarquia) e 3) quando mudanças de condições e maneiras dão origem a uma nobreza ou a superstição cria uma ordem de homens, teremos mais possivelmente uma aristocracia (a forma corrompida da aristocracia é o abuso de poder das famílias nobres ou dos sacerdotes). A história da humanidade mostra também exemplos de formas mistas de governo, como é o caso da Inglaterra, e de exceções à tipologia, como a Suécia, cujo território é extenso, embora sua organização política seja na forma de uma república.

Ainda que Ferguson detalhe o processo de formação dos governos (em clara referência à Montesquieu), essa tipologia tem, no Ensaio, um alcance restrito, mesmo porque um governo regular está presente apenas no estágio polido. Com efeito, o que 
importa para o autor, na história da sociedade, é mostrar as semelhanças que caracterizam as nações em cada estágio de seu desenvolvimento, sendo a forma de governo apenas uma delas. A discussão política de Ferguson não se restringe, desse modo, às formas de governo, e a noção de sociedade civil é expressão dessa gama de circunstâncias comuns às nações no seu período mais avançado.

Reinhart Koselleck (2002) mostra como o termo societas civilis foi a tradução que Cícero deu ao termo koinonia politike de Aristóteles, cujo sentido, politicamente determinado, era de "uma comunidade de cidadãos autogovernada" (p. 213). Ainda que haja uma enorme diferença entre a realidade da polis grega e da civitas romana, tanto para Aristóteles como para Cícero, a sociedade civil não diferia da "sociedade política" (Smith, 2019, p. 150) ou do "Estado" (Berry, 2018/a, p. 125). Na modernidade, com Hegel, a sociedade civil (Bürgerliche Gesellschaft) seria uma terceira esfera entre a família e o Estado; segundo Craig Smith (2019), o termo "abrange a interação econômica da comunidade e os arranjos institucionais necessários para a obtenção da subsistência” (p. 151). Assim, o autor alemão abre espaço para nossa concepção contemporânea de sociedade civil, inteiramente destacada da determinação política e mais associada às formas institucionais relacionadas aos indivíduos de uma dada comunidade organizados voluntariamente.

No Iluminismo Escocês, o termo sociedade civil (civil society) não se afastou completamente de sua determinação política; para Christopher Berry (2018/a), a sociedade civil nesse período estaria no meio do caminho entre a concepção antiga (de Aristóteles e Cícero) e a concepção moderna de Hegel: haveria um "espaço conceitual" para a possibilidade de se pensar a sociedade civil como expressão da "interligação de instituições que incluem a religiosa, juntamente com a econômica, a familiar, de hábitos, costumes e a política" (p. 137), ou seja, a sociedade civil não se esgotaria numa noção de Estado, mas também não seria ampla o suficiente para acompanhar a tripartição de Hegel (p. 125). Porém, ainda segundo Christopher Berry (2018/a), não haveria sociedade civil, “a menos que exista um 'Estado' forte, que não seja local (nacional) e que seja limitado por regras [...]" (p. 134), pois é justamente a "estrutura de lei comum e estabelecida" que "propriamente permitiu coexistir uma variedade de instituições e sistema de valores" (p. 138) nessas sociedades civis. Assim em Ferguson, a questão central da sociedade civil remonta à noção política, sob a ótica do estado de direito (rule of law). 
Com efeito, civilizar para Ferguson significa organizar a partir de convenções ${ }^{98}$, na forma regular da lei e da política (policy). Os selvagens se relacionam entre si por meio de afeto ou rivalidade, não conhecem a desigualdade nem a subordinação e o mínimo de hierarquia que admitem é resultado de diferenças naturais. Por outro lado, o surgimento da propriedade, com o pastoreio e a agricultura, impõe acordos expressos (em forma de lei $\left.{ }^{99}\right)$ e gera subordinação, criando lideranças e posteriormente o governo. Há, portanto, duas formas de mediar as relações entre os indivíduos: "devem ou ao respeito e ao afeto que têm uns pelos outros ou a restrições impostas por lei" (Ferguson, 2019, p. 224). A história da sociedade civil descreve o processo gradual e ascendente da convenção ${ }^{100}$ na mediação das relações humanas: inicialmente, temos uma justiça baseada nos afetos, com os selvagens; os bárbaros introduzem uma mediação do costume e da hierarquia e a sociedade civil coloca em prática um sistema formal de regras de justiça, juntamente com um aparato administrativo para torná-lo efetivo. Assim, a sociedade civil seria ao mesmo tempo o acúmulo histórico que resulta do processo de civilização e o estágio polido propriamente. Ferguson usa às vezes o adjetivo "civilizado" (civilized) como sinônimo de "polido" (polished). No Ensaio, lemos que o termo polido, em "acepções mais recentes se referem [...] à proficiência das nações nas artes liberais e mecânicas, na literatura e no comércio, e civilizados são os homens eruditos, da moda e comerciantes", ou seja, em sua época, nações polidas ou civilizadas são aquelas que não apenas adotaram um complexo sistema legal e político, mas igualmente aperfeiçoaram as artes e as ciências e o comércio. No entanto, Ferguson acrescenta que "a julgar pela etimologia, o termo polido referia-se originalmente ao estado das nações quanto a suas leis e governo, e homens civilizados eram os que punham em prática os deveres do cidadão" (Ferguson, 2019, p. 286). Há, no uso que Ferguson faz do termo, uma tensão entre os dois sentidos, o sentido original e o sentido moderno; isso ficará mais explícito na discussão sobre o conceito de civilização.

\footnotetext{
${ }^{98}$ No Ensaio, Ferguson fala em uma "convenção formal", que seria implementada pela sociedade civil, mas sem a qual a humanidade poderia sim subsistir: "Sem a rivalidade entre as nações e a prática da guerra, a sociedade civil dificilmente teria encontrado um objeto ou recebido uma forma. Os homens poderiam comerciar sem uma convenção formal, mas não teriam segurança sem um concerto nacional [...]" (Ferguson, 2019, p. 56)

99 "Lei é o tratado com o qual membros de uma mesma sociedade concordaram, sob o qual o magistrado e o súdito gozam de seus direitos e mantém a paz da sociedade. O desejo de lucro é um grande motivo para ofensas: a lei, portanto, refere-se principalmente à propriedade" (Ferguson, 2019, p. 224).

${ }^{100}$ A convenção não pode ser confundida com o artifício; aquela diz respeito a um conjunto de regras expressa e previamente acordadas, enquanto este é a própria natureza humana no seu processo de aperfeiçoamento. Segundo Ferguson, o homem "é, em certa medida, o artífice de sua própria estrutura" (Ferguson, 2019, p. 34). E também convencional não pode ser oposto a natural: não há em Ferguson, como em Rousseau, uma sociedade natural e uma sociedade civil; ambas são artificiais (isto é, naturais). O que temos é uma sociedade mediada por afetos ou por leis.
} 
Em um primeiro momento, ainda que sociedade civil e civilização ${ }^{101}$ sejam termos distintos, estão supostamente ligados, já que a consolidação das instituições políticas e legais (o processo de civilização) tem como efeito os avanços nas outras esferas institucionais que caracterizam a sociedade civil. No Ensaio, por vezes, a civilização aparece em oposição à rudeza ${ }^{102}$, ou seja, civilização e rudeza seriam os dois extremos do progresso da espécie, da mesma forma como estágio rude e estágio polido são os limites da história da sociedade: "esse progresso vai muito além de outros animais, não apenas no indivíduo, que progride da infância à idade adulta, mas também na espécie, que vai da rudeza à civilização" (Ferguson, 2019, p. 27) e "não é preciso traçar um paralelo entre as maneiras de nações inteiras, nos extremos de civilização e rudeza, para ver que os vícios dos homens não são proporcionais a suas fortunas ou que os hábitos de avareza e sensualidade não estão fundados em certos graus de riqueza ou em determinadas espécies de divertimento" (Ferguson, 2019, p. 341).

Esse viés de civilização, mais propriamente do adjetivo "civilizado" 103 , é muito semelhante ao que Hume concebe quando trata das monarquias civilizadas, caso da França, por exemplo:

\begin{abstract}
Mas se todas as espécies de governo se aprimoraram nos tempos modernos, o governo monárquico é o que parece ter feito os maiores avanços rumo à perfeição. Pode-se afirmar agora das monarquias civilizadas o que antes só se dizia em louvor das repúblicas: são um governo de leis, não de homens. Elas se mostraram passíveis de um grau surpreendente de ordem, método e constância. Ali, a propriedade está assegurada, a indústria é encorajada, as artes florescem e o príncipe vive seguro entre seus súditos, como um pai entre filhos (Hume, 2011, p. 67, grifos do autor).
\end{abstract}

Ou seja, dizer que uma nação é civilizada significa, primeiramente, dizer que seu governo está amparado nas leis: seu poder é expresso pelas leis, não pela arbitrariedade do príncipe. Para Hume, de fato, as leis são a salvaguarda contra a "opressão e a escravidão", características típicas das "monarquias bárbaras" (Hume, 2011, p. 88), e condição tanto para a estabilidade e a ordem de um governo quanto para "grandes refinamentos e aprimoramentos da razão humana" (Hume, 2011, p. 89). Hume opõe,

\footnotetext{
${ }^{101}$ Sobre a história do termo civilização, vide Michel Malherbe (2005) e Pedro Paulo Pimenta (2013).

${ }^{102}$ Michel Malherbe (2005), em referência à concepção de civilização em Hume e em Ferguson diz que "a civilização estando em oposição à barbárie e à rudeness" não pode ser considerada "uma entidade subsistindo independentemente", pois essa "noção é essencialmente relativa" (p. 169).

${ }^{103}$ A palavra "civilização" não aparece em Hume. Há, no entanto, o uso do termo "civilidade". Cf. Malherbe (2005), principalmente pp. 164-169.
} 
dessa forma, civilizado a bárbaro; um exemplo claro dessa diferença se dá nas situações de guerra: as nações civilizadas têm leis inclusive de guerra, enquanto as bárbaras, nem mesmo essas (Hume, 1975, p. 188). Em oposição à rusticidade, Hume usa o termo civilidade, que diz respeito às boas maneiras e à polidez no convívio social: "entre as artes do convívio social não há nenhuma mais prazerosa que a mútua deferência ou civilidade” (Hume, 2011, p. 96). Ademais, Hume vincula diretamente o fato de as monarquias terem se civilizado na modernidade ao encorajamento da indústria e o florescimento das artes; para o autor, civilização, civilidade e comércio estão relacionados: seu sentido de "civilizado" é o sentido propriamente moderno do termo.

Ainda que Ferguson atribua, como Hume, a segurança e a ordem às leis, e derive delas o florescimento das artes e das ciências, há diferenças inconciliáveis na posição dos dois filósofos. Por um lado, Hume afirma que:

[...] embora a lei, fonte de toda segurança e felicidade, demore a surgir em qualquer país e seja o lento produto de ordem e liberdade, a dificuldade de preservá-la não é a mesma que a de produzi-la. Ao contrário, quando deita raízes, ela é uma planta resistente, que quase nunca perece, apesar do mau cultivo dos homens e do rigor das estações (Hume, 2011, p. 94).

Para Ferguson, por outro lado, mesmo que um sistema de leis seja o resultado de grande engenho dos homens e tenha sido elevado à máxima perfeição jamais vista na história, no caso da Inglaterra, ele não é garantia da liberdade, pois "não é apenas nas leis que devemos buscar pela segurança da justiça, mas também nos poderes pelos quais ela foi obtida" (Ferguson, 2019, p. 237) pois "as leis mais equânimes no papel são consistentes com o mais exacerbado despotismo em sua administração”. Quer dizer, ao contrário da alegação de Hume sobre a resistência das leis, Ferguson reitera sua fragilidade: “[...] sem o vigor para sustentar o que é reconhecido como um direito, o mero registro ou a intenção débil não têm nenhuma valia" (Ferguson, 2019, p. 238).

O fato é que para nosso autor, a civilização não se esgota apenas no estabelecimento de um sistema de leis. O grau de civilização das sociedades depende igualmente de um dispositivo capaz, não somente de torná-las efetivas, mas mesmo de assegurá-las. Aqui, Ferguson parece restabelecer a etimologia de civil, que remete ao termo latino "civilis": a civilização, nesse sentido, diria respeito mais propriamente à condição de cidadania dos membros de uma sociedade, ou seja, ao fato de uma sociedade ter seus cidadãos politicamente ativos. A civilização estaria, então, mais relacionada a um dispositivo político alcançado pelas nações polidas, do que propriamente a um dispositivo 
econômico. Nos Princípios, Ferguson deixa claro que a civilização não se confunde com "o sucesso das artes comerciais":

O sucesso das artes comerciais, divididas em partes, requer uma certa ordem a ser preservada por aqueles que as praticam e implica uma certa segurança da pessoa e da propriedade, para a qual damos o nome de civilização; entretanto essa distinção, tanto na própria natureza da coisa quanto na derivação da palavra, pertence mais aos efeitos da lei e do estabelecimento político, nas formas da sociedade, do que a qualquer estado de mera posse lucrativa e riqueza (Ferguson, 1792, vol. I, p. 252).

A civilização, portanto, não tem relação necessária com o comércio; na verdade, o "sucesso das artes comerciais" pode se dar em decorrência dela, como seu efeito, não como sua causa e também não de modo inevitável (Ferguson, 1792, vol. I, p. 252).

A civilização foi conspícua em nações que fizeram pouco progresso no comércio ou nas artes das quais ele provém. Os romanos formaram uma república muito aperfeiçoada e exibiram um caráter ilustre; ao passo que, com respeito à propriedade familiar e modo de vida, eles estavam quase na condição de camponeses e lavradores. A política de Esparta surgiu de um princípio diretamente oposto às máximas do comércio e passou a conter e suspender as artes comerciais em todos os seus efeitos. A nação não teria um único cidadão admirado por sua riqueza ou pelos apetrechos de sua pessoa; ele não seria ocupado pelo cuidado com sua subsistência ou fortuna privada; e para alcançar essa dispensa dos homens livres, as leis da natureza e do gênero humano foram recusadas a ponto de condenar, na capacidade de escravos, uma raça particular de homens para desempenharem os trabalhos necessários para a manutenção do povo, não deixando ao cidadão nada mais para se preocupar do que com seu próprio caráter e o serviço de seu país. Foram bem-sucedidos na medida em que, sem riquezas, em meio a nações que admiravam posses e na parte mais cultivada da terra, gozaram de um grau de consideração superior ao que o brilho mesmo de gênio literário e das belas artes, bem como do comércio, conferiram a seus vizinhos (Ferguson, 1792, vol. I, p. 252).

Estabelecendo claramente uma separação entre civilização e comércio, Ferguson pode ampliar o sentido do termo - ainda que mantenha seu caráter relacional com a rudeza (nenhuma nação rude pode ser denominada civilização) - e utilizá-lo "como categoria de crítica social", como afirma Pedro Paulo Pimenta (2013, p. 127). 
[...] muitas vezes preferimos adotar o método que põe tudo na dependência de conjecturas, que imputa cada uma de nossas vantagens às artes que possuímos e que imagina que a mera negação de todas as virtudes seria uma descrição suficiente do homem em seu estado original. Nós mesmos seríamos o suposto padrão de polidez e civilização; e onde os nossos traços não aparecem, consideramos que não haveria nada digno de ser conhecido (Ferguson, 2019, p. 121, grifo nosso).

Assim, a civilização não se identifica necessariamente com o refinamento da sociedade moderna à qual Ferguson se refere ("nós mesmos" alude ao tempo do autor): ele sugere haver padrões para medir o grau de civilização e de polidez diferentes daqueles aos quais sua época está acostumada. Segundo Iain McDaniel (2013), “embora a própria posição de Ferguson não fosse em nenhum lugar contrária ao comércio, como por vezes é defendido, ela representa uma alternativa distintiva no espectro dos escritos escoceses sobre o comércio. Ele rejeitou a identificação entre sociedade comercial e civilização que percebia nos escritos dos seus contemporâneos mais famosos" (p. 96). Com isso, passa a ser possível denominar civilização outras nações polidas que não apenas as nações comerciais europeias. Da perspectiva da teoria dos estágios, é a segunda vez que os seres humanos atingiram um alto grau de refinamento ${ }^{104}$ : não só na modernidade, com os exemplos típicos de Inglaterra e França, mas também na antiguidade, com algumas cidades árabes, além de Grécia e Roma, ou mesmo Esparta.

A reconsideração que Ferguson faz das nações polidas usando como critério o termo civilização tem efeito para sua filosofia política: com isso podemos, mesmo com as enormes diferenças entre as nações refinadas antigas e modernas, utilizar a experiência passada do declínio, sobretudo de Roma, como chave de leitura para pensarmos as ameaças às nações comerciais modernas, cuja fonte de corrupção pode estar refletida, como num espelho, nas narrativas antigas. Esse é o tema do próximo capítulo.

104 "Nesse quadro, o gênero humano ascendeu duas vezes no compasso da história, de começos rudes a elevadíssimos graus de refinamento" (Ferguson, 2019, p. 167). 


\section{Capítulo III}

\section{Filosofia Política}

No segundo capítulo, discutimos a formação da história da sociedade, que é propriamente a história natural da espécie humana. Essa história é pensada em analogia com o progresso do indivíduo, da infância à idade adulta: as sociedades igualmente se desenvolvem de um início primitivo, as nações rudes, até um estágio avançado de civilização, as nações polidas. Esse desenvolvimento é natural e pode ser visto, em sua forma completa, nas porções temperadas do globo terrestre.

Todavia, se o progresso das nações é natural, o mesmo não se pode dizer do declínio. Quando se trata de discutir o fim das nações, a analogia com o indivíduo chega a termo e, logo, deve ser considerado apenas factualmente. Com isso, Ferguson quer evitar tanto uma noção de declínio natural quanto de história cíclica. É por esse motivo que nos capítulos finais do Ensaio, quando Ferguson aborda a corrupção e o declínio, ele o faz através dos casos particulares das nações, não mais sob o conceito geral de sociedade. A elaboração da história da sociedade e a discussão sobre o declínio das nações constituem partes distintas do Ensaio e são mesmo abordadas por meio de diferentes perspectivas: o progresso da sociedade é descrito tendo como base a história natural e a discussão sobre o declínio das nações é uma investigação filosófica, é propriamente a filosofia política.

Ainda assim, da mesma forma que pneumática e filosofia moral estavam imbricadas (como visto no primeiro capítulo), a história da espécie humana e a filosofia política também estão. A elaboração da história da sociedade não é um simples exercício de erudição, ela tem a função de fornecer os elementos factuais que serão o material necessário para o estabelecimento das causas que podem levar uma nação particular a perecer.

Neste capítulo, em um primeiro momento, mostraremos como Ferguson discute o declínio das nações de modo geral, indicando como ele está subsumido à corrupção dos indivíduos. Ora, o Ensaio, ainda que pretenda investigar a sociedade sob bases empíricas, é uma obra com um claro viés moral, e como tal, relaciona tanto a virtude à felicidade nacional quanto a corrupção ao declínio. Para o autor, se a felicidade nacional consiste na união virtuosa de um povo que trabalha tendo em vista o bem de sua comunidade (a virtude individual principal, como vimos no primeiro capítulo, é descrita como o amor ao 
gênero humano ou benevolência), o declínio está ligado ao seu oposto, ou seja, ao relaxamento desse espírito nacional, que é a própria corrupção dos indivíduos. Em seguida, trataremos de dois casos particulares: Roma e as nações comerciais modernas (mais especificamente a Inglaterra). A história de Roma é o caso ideal, pois permite ao filósofo político pensar, em retrospectiva, as causas que determinaram a corrupção dos romanos e a ruína da República para assim projetar, em perspectiva, as ameaças a que estão sujeitos os Estados europeus da modernidade. Esse método comparativo de investigação só é possível porque ambas são nações avançadas, ou seja, estão compreendidas igualmente no que o autor denominou estágio polido. Por fim, tentaremos deixar claro como Montesquieu influenciou sobremaneira a filosofia política de Ferguson, no que diz respeito às suas considerações sobre a história de Roma e no que concerne à sua teoria das formas de governo.

\section{III.i. História e filosofia}

Como vimos, em parte do Ensaio Ferguson se propõe a elaborar uma história natural da sociedade. Essa história, história da espécie, ainda que indiciária, toma como material as diversas histórias particulares; nesse ponto, Ferguson une história factual e narrativa (ou civil) e história descritiva (ou natural), a fim de ordenar e classificar a pluralidade dos eventos humanos, em um modelo de estágios de desenvolvimento. A história do progresso da sociedade civil faz um contraponto à história hipotética construída por Rousseau; o genebrino afirma não se fiar em "verdades históricas", mas em "raciocínios hipotéticos e condicionais" (Rousseau, 2002, pp. 161-162).

No entanto, podemos perguntar se a elaboração da história natural da sociedade se restringe a si mesma, ou, nas palavras de Bertrand Binoche (2013), resta "saber em que medida a história natural tem um significado, se ela responde a um desígnio qualquer ou se se trata somente de apreciá-la como a uniformização abstrata de simples regularidades contingentes" (p. 110, grifo nosso).

Na verdade, defendemos que a história natural da sociedade tem como finalidade servir de material para que o autor possa estabelecer regras gerais para o homem e para a sociedade - no Ensaio, principalmente para sua filosofia política, que trata dos motivos que podem levar uma nação à corrupção e ao declínio. Nossa ideia está fundamentada no propósito baconiano de construção de uma história natural "adequada para servir como 
base e fundamento da verdadeira filosofia" e na apropriação que Ferguson faz dele, de modo muito explícito, nas Instituições de Filosofia Moral.

Para retomarmos o projeto de Bacon, voltemos à subdivisão que o autor faz do conhecimento: "as partes do conhecimento humano fazem referência às três partes do entendimento humano, que é a sede do saber: a História à sua Memória, a Poesia à sua Imaginação e a Filosofia à sua Razão" (Bacon, 2007, p. 112). Posteriormente, estabelece uma hierarquização desses saberes, em que a filosofia é amparada pela história na obtenção de material para seus raciocínios:

História natural, como dissemos, tem três objetos, mas dois usos. É usada para o conhecimento das coisas que estão comprometidas com a história ou é usada como matéria primeira da filosofia e o objeto e material da verdadeira indução. O último uso está agora em discussão; neste momento, quero dizer, e nunca antes disso. Pois nem Aristóteles, nem Teofrasto, nem Dioscórides, nem Caio Plínio, muito menos os modernos, jamais sugeriram esse propósito (sobre o qual eu discorro) para a filosofia natural (Bacon, 2014, p. 229).

O projeto reformador de Bacon tem como objetivo uma nova interpretação da natureza baseada na experiência; no entanto, não se trata de um tipo empírico qualquer de teoria do conhecimento, pois o autor considera os dados da experiência sensível por si sós duvidosos - ele próprio adverte que o empirismo dos antigos e dos modernos é uma filosofia que gera dogmas “deformados e bizarros" (Bacon, 2014, p. 64). Bacon propõe, então, correções para transformar esse modelo deformador no verdadeiro método de interpretação da natureza. Em primeiro lugar, é preciso corrigir as limitações e enganos dos sentidos. Bacon diz que "toda interpretação da natureza, que tenha a mínima chance de ser verdadeira, é obtida por instâncias e experimentos adequados e relevantes, nos quais os sentidos apenas julgam o experimento, enquanto a experiência julga a natureza e a coisa em si" (Bacon, 2014, p. 58, grifo do autor). Dessa forma, e em segundo lugar, a introdução dos experimentos adquire uma importância fundamental já que terão a função de modelar a experiência, provocando a natureza a se revelar, ou, como afirma Didier Deleule (2010), “podemos, se quisermos, afirmar que a via aberta por Bacon é aquela do domínio do terreno da experiência pelo desenvolvimento sistemático e imaginativo da experimentação" ( p. 87).

Porém, não basta simplesmente aumentar o número de experimentos para termos mais material disponível, é preciso que a experimentação não seja tateante, pois "o método de experimentação atualmente utilizado pelos homens é cego e estúpido. 
Consequentemente, conforme eles vagueiam e se perdem em um caminho nada claro, apenas tomando como guia as coisas que encontram pelo caminho, eles andam para lá e para cá e fazem pouco progresso" (Bacon, 2014, p. 69). É preciso transformar os experimentos acidentais em experimentos propostos e intencionais; e esse material obtido por um novo plano de observação e experimentação será descrito, classificado e ordenado para compor a história natural. Assim, há uma diferença crucial entre "o método de uma história natural feita para si mesma" e "o método da história natural recolhida para informar o entendimento com o objetivo de fundar uma filosofia” (Bacon, 2014, p. 91). O projeto de Bacon não só dá um novo estatuto à história natural, mas propõe construí-la a partir mesmo desse propósito. Aristóteles, por exemplo, escreveu a História dos animais, porém, de acordo com Bacon, sem essa perspectiva, sem tomar os dados da história como material para a indução de axiomas. Na verdade, a crítica de Bacon a Aristóteles é exemplar, pois se trata de um caso típico de teoria "construída sobre uma base excessivamente estreita de experimentos e histórias naturais” (Bacon, 2014, p. 63). Ainda que Aristóteles tenha escrito história natural, não tomou as precauções necessárias para basear seus axiomas nos dados coletados, nem se certificou de que eram suficientes para tal; sobre isso, Bacon afirma que:

[...] ninguém deve ficar impressionado ao se deparar, muitas vezes, nos livros Sobre os animais, Problemas e em outros tratados com discussões sobre experimentos. Pois ele, de fato, tirava conclusões de antemão e não consultava devidamente a experiência como base de suas decisões e axiomas; depois de tomar suas decisões de forma arbitrária, ele exibia seu experimento distorcido para conformar-se às suas opiniões, como quem desfila um escravo (Bacon, 2014, p. 64).

Ora, Bacon atribui grande importância à história natural justamente porque é ela que servirá de material para a indução, que é o método considerado pelo autor no raciocínio filosófico (a história natural é base e fundamento da verdadeira filosofia, segundo subtítulo de Preparação para uma história natural e experimental ${ }^{105}$ ). Mas como se realiza a indução para que resulte em filosofia ou ciência? A verdadeira indução, diz Bacon no Novo Órganon, é um método lento, em que primeiro estabelecemos axiomas intermediários, pois "não devemos permitir o entendimento salte e voe dos particulares aos axiomas remotos e altamente generalizados"; essa ascensão deve ser feita "por uma escala genuína, por etapas regulares, sem lacunas ou rupturas, dos particulares para os

105 Publicado em 1620 no mesmo volume do Novo Órganon. 
axiomas menores e depois para os axiomas intermediários, um acima do outro e, só no final, para o mais geral" (Bacon, 2014, p. 93). Esse processo indutivo não dá conta da totalidade do método baconiano: há também um momento dedutivo, em que partimos desses axiomas encontrados para a obtenção de "novos resultados e experiências" (Bacon, 2014, p. 57).

Ainda que tenha concebido todo esse enredo conceitual, Bacon nunca chegou à Grande Renovação planejada no Novo Órganon e a aplicação prática do seu método não foi levada a cabo. De toda forma, o projeto baconiano foi muito importante para a filosofia posterior. Gladys Bryson (1945), em Man and society, diz que os filósofos escoceses do século XVIII praticaram o método experimental ao tratar do homem e de suas relações sociais: esse "procedimento segundo eles era newtoniano, mas davam crédito pela inspiração, antes de Newton, a Bacon" (p. 18). Como Bryson, Wood diz que "o Iluminismo deveria ser considerado, além de a era de Newton, a era da história natural" (Wood, 1989, p. 89), em razão da influência de Bacon.

Porém, cabe-nos indagar de que forma o método teorizado por Bacon poderia ser aplicado aos fenômenos humanos, na elaboração de uma filosofia moral e política? Antes de tudo, é preciso esclarecer que embora as noções de observação e experimentação tenham sido pensadas mais especificamente para os fenômenos naturais, Bacon, em seu quadro geral da ciência, abrange todo o conhecimento, inclusive do homem, ainda que não tenha de fato sistematizado uma filosofia moral, tampouco uma investigação das sociedades humanas. Também, é importante pontuar que para Bacon a filosofia moral e a filosofia civil ou política não estão conectadas (porque o conhecimento moral é diferente do conhecimento civil). Assim, a filosofia moral, trata do homem em seu aspecto individual e seria dividida, quando completa, em medicina, lógica e ética; por sua vez, a filosofia civil ou política considera o homem em seu aspecto congregado e social. Essa separação poderia resultar em duas maneiras distintas de se pensar a fundamentação de cada uma dessas ciências: para a filosofia moral, a história natural seria mais apropriada, enquanto para a filosofia civil, seria a história civil. Essa é apenas uma especulação baseada em analogia, pois Bacon não explicita como a filosofia política seria abordada, ainda que tenha se dedicado a escrever várias histórias de transações civis (sendo a History of Henry VII a mais importante e completa) ${ }^{106}$.

\footnotetext{
106 Segundo John Tinkler, "na filosofia de Bacon, a história natural tem dois usos, 'tanto em virtude do conhecimento das próprias coisas relacionadas com a história quanto como material primário da filosofia'. Seu segundo uso faz dela ingrediente e material da indução sólida e regrada, e pode ser chamada de progenitora da filosofia' (IV, 298). Ele igualmente argumenta que a utilidade da história do conhecimento seria tal que 'em grande medida auxiliaria o erudito no uso e administração do conhecimento; tal que exibiria os movimento e perturbações, os vícios e virtudes, que acontecem não menos em questões
} 
De forma mais minuciosa, Hume, em sua introdução ao Tratado da natureza humana, faz uma observação sobre a diferença entre os fenômenos naturais em geral e os seres humanos em particular. Ele diz que diferentemente das ciências matemáticas e da natureza, as ciências morais têm como objeto o homem, que no papel de agente da investigação, não é passível dos mesmos experimentos científicos que os fenômenos da natureza. Assim, o filósofo moral (para Hume, como para Ferguson, filosofia moral e política estão conectadas) precisa do material da história, entendida por Hume como história civil, pois, como seu objeto não é um corpo, com o qual se pode "reunir experimentos de maneira deliberada e premeditada", ao modo do filósofo natural, mas sim o homem e seu comportamento, os experimentos possíveis só ocorrem "mediante a observação cuidadosa da vida humana, tomando-os tais como aparecem no curso habitual do mundo, no comportamento dos homens em sociedade, em suas ocupações e seus prazeres" (Hume, 2009, p. 24). Em Hume, por exemplo, a ciência do homem estava baseada na utilização da história como material para a reflexão filosófica ${ }^{107}$. Segundo ele, a história fornece "registros de guerras, intrigas, sedições e revoltas", que "são coleções de experimentos pelos quais o político e o filósofo da moral fixa os princípios de sua ciência, do mesmo modo que o físico ou o filósofo da natureza familiariza-se com a natureza das plantas, dos minerais ou de outros objetos externos, mediante os experimentos que realiza sobre eles" (Hume, 2004, p. 123).

Montesquieu, que Ferguson cita de modo reiterado em sua obra ${ }^{108}$, igualmente valeu-se da história para estabelecer causas gerais em matéria de política.

Não é a sorte que domina o mundo. Podemos perguntá-lo aos romanos, que tiveram uma sucessão contínua de situações ditosas, enquanto se governaram em um certo plano, e uma sucessão ininterrupta de reveses, quando se conduziram com base em outro. Existem causas gerais, seja morais, seja físicas, que atuam em cada monarquia, elevam-na, sustentam-na ou lhe impõe a derrocada; todos os acidentes estão sujeitos a essas causas.

intelectuais do que civis; e que observando-os o melhor sistema de governo seria derivado e estabelecido' (IV, 301). Por analogia, poderíamos dizer que Bacon também considerou a história civil como a fundamentação da filosofia civil’. In.: Peltonen, M. (ed.). The Cambridge Companion to Bacon. Cambridge: Cambridge University Press, 1996, p. 237.

${ }^{107}$ Cf. Phillipson, N. David Hume, The Philosopher as Historian. London: Yale University Press, 1989. 108 "Quando recordo o que o barão de Montesquieu escreveu a respeito, não sei bem explicar por que me dediquei ao estudo das coisas humanas. A verdade é que minhas reflexões e sentimentos me instigam a tal, e julgo-me capaz de enunciá-los mais diretamente para o leitor, pois estou mais próximo do homem comum. Caso o leitor sinta que é necessário, para preparar o caminho para o que se segue a respeito da história geral das nações, uma explicação preliminar dos tópicos sob os quais as variadas formas de governo podem ser classificadas, recomendo-lhe que consulte o que foi dito por esse profundo conhecedor da política e amável moralista. Em seus escritos se encontra o original do que eu digo aqui, e também, provavelmente, a fonte de muitas observações que, em diferentes lugares, posso ter repetido a título de inovação sem citar o autor" (Ferguson, 2019, pp. 107-108). 
Quando o acaso de uma batalha, isto é, uma causa particular, destrói um Estado, é porque havia uma causa geral que fazia com que esse Estado devesse perecer em uma única batalha. Em uma palavra, o rumo principal arrasta consigo todos os acidentes particulares (Montesquieu, 2002, pp. 149-150).

Suas Considerações sobre as causas da grandeza dos romanos e de sua decadência, como o próprio título sugere, buscam estabelecer as causas que engendraram a grandeza de Roma, mas também sua ruína por meio de uma investigação historiográfica. Assim, não se trata somente de narrar a história da República e do Império Romano, mas inclusive de explicar os movimentos (as causas gerais) dos acontecimentos. Nesse pequeno texto, Montesquieu estabelece ainda as bases em que a história poderia ser usada tanto para suas reflexões políticas de modo geral, como para se pensar as questões de sua época.

Primeiramente, Montesquieu mostra que não se podem conciliar trajetórias tão diferentes quanto as das nações antigas e moderna; ora, quando analisamos a história de Roma, estamos diante de questões diferentes não apenas em grau, mas também de natureza, em relação à modernidade. Assim, lê-se inicialmente que "não convém ter da cidade de Roma, em seus primórdios, a ideia que nos dão as cidades que vemos hoje, a menos que se trate das da Criméia, feitas para guardar o butim, os animais e os frutos da campanha" (Montesquieu, 2002, p. 9). Em outro momento, Montesquieu diz que "os romanos, acostumados a desprezar a natureza humana na pessoa de seus filhos e seus escravos, não podiam conhecer a virtude a que chamamos humanidade" (Montesquieu, 2002, p. 116). Muitos outros exemplos são apontados no sentido de tornar evidente a irredutibilidade das experiências antigas e modernas; no entanto, o ponto principal, para Montesquieu, é, com efeito, o desenvolvimento do comércio. É que a proporção e a extensão ${ }^{109}$ do comércio na modernidade não podem ser comparadas a nenhuma situação da antiguidade, ainda que povos como os gregos e os cartagineses e nações como a Arábia e as Índias tenham desenvolvido um comércio baseado no luxo ${ }^{110}$.

\footnotetext{
109 "O comércio antigo que conhecemos, fazendo-se de um porto do Mediterrâneo a outro, estava quase todo no sul. Ora, como os povos do mesmo clima têm mais ou menos as mesmas coisas, não têm tanta necessidade de comerciar entre si quanto os de um clima diferente. Assim, o comércio na Europa era menos extenso outrora do que é hoje" (Montesquieu, 2005, p. 363).

${ }^{110}$ Montesquieu, em $O$ Espírito das Leis, diferencia o comércio baseado no luxo do comércio baseado na economia: aquele é próprio de governos de um só e "seu objetivo principal é dar à nação que o pratica tudo o que puder servir a seu orgulho, a suas delícias e a suas fantasias"; este é próprio de governos de vários e se restringe "à prática de ganhar pouco, e até mesmo de ganhar menos do que qualquer nação, e de só ser compensado ganhando continuamente" (Montesquieu, 2005, p. 346).
} 
O efeito da descoberta da América foi de ligar à Europa a Ásia e a África. A América fornece à Europa a matéria de seu comércio com esta vasta parte da Ásia a que chamamos Índias orientais. A prata, esse metal tão útil para o comércio, como signo, foi também a base do maior comércio do universo, enquanto mercadoria. Enfim, a navegação da África se tornou necessária; fornecia homens para o trabalho das minas e das terras da América. A Europa chegou a um grau tal de poder que a história nada tem de comparável neste sentido, se considerarmos a imensidão dos gastos, a grandeza dos compromissos, o número das tropas e a continuidade de sua manutenção, mesmo quando são mais inúteis e as temos apenas para a ostentação (Montesquieu, 2005, p. 397).

O fato é que juntamente com o comércio há uma suavização das maneiras, uma perfeição das artes e principalmente um incremento de comunicação: assim, com a navegação da África e da América, as nações comerciais modernas se tornaram incomparáveis com os exemplos antigos. É, por essa razão, que Bertrand Binoche (2015) afirma que "dessa vez, não é um modo de comparação que é recusado em benefício de outro, é mesmo toda comparação: literalmente, a extensão moderna do comércio é incomparável. Podemos dizer: algo acontece na história europeia que nenhuma outra história pode oferecer equivalente" (p. 107, grifo nosso).

Ora, mas como Montesquieu pode, ao mesmo tempo em que recusa certa comparação, valer-se da história como material para suas análises políticas? Sua máxima, expressa em $O$ Espírito das Leis (1748), é a de "não ver como semelhantes casos realmente diferentes e não perder as diferenças daqueles que parecem semelhantes" (Montesquieu, 2005, p. 5). É assim que ele, por um lado, rejeita tomar a história antiga como historia magistra vitae ${ }^{111}$, ou seja, utilizar as experiências antigas como modelo de procedimento que poderia ser aplicado indistintamente a qualquer tempo e lugar, e, por outro, admite que, como há regras gerais e fixas da natureza humana, é possível estabelecer paralelos nas diversas trajetórias políticas das nações, justamente porque das mesmas causas sempre surtem os mesmos efeitos:

A história moderna nos fornece um exemplo do que aconteceu em Roma, o que é realmente notável, pois, como em todas as épocas os homens tiveram as mesmas paixões, as ocasiões que produzem as grandes mudanças são diferentes, mas as causas são sempre as mesmas (Montesquieu, 2002, p. 11).

\footnotetext{
111 Segundo Bertrand Binoche, "a grande ingenuidade da historia magistra vitae é a de se fixar em semelhanças aparentes, sobrepondo-as apressadamente; se a ela é atribuída, assim, uma função exemplar, é porque ignora as diferenças reais que a análise abstrata da natureza das coisas tem somente o privilégio de torná-las perceptíveis" (pp. 117-118).
} 
Assim, restabelecido o estatuto da história, nas Considerações, Montesquieu pode de fato pensar a experiência das nações modernas, principalmente da Inglaterra e da França, a partir do exemplo romano, de sua grandeza na República e de sua decadência no Império ${ }^{112}$.

\section{III.ii. História: progresso e virtude}

Como foi dito, tanto Bacon, como Montesquieu e Hume teorizaram, cada qual à sua maneira, um método em que a história civil ou particular seria fonte de material factual para se pensar questões políticas. Nesse sentido, torna-se curioso o fato de que Ferguson, em direção oposta, tenha preferido elaborar uma história natural da sociedade para tal função. Ferguson parece ter preferido esse expediente com vistas a resolver o problema da comparação histórica colocado por seus antecessores. Com esse modelo, como exposto no capítulo anterior, nosso autor pôde, a um só tempo, afirmar a irredutibilidade das experiências antigas e moderna, seguindo os passos de Montesquieu, e compará-las entre si a fim de estabelecer regras gerais para sua filosofia política; ou seja, a história da sociedade, principalmente porque ela contém uma teoria de estágios ${ }^{113}$ de desenvolvimento capaz de organizar as diversas histórias particulares, permite reunir em um único estágio - o estágio polido ou da sociedade civil - nações antigas, principalmente Grécia, Esparta e Roma, e as nações comerciais modernas, sobretudo Inglaterra e França.

$\mathrm{Na}$ verdade, ainda que haja uma diferença metodológica, nesse quesito, entre Ferguson e Bacon, Montesquieu e Hume, a história natural aplicada às questões humanas foi um expediente historiográfico comum a vários outros filósofos escoceses da época (Adam Smith, John Millar, Lord Kames, entre outros) e foi denominado, por Dugald Stewart, "história teórica ou conjectural":

\footnotetext{
112 Sobre a relação entre política e história em Montesquieu, cf. Dedieu, J. Montesquieu et la tradition politique anglaise en France: les sources anglaises de L'Esprit de lois. Victor Lecoffre, 1909 e Althusser, L. Montesquieu, la politique et l'histoire. Paris: Presses Universitaires de France, 1959.

113 Admitimos, como Berry (2013), que a teoria dos quatro estágios é "um exemplo de "história natural"", e, mais ainda, que a história natural é propriamente a história "conjectural ou teórica" denominada por Dugald Stewart em seu Account of the Life of Smith. Cf. Berry, C. The idea of commercial society in the Scottish Enlightenment. Edinburgh: Edinburgh University Press, 2013, p. 32 e seguintes.
} 
Quando examinamos a história da humanidade, bem como quando examinamos os fenômenos do mundo material, e não podemos traçar o processo pelo qual um evento foi produzido, é geralmente importante que sejamos capazes de mostrar como ele deve ter sido produzido através de causas naturais. Assim, no exemplo sugerido nestas observações, embora seja impossível determinar com certeza quais foram os passos que uma língua particular se formou, ainda, se podemos mostrar, por meio dos princípios conhecidos da natureza humana, como todas as suas partes devem ter aparecido gradualmente, a mente não é somente satisfeita de certa forma, mas também uma restrição é dada àquela filosofia indolente que chama de milagre quaisquer aparências, tanto do mundo natural quanto moral, as quais é incapaz de explicar. Esse tipo de investigação filosófica, que não tem nome apropriado em nossa língua, eu tomo a liberdade de intitular História Teórica ou Conjectural, expressão que coincide bastante em seu significado com aquela empregada por Hume, História Natural, e com o que alguns escritores franceses chamaram de História Refletida (Smith, 1811, vol. V, pp. 449-450, grifos do autor).

Assim, a história conjectural ou teórica, ou mesmo natural, como afirma Stewart, embora utilize como fonte de conhecimento a observação e exame dos fenômenos, possibilita que sejamos capazes de discutir também alguns fenômenos que não estão acessíveis ou cujas causas nos são desconhecidas, ou seja, é um método que, para usar as palavras de Diderot no verbete da Enciclopédia relacionado à História Natural, "na falta do conhecimento das coisas, que só se adquire vendo-as com frequência e observando-as com exatidão, esforçamo-nos por nos instruir por antecipação, sem ter visto nem observado: complementa-se a inspeção dos objetos reais pelo enunciado de algumas de suas qualidades" $" 114$. Trata-se, portanto, de uma investigação filosófica: Ferguson e seus contemporâneos eram, antes de tudo, filósofos que pretendiam estabelecer regras gerais para a sociedade humana, e o que garantia a possibilidade de fazer conjecturas quando da falta de informação proveniente da história factual era, segundo Stewart, "os princípios conhecidos da natureza humana" (Smith, 1811, vol. V, p. 450).

Em Ferguson, mais especificamente, a história natural ou conjectural da sociedade é elaborada a partir de uma noção de progresso que é natural tanto ao homem individual quanto à sua espécie. Dado que a história da sociedade é exatamente a história da espécie, esse progresso é o desenrolar gradual de estágios sociais denominados selvagem, bárbaro e polido. Essas categorias são tipos ideais que permitem dar inteligibilidade à variedade de fenômenos observados na história da humanidade; mais

${ }^{114}$ Diderot, D. Enciclopédia, ou Dicionário razoado das ciências, das artes e dos ofícios. Volume 3: Ciência da Natureza. Organização e tradução Pedro Paulo Pimenta e Maria das Graças de Souza, São Paulo: UNESP, 2015, p. 233. 
ainda, elas fixam certas semelhanças das nações, sem com isso excluir a diversidade particular. Para o autor, a história da sociedade é mesmo a interrelação entre a regra geral (a história indiciária) e os casos particulares (a história factual).

Como dissemos, o progresso, sendo natural, torna a passagem de um estágio a outro necessária; porém, há causas circunstanciais que podem "contrariar a efetividade da regra" (Gautier, 2011, p. 64). Assim, se a história em estágios pressupõe uma necessidade, segundo Claude Gautier, "importa então qualificar o modelo e ter em conta as circunstâncias que respaldam as exceções" (p. 64). Existem algumas causas físicas, como o clima, o solo e outras variantes que podem retardar ou mesmo impedir o progresso de certos povos. Para ilustrar o modo como as exceções se relacionam com a regra (modelo) no caso do progresso da sociedade, podemos utilizar, em analogia, um exemplo que Ferguson cita nos Princípios, quando diferencia os seres estacionários dos seres progressivos; de acordo com o autor, "um bloco de pedra, depois de extraído da pedreira, pode receber, nas mãos do artesão, qualquer variedade de forma, mas deixado por si mesmo, permaneceria no mesmo estado. Uma plântula, ao contrário, em solo favorável e exposto, enraíza e cresce por si mesmo" (Ferguson, 1792, vol. I, p. 190, grifo nosso). Quer dizer, tal como as plantas só realizam sua natureza progressiva em condições favoráveis, também os homens, e por extensão sua sociedade, precisam de certas circunstâncias para progredir.

No entanto, como os homens ocupam um lugar particular na cadeia dos seres, ou seja, são dotados de inteligência, não apenas causas físicas se fazem presentes no progresso de sua sociedade, mas principalmente causas morais que respondem, senão pelo progresso, pela grandeza nacional, ou pelo seu oposto, a ruína. A história da sociedade nos permite estabelecer essas causas.

Essa história nos mostra que os homens são sociáveis, mas a união dos povos em clãs, cidades e nações depende igualmente da rivalidade com os vizinhos. O que dá forma aos agrupamentos humanos é simultaneamente o consenso e o dissenso, quer dizer, a propensão dos homens a se unir a outros na mesma medida que a propensão ao conflito com os demais. Para Ferguson, a rivalidade, ao invés de criar uma cena de todos contra todos, como em Hobbes ${ }^{115}$, vincula os homens à sua comunidade e faz surgir as nações. Nos selvagens, essa dupla tendência é vista na sua forma mais primitiva, já que se relacionam exclusivamente por sentimentos de amizade e inimizade. Os bárbaros, por

\footnotetext{
115 No Leviatã, Hobbes diz que "durante o período em que os homens vivem sem um poder comum para mantê-los em reverência, encontram-se naquela condição denominada guerra; e tal guerra é de todos contra todos" (Hobbes, 1998, p. 84).
} 
conhecerem a propriedade e a subordinação, têm os laços sociais menos estreitos e já possuem, senão leis formais, regras e costumes para mediar suas relações. Segundo Ferguson, os bárbaros são povos belicosos, mas essa sua energia ${ }^{116}$ para a guerra, longe de ser considerada perigosa, pode ter uma conotação positiva, pois o vigor com que rivalizam entre si garante que permaneçam unidos. É que uma das principais características da natureza humana é a atividade, e as guerras podem servir de ocupação ao seu espírito. No Ensaio, lemos que "o homem não é feito para o repouso. Cada uma de suas qualidades amáveis e respeitáveis é um poder ativo, e apenas seus esforços são dignos de louvor" (Ferguson, 2019, p. 292).

Porém, não somente a guerra fornece uma ocupação para um povo; mesmo porque, para Ferguson, "as nações variam quanto à extensão, ao número de habitantes, à riqueza, e também às artes que praticam e às comodidades que adquirem" (Ferguson, 2019, p. 99). Em seu estágio mais avançado de desenvolvimento, as nações fornecem aos homens maior diversidade de ocupações, pois "são mais ricas e praticam artes mais variadas do que as rudes" (Ferguson, 2019, pp. 99-100). No entanto, nem todas as atividades concorrem para a felicidade do indivíduo; segundo o autor: "a felicidade dos homens consiste nas bênçãos de um espírito cândido, ativo e resistente" (Ferguson, 2019, p. 100). As definições de felicidade e de virtude, como foram abordadas no primeiro capítulo, concordam entre si: a felicidade individual se resume na recomendação das virtudes capitais, ainda que com maior ênfase na probidade ou amor ao gênero humano. Há, também como já foi visto, uma relação intrínseca entre a felicidade do indivíduo e a felicidade nacional. Para retomamos a questão, analisemos uma passagem do Ensaio sobre a felicidade nacional:

Não é difícil conciliar os interesses da sociedade aos de seus membros. Se o indivíduo deve toda consideração à comunidade, ele recebe em troca, ao prestá-la, a maior felicidade de que sua natureza é capaz; e a maior bênção que a comunidade poderia dar a seus membros é mantê-los ligados a ela. É assim o Estado mais feliz, o mais amado por seus súditos; e são mais felizes os homens cujo coração se engaja junto à comunidade, na qual encontra todos os objetos de generosidade e zelo, e um escopo para o exercício de cada talento e disposição virtuosa (Ferguson, 2019, pp. 98-99).

\footnotetext{
${ }^{116}$ Foi a partir dessa concepção que Pocock viu na energia ativa de Ferguson a virtù de Maquiavel, e afirmou, com demasiado exagero, que o Ensaio "talvez fosse a investigação escocesa mais maquiaveliana" (Pocock, 1975, p. 497). Segundo Pocock, Ferguson "enfatizava o vigor bárbaro do homem primitivo - ou, ao contrário, confrontado pela fórmula de Tácito de que o selvagem alternava entre uma energia explosiva e paroxismos de indolência, ele enfatizou aquilo que tal ser poderia fazer em seus períodos maníacos; e, uma vez que seu estudo começa com a virtù - pois é esse um dos significados do termo - não foi com surpresa que terminou com um retrato da corrupção" (Pocock, 1999, p. 331).
} 
Portanto, uma nação dita feliz não apenas fornece uma ocupação qualquer a seus membros, mas os engaja na busca do bem comum e os mantém, dessa forma, unidos. Essa concepção de nação atrela seu êxito à união e à atividade em prol da comunidade, excluindo qualquer referência a riquezas, extensão ou número populacional ${ }^{117}$, pois a grandeza" de uma nação está na sua capacidade de "melhorar as disposições originais da natureza humana" (Ferguson, 2019, p. 287), que dizem respeito à preservação e ao aperfeiçoamento moral. É exatamente nesse cenário que uma nação tem mais condições de prosperar; segundo Ferguson, "em épocas de atividade e vigor", o gênero humano é capaz de levar "a grandeza nacional a alturas que nenhuma sabedoria humana poderia ter antecipado" (Ferguson, 2019, pp. 370-371).

No entanto, prosperar ou engrandecer não é o mesmo que progredir, no sentido que o progresso tem no modelo teórico de Ferguson. Muitas nações podem avançar de um estágio a outro sem que sejam necessariamente virtuosas, pois cada estágio é definido a partir de características comuns alheias às de felicidade nacional, como conhecimento da propriedade e da subordinação, desenvolvimento de instituições políticas e sistema de leis e prática das artes em geral. Dessa forma, quando se trata de atribuir valor a uma nação, com vistas à sua felicidade, é mais apropriado usar o termo civilização do que a denominação do estágio mais avançado, estágio polido ou comercial, pois este é apenas um expediente categórico e, portanto, neutro em termos valorativos. Isso quer dizer que podemos estabelecer a felicidade nacional como causa da grandeza ou civilização, mas não do progresso. É que toda nação virtuosa progride, mas nem toda nação que progride é virtuosa; por esse motivo, encontramos, no Ensaio, diversas passagens em que Ferguson parece igualar progresso e grandeza nacional. Mesmo assim, uma nação que progride não pode ser completamente corrupta, caso contrário tenderia à ruína. Se não se pode relacionar formalmente virtude e progresso, pode-se ao menos estabelecer uma relação entre corrupção e declínio.

\footnotetext{
117 "Se considerarmos o estado de sociedade como aquele a que o gênero humano é levado por suas propensões, a ser valorizado pelo efeito que tem na preservação da espécie, no amadurecimento de seus talentos e no despertar de suas virtudes, não teremos de ampliar nossas comunidades para desfrutar dessas vantagens, pois com frequência elas são obtidas, em boa medida, onde nações pouco extensas permanecem independentes entre si" (Ferguson, 2019, p. 100).

118 A grandeza é pensada como sinônimo de eminência, quando Ferguson se refere à grandeza territorial, em geral ele diz extensão territorial.
} 


\section{III.iii. Corrupção e declínio}

Nos Princípios, Ferguson afirma que "naturezas progressivas estão sujeitas a vicissitudes de avanço e declínio, mas não são estacionárias quiçá em nenhum período de sua existência. Assim, no mundo material, indivíduos organizados, sendo progressivos, quando cessam de avançar, começam a declinar, embora insensivelmente no momento de sua transição de um para outro" (Ferguson, 1792, vol. I, p. 190). Visto que há um movimento análogo entre os seres progressivos e a sociedade humana, estas estariam igualmente sujeitas ao declínio, não somente no período mais avançado de seu progresso, mas em qualquer outro momento. Essa comparação, assim ampliada, tornaria não somente o progresso natural e necessário, mas também o declínio:

Tais fenômenos levaram à percepção generalizada de que o progresso das sociedades rumo ao ápice da chamada grandeza nacional seria tão natural quanto é necessário e inevitável o seu retorno à debilidade e obscuridade. Imagens de juventude e velhice são aplicadas às nações, e supõe-se que as comunidades, a exemplo dos indivíduos humanos, teriam um período de vida e uma duração determinada, eventualmente prolongada por poderosos fatores uniformes ou abreviada pelo desgaste, que, levando ao momento fatal, permitiria que o estandarte fosse passado à frente, para que outras nações ascendam e ocupem seu lugar. Políbio afirmou que Cartago, que era muito mais velha que Roma, percebeu muito anteriormente sua decadência; e a vencedora também, pressupôs ele, trazia em si as sementes de sua própria mortalidade (Ferguson, 2019, p. 291).

Porém, quando se trata da sociedade, há, de acordo com Ferguson, uma ruptura com a analogia com o indivíduo:

É uma imagem apropriada, e sua aplicação à história humana se tornou familiar. Mas deve ser óbvio que nações são muito diferentes de indivíduos. A estrutura humana tem um curso geral determinado: em todos os indivíduos, é frágil e tem duração limitada; o exercício a desgasta, a repetição de funções a exaure. Em uma sociedade, porém, os membros que a constituem são renovados a cada geração, a raça como que desfruta de uma juventude eterna, as vantagens são cumulativas e não há paridade com as debilidades típicas da velhice (Ferguson, 2019, pp. 291-292).

Ainda que "uma percepção generalizada" e "uma imagem apropriada", a comparação entre o período de vida dos indivíduos e da sociedade não é possível: as nações não têm necessariamente uma "duração limitada", pois não estão sujeitas a um 
desgaste natural como os indivíduos; elas têm, ao contrário, sua juventude renovada eternamente, a cada nova geração. Com essa afirmação, afasta-se a noção de que a sociedade seria como um corpo natural que deve necessariamente morrer ${ }^{119}$. Esse padrão de um declínio inevitável pode levar à crença de uma história cíclica, que o autor recusa veementemente. A ideia de uma história cíclica estava presente tanto na filosofia estoica quanto de Maquiavel, para quem as sociedades estavam sujeitas a períodos de crescimento e declínio. Para Ferguson, ao contrário, a história da sociedade, enquanto processo natural, só pode ser descrita como história do progresso; o declínio, não sendo necessário, é um mero fato histórico ${ }^{120}$. É por esse motivo que, para discutir o declínio, ou melhor, para estabelecer suas causas, Ferguson põe fim à elaboração da história natural da sociedade e passa a considerar, não mais a sociedade, enquanto abstração das trajetórias semelhantes das nações, mas suas próprias histórias particulares: neste momento, trata-se do declínio das nações e não da sociedade. No Ensaio, as partes finais dedicadas ao tema da corrupção e do declínio são a filosofia política propriamente dita.

Mesmo que não estejamos mais no domínio da história da sociedade, ela foi importante metodologicamente para que se pudesse, primeiramente, pensar as características da natureza humana que levam os homens a se unirem em famílias, clãs ou nações; depois, estabelecer as causas que tornam essas comunidades virtuosas, ou seja, as causas da felicidade nacional. Como vimos, o que mantém os homens inicialmente unidos entre si são os sentimentos de afeição mútua e contenda com inimigos externos, o que resulta em um engajamento ativo e vigoroso às questões da comunidade. Ademais, nas nações rudes, a "política doméstica" padece de muitos "inconvenientes e reveses" e "toda arte é imperfeita e suscetível a muitos aperfeiçoamentos", por isso os bárbaros são movidos por "uma avidez impaciente que os leva a propor reformas e novas instituições que lhes dão esperanças de felicidade nacional” (Ferguson, 2019, p. 297). Como "o

\footnotetext{
119 Segundo George Hildebrand, em sua introdução à coletânea The ideia of progress: A collection of reading, "em suas várias formas clássicas, a ideia de ciclos implicava um profundo pessimismo sobre o futuro. Se o mundo fosse orgânico e mortal, em última análise deve morrer. Se as instituições humanas ou a sociedade fossem também orgânicas e mortais, por fim elas também deveriam sofrer a decadência e finalmente extinguir-se. Se, ademais, a natureza fosse em essência meramente uma repetição sem fim e ordenada de ciclos de mudança, como Aristóteles sugeriu (384-322 AC), então os assuntos humanos como uma parte da natureza não poderia manifestar qualquer tendência permanente em direção tanto à melhoria quanto à degeneração. $\mathrm{Na}$ interpretação estoica dessas ideias, a reposta apropriada era a resignação ou aceitação das leis inexoráveis da natureza", em: Teggart, F. J., The Idea of Progress: A Collection of Readings, Revised Edition, G. H. Hildebrand (ed.), Berkeley, CA: University of California Press, 1949, p. 7.

${ }^{120}$ Nossa posição se contrapõe à leitura de Istvan Hont (1983), para quem Ferguson tinha uma concepção de "declínio inevitável": "Assim, enquanto Ferguson profetizou um declínio inevitável, principalmente como resultado da separação entre o político e o soldado, sua discussão sobre o comércio e o crescimento de riquezas não continha qualquer sugestão de limite dos mecanismos do próprio comércio" (p. 296).
} 
homem não é feito para o repouso" (Ferguson, 2019, p. 292), tais exercícios são como molas a impulsionar o progresso:

Poderíamos imaginar que, em épocas de progresso, a raça humana teria o mundo aberto diante de si, a cada passo uma novidade, como batedores em busca de terras férteis. Desbrava novos terrenos com alegria e expectativas, dedica-se a cada empreitada com o ardor de homens que acreditam estar às portas da felicidade nacional e da glória permanente, e, na esperança de um êxito futuro, se esquece de decepções passadas. Por mera ignorância, espíritos rudes são intoxicados por todas as paixões e, parciais quanto à própria condição e a seus objetivos, pensam que qualquer outra situação é inferior àquela em que se encontram. Excitados em igual medida pelo sucesso e pelo infortúnio, são sanguíneos, ardentes e precipitados, e legam às eras mais instruídas que os sucedem monumentos de execução imperfeita e artes rudes em todos os gêneros, mas deixam também marcas de um espírito vigoroso e ardente, que seus sucessores nem sempre conseguem sustentar ou emular (Ferguson, 2019, p. 298).

Nesse cenário de intensa atividade e paixão, parece ser o progresso a ditar a sorte das nações, e apenas uma calamidade externa, como uma guerra de grandes proporções, poderia pôr fim a essa trajetória ${ }^{121}$. Portanto, se se atribui a prosperidade "ao afeto e a força de espírito, que são os laços e a força das comunidades, são inspirações divinas e atributos originais da natureza humana" (Ferguson, 2019, p. 287), seus opostos, o relaxamento e a fraqueza ${ }^{122}$, seriam os responsáveis pela ruína das nações ${ }^{123}$.

$\mathrm{Na}$ verdade, o relaxamento e a fraqueza ou perda do vigor ou espírito nacional são a própria definição de corrupção. Segundo Claude Gautier (2011), "Ferguson faz uma

\footnotetext{
${ }^{121}$ Ainda assim, essa máxima é passível de exceções; no Ensaio, lemos: "Contudo, a história do gênero humano mostra que corrupção nesse ou em qualquer outro grau não é algo peculiar a nações em declínio, tampouco resultado de uma prosperidade conspícua e de grandes avanços nas artes comerciais. Na infância das instituições, os laços sociais costumam ser fortes, e os súditos, seja por ardente devoção a sua tribo, seja por acintosa animosidade contra um inimigo (e em ambos os casos por uma coragem veemente), estão aptos a urgir à defesa da fortuna de uma comunidade em crescimento. No entanto, o selvagem e o bárbaro deram alguns exemplos de nações inteiras com caráter fraco e medroso. Ainda mais comum é encontrar exemplos que se encaixam nos casos de corrupção que descrevemos ao tratar de nações bárbaras, que fizeram da rapina, para além de uma prática de guerra, o seu comércio, não com vistas ao enriquecimento da comunidade, mas à preferência por coisas, como propriedade, em detrimento aos laços de afeto ou de sangue" (Ferguson, 2019, p. 332).

122 "O gênero humano, quando degenera e tende à ruína, assim como quando se aprimora e adquire vantagens substanciais, procede a passos lentos, quase imperceptíveis. Se, em épocas de atividade e vigor, levam a grandeza nacional a alturas que nenhuma sabedoria humana poderia ter antecipado, em épocas de relaxamento e fraqueza eles incorrem em muitos males que seus temores não haviam sugerido e que consideravam como improváveis, na onda de sucesso e prosperidade em que se encontravam" (Ferguson, 2019, pp. 370-371).

123 "Se a força de uma nação consistir de homens nos quais possa confiar, e que se combinam, deliberadamente ou não, de maneira propícia para a sua preservação, segue-se que as maneiras são tão importantes quanto o número de homens e sua riqueza, e a corrupção delas deve ser considerada como a principal causa do declínio e da ruína de uma nação" (Ferguson, 2019, p. 327).
} 
ligação entre o declínio das nações e a corrupção dos indivíduos" (p. 93). Isso significa que, antes de tudo, é preciso encontrar as causas da corrupção dos homens, para com isso estabelecer de que forma as nações podem declinar. Em primeiro lugar, é preciso recordar que o homem tem uma estrutura que "exige que ele permaneça ocupado" (Ferguson, 2019, p. 293) e, ao contrário do que vulgarmente se entende, sua verdadeira felicidade está em seus esforços, na busca pela satisfação de suas necessidades, não na própria satisfação destas. No Ensaio, lemos que "as virtudes dos homens reluzem mais durante suas lutas, não após a realização de seus objetivos" (Ferguson, 2019, p. 288). Logo, é de se supor que os homens, em seu estágio rude, são menos suscetíveis ao relaxamento e à fraqueza, uma vez que estão em constante guerra com seus vizinhos e esforçando-se para remediar os “inconvenientes e reveses” de sua condição (Ferguson, 2019, p. 297), e que, portanto, a corrupção dos indivíduos é um perigo a ameaçar as nações polidas ou comerciais. Ferguson coloca a questão como um paradoxo: por um lado, é a virtude que faz com que as nações progridam e alcancem a grandeza ${ }^{124}$, por outro, pode ser essa mesma grandeza ou eminência a responsável pela "obscuridade" e "fraqueza":

Caso se verificasse que há nações que avançaram a partir de primeiros rudimentos até chegar à posse das artes que asseguram o domínio sobre outras e que souberam preservar essas vantagens em proporção à qualificação que as levou a adquiri-las, e, ainda, que essas mesmas nações se mantiveram em um curso de felicidade ininterrupta até ser destruídas por calamidades externas, retendo sua força até que um poder mais afortunado e vigoroso viesse a enfraquecê-la, então o objeto sobre o qual aqui especulamos não apresentaria grandes dificuldades nem daria lugar a muitas reflexões. Quando, porém, observamos em tantas nações uma espécie de retorno espontâneo à obscuridade e à fraqueza, e a despeito de advertências quanto aos perigos em que podem incorrer, elas se deixam submeter ora por poderes com que antes não teriam condições de competir, ora por forças que se acostumaram a negligenciar e a desprezar, o objeto se torna mais interessante, e sua explicação, mais difícil (Ferguson, 2019, p. 290).

Ferguson, neste momento, fala da eminência ou grandeza nacional como o avanço que decorre "de um curso de felicidade ininterrupta" a partir de "primeiros rudimentos", quer dizer, trata-se, de fato, das nações em seu estágio polido ou comercial. Assim, a questão é de difícil explicação porque não é uma "calamidade externa" que parece pôr fỉm a uma nação avançada, mas problemas internos à sua própria grandeza.

124 "A riqueza, a grandeza e o poder das nações costumam ser efeitos da virtude, e a perda dessas vantagens é geralmente uma consequência do vício” (Ferguson, 2019, p. 288). 
No entanto, a ponderação de que é "uma espécie de retorno espontâneo" deve ser feita, pois senão voltaríamos à ideia de uma história cíclica e de um declínio tão natural quanto o próprio progresso. Com efeito, como o declínio é contingente, a grandeza não pode ser sua causa necessária, é apenas um fato "conhecido por uma variedade de exemplos" (Ferguson, 2019, p. 290). Ainda assim, podemos estabelecer características comuns que levam nações eminentes ao declínio, quer dizer, é possível determinar quais são suas causas circunstanciais.

Na quinta parte do Ensaio, "Sobre o declínio das nações", Ferguson lista várias causas que podem levar uma nação à ruína. Essas razões podem ser reunidas em dois grupos, aquelas que causam o relaxamento do espírito nacional, e aquelas que levam ao desperdício dos recursos nacionais. A primeira, mais importante e tema principal de Ferguson, trata de questões relacionadas à corrupção dos indivíduos; a segunda, sobre a riqueza nacional, ainda que de forma muito breve e marginal, discute as circunstâncias em que o desperdício dessa riqueza pode levar uma nação à ruína.

De acordo com Ferguson, são muitas as razões que podem causar o relaxamento do espírito nacional. Antes de tudo, é preciso considerar que os homens são suscetíveis a passar naturalmente de períodos de intenso ardor para outros de grande remissão ${ }^{125}$, quer dizer, uma das razões para certos intervalos de langor "pode ser extraída da volubilidade e inconstância do gênero humano" (Ferguson, 2019, p. 293). Outro motivo, neste caso circunstancial, são os efeitos que podem decorrer do desenvolvimento das artes comerciais e lucrativa. Em primeiro lugar, a riqueza, sobretudo o luxo, que resultam desse desenvolvimento tende a confundir os homens, fazendo-os crer que objetos alheios à verdadeira virtude, como distinção e fortuna, lhes trarão felicidade. Com isso, ao invés de buscarem, com suas ocupações, o bem da comunidade, eles passam a visar apenas o enriquecimento individual, movidos por um "desejo pelo lucro" que "sufoca o amor à perfeição" (Ferguson, 2019, p. 302). Igualmente, o avanço dessas artes depende de uma separação de cada atividade específica da produção e das profissões de maneira geral. Essa separação das artes e das profissões faz com que os homens se dediquem a uma

\footnotetext{
125 "Um povo, a exemplo dos indivíduos de que é composto, atua sob a influência de humores passageiros, esperanças sanguíneas, animosidades veementes. Ora dispõe-se a entrar em contendas nacionais, ora a trocá-las pela lassidão e pelo tédio. Em seus debates e contendas civis, podem ser ardentes ou indiferentes. Paixões epidêmicas emergem ou arrefecem por razões que podem ser triviais ou importantes. Partidos escolhem seus nomes e declaram suas intenções por mero capricho ou acidente, e omitem-se nas ocasiões mais momentosas. Se uma veia de gênio literário se abre por acaso ou tem início uma investigação inédita, de súbito as descobertas, verdadeiras ou não, se multiplicam, e a conversação se torna inquisitiva e animada. Se uma nova fonte de riqueza é encontrada ou abre-se uma perspectiva de conquista, a imaginação dos homens se inflama, e partes inteiras do globo se envolvem em aventuras nocivas ou bem-sucedidas" (Ferguson, p. 2019, p. 294).
} 
única tarefa determinada, alienando-os das questões da comunidade, a ponto até de se esquecerem de que fazem parte dela. Ademais, a separação das profissões pode alcançar os departamentos da política e da guerra:

Cada departamento de Estado é objeto de uma profissão em separado; cada candidato a um cargo público deve passar por uma educação determinada e, tal como nos cursos universitários, obter uma proficiência correspondente ao posto a que aspira. Os graduados são instruídos em questões de Estado, militares ou de receita, bem como de literatura, e embora o aprendizado ofereça o caminho mais rápido ao privilégio, ele se resume, na verdade, na capacitação em ler e escrever, pois o grande objetivo do governo é consumir os frutos que ele mesmo semeou. Mas, apesar de todos esses recursos e das preparações destinadas à sua utilização, o Estado é fraco e, em meio a todos os sábios em matéria militar e política, e aos milhões que servem à profissão militar, não encontra um único indivíduo apto a enfrentar os perigos que ameaçam o país e erigir uma defesa contra as repetidas incursões de um inimigo com reputação de grosseiro e ignóbil (Ferguson, 2019, p. 313).

Nessa situação, soldados e homens públicos passam a ser meros funcionários que exercem suas atividades específicas sem qualquer consideração ao bem da nação. Além disso, em matéria militar, essa separação faz surgir exércitos permanentes, que pode acarretar um duplo problema: por um lado, os soldados podem não ser capazes de defender o país, exatamente porque são contratados meramente para realizar uma função, sem interesse direto pela preservação do Estado; por outro, os cidadãos, subtraídos da obrigação militar, não exercitarão as virtudes marciais importantes para a manutenção de uma nação.

Por fim, há ainda as consequências negativas para o espírito nacional decorrentes da expansão territorial, pois o alargamento pode fazer com que os membros de um corpo político percam “o senso de toda conexão" entre si (Ferguson, 2019, p. 304). Esse tema será discutido quando tratarmos da história da República romana.

No que diz respeito ao desperdício de recursos nacionais, Ferguson aborda duas questões principais, quais sejam, a riqueza e o endividamento públicos. $\mathrm{O}$ autor afirma, primeiramente, que "a riqueza do Estado é a soma da fortuna de seus membros" (Ferguson, 2019, p. 321). Ainda que uma máxima geral, essa afirmação precisa ser nuançada: é que nem sempre a fortuna privada se converte em riqueza pública, ou seja, é 
possível haver um Estado pobre cujos membros sejam ricos ${ }^{126}$. Isso porque, segundo o autor, a "arrecadação não é proporcional ao que se supõe ser redundante na propriedade privada", quer dizer, mesmo que "os súditos tenham propriedades suntuosas", o que eles julgam ser excedente e que não prejudicaria seus modos de vida, seus investimentos ou atividades comerciais podem estar muito aquém do que é exigido "para a realização dos propósitos nacionais”, causando sua “debilidade” (Ferguson, 2019, p. 321).

Um desses propósitos nacionais, talvez o principal, seja a defesa; especialmente nas nações comerciais modernas, nas quais, com a adoção de exércitos permanentes, o Estado deve manter os soldados, por vezes mesmo em tempos de paz. A necessidade de custear os exércitos, devido à separação da profissão do soldado e dos demais cidadãos, é, para Adam Smith, uma questão inerente ao avanço da sociedade, e, portanto, próprio da sociedade civilizada:

Quando a arte da guerra também se desenvolveu até se tornar uma ciência intrincada e complicada, quando o evento da guerra deixa de ser determinada, como nas primeiras épocas da sociedade, por uma única e irregular batalha ou escaramuça, mas quando a disputa é decidida por meio de muitas campanhas diferentes, cada qual durando a maior parte do ano; torna-se universalmente necessário que o público deva manter aqueles que o servem na guerra, ao menos enquanto estão empregados naquele serviço (Smith, 1981, vol. II, p. 695).

Se para Smith a manutenção de um exército permanente é uma questão universalmente necessária devido aos avanços da sociedade, para Ferguson, esse é um exemplo de desperdício de recursos nacionais ${ }^{127}$, já que “exércitos numerosos mantidos em casa ou no estrangeiro sem um objetivo nacional são tantas bocas desnecessárias que exaurem os suprimentos públicos, e tantas mãos que poderiam ser utilizadas nas artes

\footnotetext{
${ }^{126}$ Hume, no ensaio Do comércio, coloca a questão da seguinte forma: "Embora se possa supor que, em certos aspectos, a grandeza de um Estado e a felicidade de seus súditos sejam independentes, elas são inseparáveis no que diz respeito ao comércio: assim como homens privados recebem do poder público uma maior quantidade para a manutenção de seus negócios e de sua propriedade, assim também a comunidade se torna mais poderosa na mesma razão da opulência e da extensão do comércio de homens privados. Essa máxima é verdadeira em geral, mas não posso deixar de pensar que possivelmente admite exceções, e que muitas vezes a estabelecemos sem as devidas reservas e limitações. Pode haver circunstâncias em que o comércio, a riqueza e o luxo dos indivíduos, em vez de adicionar força à comunidade, sirvam apenas para enfraquecer seus exércitos e diminuir sua autoridade entre as nações vizinhas [...]", em: Hume, A arte de escrever ensaio. Tradução de Márcio Suzuki e Pedro Paulo Pimenta. São Paulo: Editora Iluminuras, 2008, pp. 196-197.

${ }^{127}$ No que diz respeito aos exércitos permanentes, Ferguson não foi crítico apenas por causa dos enormes gastos necessários à sua manutenção, mas principalmente porque sua adoção tem consequências morais e políticas para as nações. $\mathrm{O}$ autor defende mesmo o estabelecimento de milícias, como será discutido mais à frente, na seção sobre a defesa das nações comerciais modernas.
} 
lucrativas". Na verdade, esse desperdício pode ocasionar um problema ainda mais grave para uma nação, que é o endividamento público: para sustentar esses exércitos, "em alguns casos, Estados tentam disfarçar os riscos que correm expandindo o crédito em vez de empregar capital" (Ferguson, 2019, p. 322). Ferguson não discute de forma pormenorizada o problema da dívida pública, apenas diz que "um gasto realizado em casa ou no estrangeiro, com base em arrecadações dadas ou em antecipações futuras, se não trouxer retorno será por certo uma das causas da ruína nacional" (Ferguson, 2019, p. 323). Essa formulação é bastante próxima à de Hume, em seu ensaio Do crédito público (1752):

[...] nosso expediente moderno, o qual se tornou muito geral, é o de hipotecar as receitas públicas, e confiar que a posteridade pagará as incumbências contratadas pelos seus antecessores. Estes, tendo diante de seus olhos, tão bom exemplo de seus sábios pais, terão a mesma prudente confiança em sua posteridade; os quais, por fim, mais por necessidade que por escolha, serão obrigados a depositar a mesma confiança em uma nova posteridade (Hume, 1994, p. 350).

Ora, ainda que Ferguson exponha alguns problemas relacionados à riqueza das nações, tema que ocupou muitos de seus contemporâneos, em especial Hume e Smith, decerto esse não é seu objetivo principal no Ensaio. Ademais, se suas considerações sobre a virtude, seja ela individual ou nacional, não dizem respeito a fatores externos como a riqueza, tampouco suas considerações sobre a corrupção e o declínio dirão. É que "as maneiras são tão importantes quanto o número de homens e sua riqueza, e a corrupção delas deve ser considerada como a principal causa do declínio e da ruína de uma nação" (Ferguson, 2019, p. 327) ${ }^{128}$.

\section{III.iv. A história de Roma}

Segundo o próprio Ferguson, explicar o declínio das nações eminentes é uma tarefa difícil. Como foi exposto anteriormente, em teoria, são muitas as razões que podem levar uma nação à ruína e raramente elas ocorrem isoladamente. A história de cada uma contém fatores muito específicos que devem ser considerados. Ainda assim, foi a comparação que permitiu ao filósofo estabelecer essas regras gerais em matéria de

${ }^{128}$ Essa afirmação de Ferguson invalida a conclusão de Claude Gautier (2011) sobre a relação de causa e efeito entre declínio e corrupção. O comentador afirma que, para Ferguson, "a corrupção não é colocada como uma causa do declínio, mas como um efeito" (Gautier, 2011, p. 93, grifo do autor). 
política; ademais, a comparação continua relevante pois possibilita que façamos previsões futuras no que diz respeito à trajetória das nações comerciais modernas. Segundo Iain McDaniel (2013), para Ferguson ${ }^{129}$, "Roma não é um modelo para os Estados europeus modernos" (p. 15), mas ainda assim, sua história permite que a tomamos como exemplo do que pode suceder às nações polidas de modo geral, quando a própria grandeza parece engendrar um retorno à fraqueza:

O Império Romano, que por séculos não teve rivais, que submetera todas as nações as quais ousaram contestar o seu lugar e sem temer a concorrência de nenhuma outra potência, tombou por fim diante de um inimigo grosseiro (artless) e desprezível. Exposto em sua fronteira a invasões e pilhagens, e por fim à conquista, caiu primeiro nas extremidades, depois veio abaixo por todos os lados. Seu território foi desmembrado, e províncias inteiras apodreceram como uma árvore idosa cujos ramos não precisam ser arrancados com violência. A bravura com que Mário repelira os ataques de bárbaros em épocas pregressas, a força civil e militar que o cônsul e as legiões empregaram para estender o império, tudo isso desaparecera. A grandeza romana, fadada a afundar tal como emergira, foi lentamente ferida a cada embate. Viu-se então reduzida a suas dimensões originais, aos limites de uma única cidade; e dependendo, para sua preservação, da suspensão de um cerco, acabou extinguida de um só golpe: o ferrete que outrora havia espalhado suas brasas pelo mundo apagou-se tal como uma vela no soquete (Ferguson, 2019, pp. 290-291).

O exemplo de Roma é emblemático: foi uma República extremamente virtuosa e um Império de uma vastidão territorial sem precedentes, quando declinou e se viu "reduzida a suas dimensões originais", sendo posteriormente "extinta de um só golpe". Antes de Ferguson, Montesquieu, nas Considerações, tratou da história de Roma, estabelecendo relações causais entre seus diversos eventos a fim entender os motivos de sua grandeza e de sua decadência ${ }^{130}$.

Em primeiro lugar, é importante notar que, para Montesquieu, grandeza não é somente eminência, mas principalmente vastidão territorial ${ }^{131}$, e essa grandeza é vista

\footnotetext{
${ }^{129}$ No ensaio Da liberdade civil, Hume mostra igualmente que não se pode comparar as nações antigas e as nações modernas. Segundo ele, a máxima da antiguidade de que as artes e as ciências só poderiam surgir em nações livres não se aplica à modernidade, pois nos governos absolutos do período, em especial o francês, "que quase nunca gozou de liberdade duradoura", as artes e ciências alcançaram um grau de perfeição próximo a "qualquer outra nação" (Hume, 2011, p. 64).

${ }^{130}$ Uma análise mais exaustiva das Considerações de Montesquieu pode ser encontrada em Oake, R. Montesquieu's Analysis of Roman History. In.: Journal of the History of Ideas, Vol. 16, No. 1 (Jan., 1955), pp. 44-59.

${ }^{131}$ Em uma nota de seu Montesquieu and England, Gonthier afirma que há uma carta de Montesquieu a Lady Hervey em que o autor expressa sua intenção original de usar o termo "aggrandissement" (cujo sentido
} 
como resultado da República. A razão disso é que Roma teria estabelecido um sistema político muito virtuoso e adequado a seus propósitos, primeiramente dividindo as terras do Estado entre seus membros, o que garantia a igualdade necessária nesse tipo de governo e "criava também bons exércitos, pois cada qual tinha igual interesse, e muito grande, em defender sua pátria" (Montesquieu, 2002, p. 23). Dessa forma, não somente podiam contar com um grande número de soldados, mas com um exército muito vigoroso e eficiente, já que seus homens lutavam em causa própria. Esse arranjo tornou os romanos imbatíveis e fez seu território crescer gradualmente. Mas a grandeza de Roma não se deveu apenas à sua excelência bélica:

O governo de Roma teve o traço admirável de que, desde seu surgimento, tal foi sua constituição que, quer pelo espírito do povo, pela força do Senado ou pela autoridade de alguns magistrados, qualquer abuso de poder sempre pôde ser corrigido (Montesquieu, 2002, p. 68).

Quer dizer, o sistema constitucional de "checks and balances" dos romanos garantia a moderação do poder e, portanto, a liberdade de seus membros ${ }^{132}$. Assim, unindo poderio militar e sabedoria política, Roma engrandeceu e conquistou o universo (Montesquieu, 2002, p. 63), fomentando guerras entre inimigos, conferindo títulos de aliado a alguns povos conquistados e principalmente, dissolvendo alianças vizinhas para que cada cidade fosse independente entre si, mas dependente de Roma.

Era uma maneira lenta de conquistar: vencia-se um povo e se ficava satisfeito em enfraquecêlo; impunha-se-lhe condições que o minavam imperceptivelmente; quando ele se recuperava, era ainda mais enfraquecido e se tornava súdito, sem que se pudesse indicar a data precisa de sua sujeição. Assim Roma não era propriamente uma monarquia ou uma República, mas a cabeça do corpo formado por todos os povos do mundo (Montesquieu, 2002, p. 57).

Nesse cenário de grandeza pode parecer difícil conceber as razões que causariam a decadência de Roma. Montesquieu afirma que, "nos diferentes autores, só se ouve falar nas divisões que puseram Roma a perder. Mas não se percebe que essas divisões lhe eram

é mais próximo de crescimento, ainda que permita a acepção de "tornar-se mais importante") ao invés de "grandeur" (termo mais ambíguo e que significa tanto poderio moral e político quanto vasta dimensão) nos título das Considerações. Cf. Gonthier, U. Montesquieu and England. London: Pickering \& Chatto Limited, 2010, p. 194. Isso nos faz crer que Montesquieu quisesse se referir, em especial, à grandeza territorial, sobretudo quando se trata de atribuir à grandeza territorial a causa da decadência de Roma.

132 "Em uma palavra, um governo livre, isto é, sempre agitado, só pode manter-se quando é capaz, por suas próprias leis, de se corrigir" (Montesquieu, 2002, p. 69). 
necessárias, sempre o tinham sido e sempre o seriam" (Montesquieu, 2002, p. 74). Para Voltaire, por exemplo, "as divisões internas" dos romanos "teriam finalmente os tornados escravos" (Voltaire, 2007, p. 24). Na verdade, Montesquieu enfatiza que as divisões são próprias de um "Estado livre" e que "em regra, sempre que vemos toda a população tranquila em um Estado que dá a si mesmo o nome de República, podemos ter certeza de que nele não existe liberdade" (Montesquieu, 2002, p. 74, grifo do autor). Assim, o que pode destruir uma república não são as facções que as constituem naturalmente, mas outro aspecto que está em desacordo com essa forma de governo, qual seja, a grande extensão territorial.

Nessa época, Roma já não era a cidade cujo povo tivera apenas um mesmo espírito, um mesmo amor à liberdade, um mesmo ódio à tirania, e na qual a inveja do poder do Senado e das prerrogativas dos nobres, sempre mesclada de respeito, não passava do amor à igualdade. Transformados os povos da Itália em seus cidadãos, cada cidade levou para ela seu espírito, seus interesses particulares e sua dependência de um grande protetor. Dilacerada, a cidade deixou de formar um todo unido. Como só se era cidadão por uma espécie de ficção, e já não se tinha os mesmos magistrados, as mesmas muralhas, os mesmos deuses, os mesmos templos e as mesmas sepulturas, Roma já não era vista com os mesmos olhos. Não mais havia o mesmo amor à pátria. Os sentimentos romanos deixaram de existir (Montesquieu, 2002, p. 73).

Vemos, portanto, que a corrupção dos romanos se deu pela própria grandeza da República, pois, dessa forma, ela "deixou de formar um todo unido", e somente ela, segundo Montesquieu, "transformou em guerras civis os tumultos populares" (Montesquieu, 2002, p. 74). Ainda assim, precisamos indagar como exatamente a grandeza destruiu Roma.

$\mathrm{Na}$ teoria das formas de governo, tal como aparece no Espírito das leis, Montesquieu diz que há três espécies de regimes: o republicano, o monárquico e o despótico. Cada um deles tem sua natureza, princípio e leis próprias. O governo republicano, que está em questão aqui, tem como princípio a virtude; isso significa que seu motor é o amor pela república. Há ainda uma divisão da república em democracia e aristocracia, divisão que diz respeito à sua natureza, ou seja, a quem o poder soberano está atribuído: em uma democracia é "o povo em conjunto" (Montesquieu, 2005, p. 19) que o possui e na aristocracia esse poder "está nas mãos de um certo número de pessoas" (Montesquieu, 2005, p. 23). A República romana, ao menos em sua configuração inicial, tendia mais para uma democracia; portanto, seu princípio não era somente o amor pela 
república, mas também o amor pela igualdade e pela frugalidade (Montesquieu, 2005, p. 56). Dessa forma, podemos entender por que Montesquieu afirma ser sábia a divisão de terras feita inicialmente em Roma, pois com ela temos a igualdade. Com efeito, o que motivou a grandeza dos romanos foi uma constituição perfeitamente adequada ao seu tipo de governo, não só com a divisão das terras, mas também com a instauração do Senado, que funcionava como um mediador do poder do povo e evitava um espírito de igualdade extrema $^{133}$.

No entanto, há ainda uma outra característica fundamental da natureza das repúblicas, característica essa que Roma transgrediu tão logo se tornou grande:

É da natureza da república que ela só possua um pequeno território; sem isso não pode subsistir. Numa república grande, existem grandes fortunas e consequentemente pouca moderação nos espíritos; existem depósitos muito grandes para colocar entre as mãos de um cidadão; os interesses particularizam-se; um homem sente, primeiro, que pode ser feliz, grande, glorioso, sem sua pátria; e, logo, que pode ser o único grande sobre as ruínas de sua pátria (Montesquieu, 2005, p. 132).

A grandeza territorial mostra-se incompatível com uma república porque perverte o espírito de igualdade e de moderação do povo, mas mais ainda, porque corrompe sua virtude principal, que é o amor pela república ou um sentimento de que a pátria está em primeiro lugar, não as paixões individuais de seus membros.

Numa república grande, o bem comum é sacrificado em prol de mil considerações, está subordinado a exceções, depende de acidentes. Numa república pequena, o bem público é mais bem sentido, mais bem conhecido, mais próximo de cada cidadão; os abusos são menores e, consequentemente, menos protegidos (Montesquieu, 2005, p. 132).

Foi exatamente isso que ocorreu em Roma: a grandeza corrompeu o sentimento de bem público e tornou necessárias mudanças na constituição. Segundo Montesquieu, “é verdade que as leis de Roma se tornaram impotentes para governar a República. Mas uma coisa que sempre se viu é que boas leis, que fazem com que uma pequena República se engrandeça, tornam-se-lhe custosas quando ela cresce, por terem sido tais que seu efeito natural era criar um grande povo, e não governá-lo" (Montesquieu, 2002, p. 75). A

133 “O princípio da democracia corrompe-se não somente quando se perde o espírito de igualdade, mas também quando se adquire o espírito de igualdade extremo e cada um quer ser igual àqueles que escolheu para comandá-lo" (Montesquieu, 2005, p. 121) 
fim de governar o império, as novas leis já não mais tinham a capacidade de moderação ${ }^{134}$, pois enfraqueceu o magistrado, fortaleceu alguns poucos e por fim, tornou inútil "toda a sabedoria do Senado" (Montesquieu, 2002, p. 72).

Mas as mudanças ocasionadas pela grandeza de Roma não somente alcançaram a constituição, o próprio exército foi desvirtuado, quando se abriu uma "lacuna entre os exércitos nas províncias e o governo civil da república” (McDaniel, 2013, p. 143):

Quando a dominação de Roma se limitava à Itália, a República podia subsistir com facilidade. Todo soldado era também cidadão: cada cônsul recrutava um exército e outros cidadãos iam à guerra, sob o comando do sucessor. Não sendo excessivo o número de soldados, atentava-se para só aceitar na milícia pessoas que possuíssem riqueza suficiente para ter interesse na conservação da cidade. Por último, o Senado observava de perto a conduta dos generais e lhes tirava a ideia de fazer qualquer coisa contra seus deveres (Montesquieu, 2002, p. 71).

Os cidadãos, que outrora serviam como soldados aos propósitos de Roma, já não mais se identificavam com ela; depois, passou-se a aceitar mercenários para garantir um grande contingente; e por fim, lutando em províncias muito afastadas da própria cidade, esses homens "já não eram mais os soldados da República, e sim de Sila, de Mário, de Pompeu ou de César" (Montesquieu, 2002, p. 71). Foi assim que os generais das províncias adquiriram grande poderio e puderam, com suas legiões próprias, usurpar o governo civil de Roma através da força militar ${ }^{135}$ e sem que o Senado pudesse impedir. Montesquieu narra, a partir daí, a sucessão de governos do período imperial:

O que se chamava Império Romano durante esse século era uma espécie de República irregular, mais ou menos semelhante à aristocracia de Argel, onde a milícia, que detém o poder soberano, faz e desfaz magistrados aos quais se dá o título de dei. Talvez seja uma regra bastante geral que os governos militares, sob certos aspectos, são mais republicanos do que monárquicos (Montesquieu, 2002, p. 133).

\footnotetext{
134 “As leis de Roma tinham dividido sabiamente o poder público em um grande número de magistraturas, que apoiavam, continham e moderavam umas às outras; como todas tinham apenas um poder limitado, todos os cidadãos estavam aptos a chegar a elas, e o povo, vendo passar diante de si vários personagens, uma após outro, não se habituava a nenhum deles. Nessa ocasião, o sistema da República modificou-se: os mais poderosos fizeram com que o povo lhes desse encargos extraordinários, o que aniquilou a autoridade do povo e dos magistrados e pôs todas as grandes questões nas mãos de um só homem, ou de poucos" (Montesquieu, 2002, p. 83).

${ }^{135}$ Montesquieu afirma que Sila "entrou em Roma à mão armada e ensinou os generais romanos a violarem o asilo da liberdade" (Montesquieu, 2002, p. 82) e que César, como aquele, "queria chegar ao poder supremo de armas na mão" (Montesquieu, 2002, p. 84).
} 
Dessa forma, portanto, ocorreu a passagem para o Império ou para a República irregular, quer dizer, não livre. De acordo com Iain McDaniel (2013), "Montesquieu afirmara que os governos republicanos foram quase sempre incapazes de exercer o governo imperial tanto efetiva quanto responsavelmente" (p. 142). Com efeito, o autor trata esse período como a própria decadência da República, e aproxima seu governo militar ao despotismo. Segundo ele, no Espírito das leis, "o regulamento que os romanos criaram para aumentar o número de seus cidadãos tiveram efeito enquanto a república, no auge de sua instituição, só teve que reparar as perdas, produzidas por sua coragem, sua audácia, sua firmeza, seu amor à glória e por sua própria virtude. Mas logo as leis mais sábias não puderam restabelecer o que uma república agonizante, o que uma anarquia geral, o que um governo militar, o que um império duro, o que um despotismo soberbo, o que uma monarquia fraca, o que uma corte estúpida, idiota e supersticiosa tinham abatido sucessivamente [...]" (Montesquieu, 2005, 457).

Como dissemos, no Ensaio, Ferguson recorre à história de Roma para discutir a trajetória das nações polidas de modo geral, seu intuito, nesse texto, é mais analítico que narrativo. Anos mais tarde, em 1783, ele publica a História do progresso e ruína da República romana, onde de fato narra detalhadamente os fatos que se sucederam em Roma, desde sua fundação, até o início do Império. Em ambos os momentos, seus argumentos são muito semelhantes à avaliação que Montesquieu faz, nas Considerações, das causas da grandeza e da decadência de Roma ${ }^{136}$.

Tal como Montesquieu, Ferguson atribui à virtude das instituições políticas de Roma a eminência e a grandeza da República, e considera igualmente a grande extensão territorial decorrente como fator decisivo para sua decadência. Conforme se lê no Ensaio, toda a grandeza de Roma, erguida sob a égide da virtude, perdeu-se com o Império; assim, “admiramos o Império Romano como um modelo de grandeza e esplendor nacional, mas essa grandeza foi ruinosa para a virtude e a felicidade do gênero humano, e também, como se viu, incompatível com as consideráveis vantagens de que esse povo de conquistadores outrora desfrutara em matéria de governo e maneiras" (Ferguson, 2019, p. 100).

O autor não somente exalta as maneiras dos romanos, para quem "a comunidade era tudo" e as qualidades pessoais serviam de critério na distribuição dos serviços civis e

\footnotetext{
${ }^{136}$ Para os propósitos limitados desta tese no que concerne às considerações de Ferguson sobre a história de Roma, seguiremos sua argumentação no Ensaio. Para uma análise de sua História, ver McDaniel, I. Adam Ferguson in the Scottish Enlightenment. London: Harvard University Press, 2013.
} 
militares $^{137}$, como elogia sua constituição mista, pela moderação e previsibilidade no sistema de leis, dizendo que em tal "constituição favorável", "costumes conhecidos, a prática e as decisões das cortes, além dos estatutos positivos, adquirem autoridade de leis, e cada procedimento é conduzido por uma regra fixa e determinada. As melhores e mais efetivas precauções são tomadas, para haver uma aplicação imparcial de regras e casos particulares” (Ferguson, 2019, p. 237). Nesse sentido, o declínio de Roma é atribuído ao fato de que a corrupção das maneiras provocou uma mudança na constituição, consideração próxima à de Montesquieu, devido à extensão territorial da República:

À medida que o território se expande, suas partes perdem importância relativamente ao todo. Os habitantes não mais percebem uma conexão com o Estado, e é raro que se unam para executar um projeto nacional ou mesmo de uma facção. Longe dos assentos da administração, indiferentes à pessoa que disputa sua preferência, ensinam a maioria a se considerar como súditos de um soberano, não como membros de um corpo político. É notável que a expansão territorial, ao diminuir a importância do indivíduo para a comunidade e restringir sua capacidade de atuar junto a ele, tende a estreitar o escopo dos assuntos nacionais e a diminuir o número dos que são consultados em matérias de legislação e outras referentes ao governo (Ferguson, 2019, pp. 369-370).

Ferguson afirma que a perda do sentido de bem público, que era a virtude da República, foi determinante para a sua ruína, ou seja, que a causa do declínio foi a própria corrupção dos romanos. Mesmo que Montesquieu tenha discutido a corrupção do povo romano a partir da grandeza da República, afirmando que ela "deixou de formar um todo unido" (Montesquieu, 2002, p. 74) ou que, com a grandeza, passou-se a ser cidadão apenas "por uma espécie de ficção" (Montesquieu, 2002, p. 73), a ênfase de Ferguson no fato de que extensão territorial foi responsável pelo relaxamento do espírito nacional é uma marca distintiva da concepção moral do autor aplicada às questões políticas. Para ele, primeiramente houve a corrupção dos indivíduos, o que motivou, em seguida, uma série de eventos circunstanciais que foram responsáveis pelo declínio da República. Veremos como esses eventos se sucederam.

Em primeiro lugar, devido às inúmeras conquistas de um território cada vez maior, "criou-se intratáveis contradições entre as demandas dos governos militar e civil" (McDaniel, 2013, p. 143). É que, se por um lado, a constituição, elaborada para

\footnotetext{
137 "Para o grego ou para o romano antigo, o indivíduo não era nada, a comunidade era tudo. Para o moderno, em tantas nações da Europa, o indivíduo é tudo, e a comunidade não é nada. O Estado é uma mera combinação de departamentos em que a reputação, a riqueza e a eminência, ou o poder, são o prêmio de serviços prestados" (Ferguson, 2019, p. 96).
} 
administrar o território limitado da cidade, distribuía o poder de forma moderada e igualitária, por outro, "as desordens a que um grande império se expõe exigem precaução, vigilância e capacidade de reação. Províncias distantes devem ser mantidas sob força militar, e os poderes ditatoriais que os governos livres porventura convocam para esmagar insurreições ou se opor a outros males, parecem ser uma necessidade permanente, em domínios de certa extensão, para impedir a dissolução de um corpo cujas partes são reunidas e precisam ser cimentadas por medidas fortes, decisivas e sigilosas" (Ferguson, 2019, p. 370). Foi, por exemplo, com o intuito de expandir suas tropas que Mário autorizou o recrutamento de cidadãos romanos sem terras. Esses soldados guerreavam por recompensas, quer dizer, pela distribuição de terras feita pelo general, tornando-os ligados a seus líderes por interesse próprio, não pelos princípios da República. Essa corrupção que se deu nas próprias fileiras militares, fez com que se tornasse impossível, "mesmo para o general com maior espírito público", "tomar o controle do exército" (McDaniel, 2013, p. 144), sem o despotismo militar. Assim:

Poder-se-ia pensar que Roma não morreu de letargia, tampouco pereceu devido à remissão de seus ardores políticos domésticos. Seu destempero parece ter sido de natureza mais violenta e aguda. Contudo, se as virtudes de um Catão ou de um Bruto foram exercidas no momento em que a república perecia, a neutralidade e o cauteloso retiro de um Ático encontraram segurança nessa mesma estação tempestuosa, e o povo, como um grande corpo, manteve-se inabalado, alheio à torrente de uma tempestade que destruiu os homens de classes superiores. Na percepção do povo, o sentido de comunidade fora perdido, e mesmo as animosidades entre as facções haviam arrefecido; a comoção só dizia respeito aos que porventura fossem partidários de um líder ou soldados legionários. Não foi por falta de homens eminentes que a república caiu na obscuridade. Se olharmos para os nomes eminentes na história humana, poucas épocas oferecem uma lista tão numerosa. Mas esses nomes se destacaram em uma luta pelo poder, não no exercício de direitos iguais. O povo fora corrompido; um império tão vasto precisava de um senhor (Ferguson, 2019, p. 308, grifo nosso).

É importante notar que Ferguson vê como natural a filiação dos homens a um partido: "nossa fidelidade a uma divisão ou seita muitas vezes deriva, ao que parece, de uma animosidade concebida em relação à posição oposta, e que, por sua vez, surge de um zelo pelo lado que adotamos e do desejo de defender os direitos de nosso partido" (Ferguson, 2019, p. 46). Como Montesquieu, Ferguson tem uma visão positiva acerca das divisões partidárias em uma república, para ele, as animosidades entre as diversas ordens 
de homens podem resultar em liberdade, se bem administradas pela constituição, pois elas são símbolos de zelo e espírito nacional. É dessa forma que, em segundo lugar, as facções da República só vieram a causar problemas quando a própria República já havia se deteriorado $^{138}$. Nas Reflexões anteriores ao estabelecimento de uma milícia, Ferguson comenta como, em Roma, em "tempo de corrupção", quando "as ideias de uma constituição, de liberdade e de independência" cessaram de "operar na mente do povo", "ligações pessoais" os dividiram, dando azo à ascensão de César e de Pompeu. Assim, não é porque os homens estavam divididos em partidos que a licenciosidade tomou conta da República, mas porque o povo se tornou "acessório à ambição de homens particulares" (Ferguson, 1756, p. 26).

Por fim, o surgimento de líderes populares, cumulados de poderes militares adquiridos nas províncias do Império, acabou pondo em perigo o próprio governo civil da República. A junção de poderes civil e militar de um César acabou gerando o governo militar. Com essa total corrupção, veio o governo despótico.

As regras do despotismo são feitas para governar homens corrompidos. Foram adotadas, em algumas ocasiões, mesmo pela república romana, e o machado ensanguentado, que aterroriza o cidadão criminoso e detém irrupções de vício casuais e temporárias, foi repetidas vezes entregue à vontade arbitrária do ditador. Terminaram por se estabelecer sobre as ruínas da própria república, quando o povo se tornara corrompido demais para ser livre ou o magistrado, na mesma situação, se recusava a abrir mão de seu poder ditatorial. Essa espécie de governo é resultado natural de uma corrupção contínua e crescente, mas, sem dúvida, em alguns casos veio antes, sacrificando vestígios de virtude que mereciam uma sorte melhor ao ciúme dos tiranos, ansiosos por aumentar seu poder. Em tais casos, esse método de governo introjeta aquela mesma corrupção cujos efeitos externos visava remediar. Quando o medo é a única motivação ao dever, os corações se tornam rapaces e vis. E esse medicamento, se aplicado a um corpo saudável, certamente irá produzir o mesmo destempero, que, em outros casos, estaria destinado a curar (Ferguson, 2019, pp. 330-331).

\footnotetext{
138 “As pretensões de uma ordem em particular terminam em tirania, quando não são contidas por um poder colateral; as de um príncipe se resolvem em despotismo; as da nobreza e dos sacerdotes redundam em abusos de aristocracia; as da plebe se dissolvem em confusão e anarquia. Mas esses desfechos não são óbvios, e não costumam ser objeto dos partidos; mas o fato é que as medidas propostas por um partido, uma vez adotadas podem gradualmente levar a extremos" (Ferguson, 2019, pp. 188-189).
} 


\section{III.v. Nações Comerciais Modernas}

Como dissemos, quando Ferguson recorre à história de Roma, não é para tornála um modelo para as nações comerciais modernas: é somente porque uma teoria política formulada sob bases empíricas precisa de dados factuais para refletir os seus princípios. Logo, como os Estados europeus ainda estão em sua trajetória de progresso, fazer previsão sobre seu declínio só pode ser possível através da mediação dos acontecimentos passados de outras nações que alcançaram, senão seu grau de grandeza e eminência, ao menos o mesmo estágio de desenvolvimento, ou seja, o estágio polido.

Em particular, Roma no auge de sua grandeza e Grã-Bretanha na modernidade, além de compartilharem o mesmo estágio de progresso, compartilham igualmente outras similaridades: uma dessas semelhanças é que ambas estabeleceram, como forma de governo, uma constituição mista; aquela "inclinando-se para a democracia", esta "para a monarquia", e assim se "mostraram as grande legisladoras dentre as nações. A primeira legou ao continente europeu a fundação e grande parte da superestrutura do código civil, a outra, uma ilha, levou a autoridade e o governo da lei a um ponto da perfeição nunca antes visto na história humana" (Ferguson, 2019, p. 237). Dessa forma, uma e outra desenvolveram as artes políticas a tal ponto de criarem instituições muito sábias; no entanto, a tendência da Inglaterra para a monarquia é uma diferença relevante para o filósofo político, pois esse sistema de governo guarda especificidades próprias muito diferentes do da república. Ademais, uma dessemelhança fundamental para a filosofia de Ferguson é que "os romanos se tornaram ricos perseguindo suas conquistas" enquanto "algumas nações modernas chegam ao domínio e à expansão com base em máximas de comércio" (Ferguson, 2019, p. 199). Ora, o progresso das artes lucrativas nas nações modernas pode dar origem a ameaças estranhas às suas considerações sobre a grandeza $\mathrm{e}$ o declínio de Roma ${ }^{139}$.

\section{III.v.1. Separação das artes e das profissões}

Umas das principais particularidades das nações modernas é "o progresso do comércio", que, segundo Ferguson, "se resume à contínua subdivisão das artes

\footnotetext{
${ }^{139}$ Ferguson não descarta a expansão imperial moderna como uma possível ameaça, tal como ocorreu em Roma, à estabilidade dos Estados europeus. No entanto, entendemos que essa é uma consideração apenas lateral no seu pensamento político, ainda que seja central para Montesquieu, como expresso em Réflexions sur la monarchie universelle en Europe.
} 
mecânicas" (Ferguson, 2019, p. 256). No Ensaio, há uma seção específica sobre a separação das artes e das profissões, onde lemos:

É evidente que, embora incitado pelo senso de necessidade ou pelo desejo de conveniência, e estimulado por vantagens de localização ou de política, um povo não pode realizar grandes progressos no cultivo das artes da vida até que tenha separado e atribuído a diferentes pessoas as diversas tarefas que demandam peculiar destreza e atenção. O selvagem ou o bárbaro têm de construir e de plantar, e de fabricar por si mesmos, e preferem, no intervalo entre as emergências e fatigas, o desfrute da preguiça ao crescimento de sua fortuna. Provavelmente sentem-se desestimulados, dada a gama de suas necessidades, na dedicação à indústria, ou então sua atenção, dividida entre diferentes tarefas, os impede de adquirir habilidade para a administração de um objeto em particular (Ferguson, 2019, p. 255).

Assim, Ferguson atribui às nações avançadas a possibilidade de "realizar grandes progressos no cultivo das artes da vida". No progresso da sociedade é "o desfrute da paz e a perspectiva de poder trocar uma mercadoria por outra transformam gradualmente o caçador e o guerreiro em comerciante e mercador" (Ferguson, 2019, p. 255). No entanto, essa possibilidade é dada pela própria natureza humana ${ }^{140}$, por um princípio de progressão ou ambição que leva os homens a aperfeiçoarem, de modo ilimitado, as artes que praticam. Sem detalhar, Ferguson diferencia a separação das profissões de modo geral na sociedade da separação de cada atividade para fins de produção, a separação das artes ${ }^{141}$.

$\mathrm{O}$ artista constata que, quanto mais sua atenção se restringe a uma parte de seu trabalho, suas produções se tornam mais perfeitas e a quantidade delas aumenta em suas mãos. Qualquer um que se dedique à manufatura pode constatar que, quanto mais subdivide as tarefas de seus trabalhadores e mais braços emprega em artigos separados, mais as suas despesas diminuem e os seus lucros aumentam (Ferguson, 2019, p. 256).

Smith abre A Riqueza das Nações, publicada em $1776^{142}$, com um capítulo sobre a divisão do trabalho; ali ele especifica as causas do aumento produtivo do trabalho com

\footnotetext{
140 Smith atribui a tendência a separar as tarefas à natureza humana, a "uma propensão à troca, ao intercâmbio e à transação (propensity to truck, barter, and exchange)" (Smith, 1981, p. 25).

${ }^{141}$ Essa nomenclatura do autor contempla dois aspectos da divisão do trabalho tal como pensada por Marx: a divisão do trabalho na produção manufatureira e a divisão na sociedade, com diversas profissões.

${ }^{142}$ Embora A Riqueza das Nações tenha sido publicada depois do Ensaio, algumas conclusões sobre a divisão do trabalho já haviam aparecido em escritos anteriores de Adam Smith, principalmente em suas lições (Lectures on Jurisprudence) da década de 60 e que serviram de esboço para A Riqueza. Conforme
} 
a separação das tarefas. Tomando como exemplo a manufatura de alfinetes, que pode ser "dividida em dezoito operações distintas" ${ }^{143}$, o autor compara a capacidade produtiva (em termos quantitativos) do emprego de diversas pessoas na execução de uma ou duas dessas operações com o trabalho de um único homem que realizasse todas as tarefas sozinho. O resultado é impressionante: dez homens produzem juntos até 48000 alfinetes por dia (ou seja, até 4800 cada um), quando dividem seu trabalho, ao passo que um homem executando sozinho todas as funções, não produziria mais que 20 (Smith, 1981, p. 15).

O mecanismo da divisão do trabalho, tal como ilustrado no exemplo da produção do alfinete, é um tema central na Riqueza e, no entender de Smith, uma das principais características das sociedades ditas “civilizadas”. É graças a ele que se alcançou na modernidade uma produtividade tão distintiva, tornando possível uma "opulência universal" 144 e a separação da população em "classes produtivas e não produtivas"145. Dessa perspectiva, para Smith, o progresso do comércio e das artes traz ganhos sociais claros, inclusive para os mais pobres, principalmente no que diz respeito aos ganhos em termos de riqueza. Ele diz, por exemplo, que "é a grande multiplicação das produções de todas as diferentes artes, em consequência da divisão do trabalho, que ocasiona, numa sociedade bem governada, aquela opulência universal que se estende até os estratos sociais mais baixos" (Smith, 1981, p. 22); e, ainda, que "de fato, quando comparado com o luxo mais extravagante de um superior, sua acomodação [dos trabalhadores] parece, sem dúvida, extremamente simples e fácil; e, igualmente, parece ser verdade que, talvez, a acomodação de um príncipe europeu nem sempre exceda tanto aquela de um camponês industrioso e frugal quanto a acomodação deste último excede aquela de muitos reis africanos, senhores absolutos das vidas e das liberdades de dez mil selvagens nus" (Smith, 1981, pp. 23-24).

uma nota de Ferguson, no Ensaio (2019, p. 210), ele conhecia essas lições e sabia também do projeto de publicação da Riqueza das Nações; no entanto, não é claro qual a real influência de Smith sobre Ferguson no que diz respeito a esse assunto. Para uma discussão mais detalhada sobre o tema, vide Hamowy, R. The Political Sociology of Freedom: Adam Ferguson and F. A. Hayek. Cheltenham: Edward Elgar, 2005.

${ }^{143} \mathrm{O}$ exemplo do alfinete não é fortuito. Ele já aparecera na Encyclopédie de Diderot e D'Alembert em 1751. No verbete épingle são descritas as 18 operações separadas na fabricação do alfinete.

${ }^{144}$ Christopher Berry, em The ideia of Commercial Society in the Scottish Enlightenment, mostra como para Smith a divisão do trabalho universalizou a distribuição de riquezas nas nações comerciais, as quais, “comparadas aos 'estágios' anteriores, é mais rica no sentido crucial de que seus habitantes são melhor alimentados, vestidos e abrigados" (Berry, 2013, p. 66).

145 Segundo Istvan Hont (1983), para Smith, nas nações selvagens, "'todo indivíduo capaz de trabalhar era mais ou menos empregado em trabalho útil' e esforçava-se para prover tanto sua família quanto aqueles incapazes de trabalhar"; enquanto que nas sociedades comerciais modernas, o "assalariado pobre [...] suporta toda a estrutura da sociedade e provém os meios de conveniência e conforto para todos os demais"” (p. 3). 
Não obstante isso, o autor não é insensível às consequências negativas da divisão do trabalho. Smith afirma que um trabalhador pode ser um exímio fabricante de alfinetes, chegando a produzir quantidades exorbitantes, mas é torpe, "incapaz de tomar parte em uma conversação racional", de "formar qualquer julgamento justo a respeito de até mesmo muitas das funções ordinárias da vida privada" e "é igualmente incapaz de defender seu país na guerra" (Smith, 1981, p. 782). Para remediar esse problema, Smith propõe que o Estado subvencione a educação dos mais pobres, para que possam, antes de começarem a se dedicar aos trabalhos "simples e uniformes", exercitar tanto seu entendimento quanto seu espírito marcial.

Ora, Ferguson não ignora os efeitos positivos da separação das artes e das profissões para o aumento da produtividade e para a qualidade das mercadorias. Nos Princípios, há uma passagem muito semelhante à de Smith sobre a divisão na manufatura do alfinete:

Entre as circunstâncias, portanto, que foram anteriormente mencionadas, relacionadas ao progresso das artes comerciais, nenhuma resulta de maneira mais óbvia para seu avanço que a separação das ocupações e a subdivisão de cada uma em um número conveniente de ramificações diferentes. Isso diminui a dificuldade de todo aprendizado e aumenta muito o produto de qualquer número dado de mãos. Uma variedade de pessoas, cada qual desempenhando não mais que uma parte na manufatura de um alfinete, pode produzir muito mais num dado período de tempo, do que, talvez, o dobro do número, se cada qual trabalhasse na produção como um todo ou desempenhasse todas as partes da construção daquele artigo diminuto" (Ferguson, 1792, vol. II, p. 424)

De modo geral, o autor reconhece também que a separação das artes e das profissões contribui para o enriquecimento das nações, pois, dessa forma, "as fontes de riqueza são escancaradas, materiais de toda espécie são trabalhados até o máximo da perfeição, e cada mercadoria é produzida em abundância.” (Ferguson, 2019, pp. 256257). Porém, Ferguson, no Ensaio, dedica-se mais propriamente a avaliar os efeitos negativos que decorrem dessas divisões ${ }^{146}$, inicialmente no que diz respeito à corrupção

\footnotetext{
${ }^{146}$ Pode ser por esse motivo que Karl Marx reclama a anterioridade de Adam Ferguson em relação a Adam Smith na discussão sobre a divisão do trabalho. Primeiro, em A miséria da filosofia (1847), numa rápida menção à cronologia da abordagem das "consequências penosas da divisão do trabalho"; depois, numa nota do capítulo $O$ dinheiro ou a circulação de mercadorias, livro I, de $O$ Capital (1867). No entanto, se considerarmos apenas as datas de publicação do Ensaio (1767) e da Riqueza das nações (1776), a despeito do fato de Adam Smith já ter abordado o tema anteriormente em suas lições, há sim uma precedência.
} 
dos indivíduos e, posteriormente, de forma mais geral, como podem ameaçar a boa fortuna nacional.

Em primeiro lugar, a divisão das tarefas na manufatura, como no exemplo da fábrica de alfinetes, cria uma infinidade de pequenas atividades que são, como afirma Smith, "simples e uniformes" (Smith, 1981, p. 785). Cada um desses trabalhos, embora conjuntamente contribuam para eficiência produtiva, "não requerem qualquer capacidade"; com efeito, diz Ferguson, "têm mais êxito quando o sentimento e a razão são suprimidos; a ignorância é a mãe da indústria, assim como da superstição. Reflexão e fantasia estão sujeitas a erro, mas o hábito de mover as mãos ou os pés independe de ambas. Por isso, as manufaturas prosperam mais quando a mente é menos consultada, e o ateliê pode ser considerado uma máquina (engine) cujas partes são os homens" (Ferguson, 2019, p. 258). Quer dizer, com a divisão do trabalho, são atribuídas aos trabalhadores da manufatura funções que não despertam sua imaginação nem sua razão, tampouco exercitam seus talentos, são trabalhos sórdidos e repetitivos que podem ser comparados àqueles realizados por uma máquina. Dessa forma, esses trabalhadores estão confinados a uma única atividade particular, sem qualquer relação com a totalidade do processo produtivo.

Em segundo lugar, a separação das profissões cria um novo modo de subordinação: "há um grau de subordinação que decorre da diferença entre talentos e disposições naturais, um segundo, consequente à repartição desigual da propriedade, e um terceiro, não menos sensível, que deriva dos hábitos adquiridos pela prática das diferentes artes" (Ferguson, 2019, pp. 259-260). Ora, a diferença entre as atividades que "não requerem habilidades ou tendem a contrair e limitar as perspectivas do espírito" e aquelas "levam a reflexões gerais que alargam o pensamento" (Ferguson, 2019, p. 258) dá origem a duas ordens de homens: as "ordens superiores" (superior orders) e as ordens inferiores ou de trabalhadores indigentes (Ensaio, 2019, p. 262). Portanto, a causa do surgimento dessas duas classes é mais propriamente a separação das artes e das profissões, e não uma grande diferença natural nos talentos dos homens ${ }^{147}$.

Como vimos, as classes inferiores estão submetidas a trabalhos sórdidos, que acarretam hábitos viciosos e corruptos:

\footnotetext{
${ }^{147}$ Em Adam Smith, temos o mesmo raciocínio: “A diferença de talentos naturais em diferentes homens é, na realidade, muito menor do que temos ciência; e as muitas capacidades diferentes que aparentam distinguir os homens de diferentes profissões, quando atingem a maturidade, não é, em muitas ocasiões, bem a causa, mas o efeito da divisão do trabalho" (Smith, 1981, p. 28).
} 
Em todo Estado comercial, apesar de pretensões a direitos iguais, a condição exaltada de uns poucos inevitavelmente prejudica muitos. Estamos acostumados a pensar que, num arranjo como esse, a extrema vileza de algumas classes viria principalmente da falta de conhecimentos e de educação liberal, e projetamos nelas a imagem do que teria sido nossa espécie em seu estado rude e inculto. Mas esquecemo-nos assim das muitas circunstâncias que, em especial em cidades densamente povoadas, tendem a corromper as ordens inferiores de homens. A ignorância é a menor de suas máculas. A admiração pela riqueza alheia engendra inveja e servidão; o hábito de agir sempre com vistas ao lucro leva à submissão; e, para satisfazer a avareza e a lascívia, praticam-se os mais variados crimes. Nada disso é exemplo de ignorância, mas de corrupção e vilania. O selvagem não recebeu a mesma instrução que nós e ignora nossos vícios; não reconhece nenhum superior e não se porta como servo; não sabe de distinções de fortuna e não tem como sentir inveja; mobiliza seus talentos para atuar nas causas mais nobres da sociedade humana como conselheiro ou soldado; e, na formação de seus sentimentos, conhece tudo o que o coração exige que se conheça, sabe identificar o amigo de quem gosta e o interesse público que desperta seu zelo (Ferguson, 2019, pp. 262-263).

Nessa passagem, fica claro que Ferguson faz uso de uma linguagem moral para se referir aos homens das ordens inferiores; ele utiliza, por exemplo, termos como baixeza, ignorância, infâmia e devassidão. Mas sua corrupção não é causada apenas pelo tipo de trabalho que realizam, é também agravada pelo desejo de riquezas; nas palavras de Ferguson: "o pobre, para escapar do estado medíocre em que se encontra, força cada nervo para se tornar rico" (Ferguson, 1791, vol. I, p. 244-245). O autor, diferentemente de Smith, não considera que a opulência moderna tenha tido consequências positivas para as classes inferiores, estendendo-se aos pobres; suas observações sobre o enriquecimento restringem-se às classes superiores. $\mathrm{Na}$ verdade, a concentração de riquezas destes homens é mais um fator de corrupção moral daqueles, pois gera inveja, cobiça, dentre outras paixões nefastas.

Se as classes inferiores são, dessa forma, corrompidas, podemos supor que as classes superiores, que praticam atividades menos degradantes e que desfrutam do conforto e da riqueza, estariam a salvos da corrupção.

Buscamos por sentimentos nobres e por uma mente aberta nas ordens de cidadãos que, por sua condição e fortuna, estão isentos de cuidados e atenções sórdidas. Tal é a descrição do homem livre espartano, e se a sorte do escravo antigo era mais miserável que a do indigente trabalhador e artesão moderno, é de se duvidar que as ordens superiores, que são respeitadas e têm posses, não estariam, proporcionalmente, abaixo da 
dignidade esperável de sua condição. Se as pretensões à justiça equânime e à liberdade terminarem por tornar todas as classes igualmente servis e mercenárias, teremos uma nação de hilotas, sem cidadãos livres (Ferguson, 2019, p. 262).

É interessante notar que, em sentido oposto do que se poderia esperar, quando se trata das classes superiores, não encontramos termos mais elevados ${ }^{148}$. Homens cujas profissões requerem mais conhecimentos e estudo, homens de negócio, os inventores e mestres, apesar de aplicarem seus talentos e exercitarem parte das disposições que a natureza lhes conferiu, estão sujeitos aos efeitos negativos da separação das artes e das profissões. Se eles não são corrompidos por causa do caráter abjeto de sua função, ainda assim realizam atividades muito particulares e descoladas de qualquer sentido de totalidade. A totalidade almejada por Ferguson é a do cidadão que, longe do trabalho ordinário, dedica-se à coisa pública. Em Esparta, por exemplo, ou mesmo entre os cidadãos romanos, a prática de todas as artes relacionadas à sobrevivência era destinada aos escravos ou às mulheres, cabendo, assim, à elite apenas as preocupações políticas e militares. Nas nações comerciais modernas, os homens das classes superiores, ao contrário, dedicam-se às atividades comerciais, e se preocupam sobretudo com o enriquecimento $^{149}$.

Portanto, podemos ter um cenário em que "corpos inteiros podem às vezes ser infectados por uma fraqueza epidêmica da cabeça ou por uma corrupção do coração que os desqualifica para as posições que ocupa" (Ferguson, 2019, p. 328). Enquanto os homens das ordens inferiores das nações comerciais modernas, os trabalhadores da manufatura, podem ser comparados aos escravos da antiguidade, os homens das ordens superiores não são semelhantes aos homens livres de outrora. Ou seja, com a divisão das artes e das profissões, não há a elevação de uma classe à custa de outra; estão todos, de alguma forma, corrompidos. Ainda que Ferguson reconheça que conforme a sociedade avança seja natural uma divisão como essa, ele não se furta a discutir seus efeitos perversos para as nações polidas em geral. Considerando as diferentes formas de governo,

\footnotetext{
148 Smith reconhece, mais imediatamente, apenas a sordidez que a divisão do trabalho pode gerar para os mais pobres: "no progresso da divisão do trabalho, o emprego da maior parte daqueles que vivem do trabalho, ou seja, a grande maioria do povo acaba por estar confinada a operações muito simples, frequentemente a uma ou duas. Porém, o entendimento da maior parte dos homens é necessariamente formado por suas ocupações ordinárias. O homem cuja vida é completamente dedicada a desempenhar operações muito simples, e cujos efeitos são, talvez, sempre os mesmos, ou quase os mesmos, não tem qualquer ocasião para empregar seu entendimento, ou exercitar sua invenção na procura de expedientes para remover dificuldades que nunca ocorrem. Ele perde, portanto, o hábito de tal uso, e geralmente se torna tão estúpido e ignorante quanto é possível se tornar uma criatura humana" (Smith, 1981, p. 782).

${ }^{149}$ A forma como o enriquecimento subverte a preocupação com a felicidade da nação será abordada na próxima seção, sobre o luxo.
} 
a corrupção das classes inferiores se tornará um problema maior para as democracias, pois pode desestabilizar o próprio funcionamento do sistema político, uma vez que "homens de disposição sórdida, dedicados a ocupações tacanhas, quando participam de assembleias populares, por mais que tenham sido escolhidos, são pessoas inadequadas para comandar" (Ferguson, 2019, p. 263). Nas monarquias e monarquias mistas, como a França e a Inglaterra respectivamente, ao contrário, é a corrupção das classes superiores ${ }^{150}$ que se torna um problema, na medida em que ameaça o poder intermediário que essas classes exercessem, como veremos a seguir.

\section{III.v.2. O luxo}

Da separação das artes e das profissões decorrem o comércio e a prosperidade das nações e, com eles, "o complexo aparato que os homens concebem com vistas a uma vida confortável e tranquila" (Ferguson, 2019, p. 335). A esse incremento nos confortos da vida, podemos chamar luxo. Porém, Ferguson adverte que o termo não é inequívoco e precisa ser definido com mais precisão:

Estamos longe de concordar na aplicação do termo luxo ou de saber em que medida seu sentido é consistente com a prosperidade de uma nação e a retidão moral da natureza humana. Às vezes, a palavra luxo é empregada para significar o modo de vida que nos parece necessário à civilização e mesmo à felicidade. Em nosso panegírico de épocas polidas, luxo é o mecenas das artes, o patrono do comércio, o propulsor da grandeza e da opulência nacional. Em nossa censura de maneiras degeneradas, é a fonte da corrupção e o presságio do declínio e da ruína da nação. É admirado ou desprezado; deve-se louvá-lo como ornamental e útil, ou proscrevê-lo como um vício (Ferguson, 2019, p. 335).

Assim, há, por um lado, aqueles que celebram o luxo e o consideram como uma simples “decorrência natural da arte e do comércio" (Ferguson, 2019, p. 336) e, por outro, aqueles que o censuram por julgá-lo um vício ou uma insígnia de devassidão moral.

\footnotetext{
${ }^{150}$ Para Ferguson, os homens das classes superiores, pela própria atividade que praticam, longe das determinações mais imediatas dos trabalhos sórdidos, são alçados a uma posição próxima à nobreza, devendo participar, juntamente com ela, das questões do Estado: "Profissões que requerem mais conhecimento e estudo, que mobilizam a fantasia e pressupõem o amor pela perfeição, que produzem o aplauso ou o lucro, põem o artista em uma classe superior e o aproxima de uma posição mais nobre, pois não está comprometido com nenhuma tarefa, segue apenas a disposição de sua mente e desempenha na sociedade um papel a que é levado pelos sentimentos do coração ou convocado pelo poder público" (Ferguson, 2019, pp. 260-261).
} 
Porém, de acordo com Ferguson, é preciso definir melhor o termo. Primeiro, ele não deve ser tomado como sinônimo de supérfluo ou um mero refinamento das necessidades básicas:

Mas, não importa qual o estágio do progresso das artes, mesmo que freássemos o seu avanço continuaríamos a ser acusados de luxuriosos por aqueles que não foram tão longe como nós. Em Esparta, o construtor e o carpinteiro estavam restritos ao uso do machado e do serrote; mas um casebre espartano passaria na Trácia por um palácio. E se a disputa diz respeito ao que é materialmente necessário à preservação da vida humana como padrão do que é moralmente lícito, então, como as faculdades físicas discordam das morais, e a propósito de um mesmo objeto, cada um teria de encontrar por si mesmo a regra mais conveniente. No mais das vezes, o casuísta toma a prática de sua condição e época como padrão do gênero humano. Se numa dada época ou condição ele condena o uso do coche, em outra ele condenaria o uso de calçados: a mesma pessoa que clama contra o primeiro provavelmente não teria poupado o segundo, se não se tratasse de um item herdado de épocas anteriores. Um censor do luxo nascido num casebre e acostumado a dormir sobre o feno jamais proporia que os homens retornassem às florestas e às cavernas em busca de abrigo, mas reconhece que é razoável e útil tudo o que já conhece, e só vê excesso e corrupção nos refinamentos mais recentes, de última geração (Ferguson, 2019, p. 336-337).

Ora, essa passagem guarda, aparentemente, muitas semelhanças com a discussão que Hume faz no ensaio Do refinamento nas artes, e não devemos esquecer que um primeiro esboço do Ensaio enviado a Hume por Ferguson tinha, ao que parece, o nome de "Ensaio sobre o refinamento" ${ }^{151}$. Distanciando-se das posições antagônicas assumidas pelos escritores que desde o século anterior vinham se envolvendo na chamada "querela do luxo"152, Hume observa logo na abertura de seu texto que "luxo é uma palavra de

\footnotetext{
${ }^{151}$ Em carta a Hugh Blair, Hume menciona que lera "uma pequena amostra" do Ensaio há alguns anos, em possível referência ao "Ensaio sobre o refinamento". Ainda que tenha gostado do esboço em questão, o texto pronto, o Ensaio sobre a história da sociedade civil, causou-lhe tanto desgosto que chegou a recomendar que se retardasse ou evitasse sua publicação. Segundo Hume: "Examinei os papeis de Ferguson mais de uma vez, os quais me foram entregues, há algum tempo atrás, por desejo dele. Sentei para lê-los com muita predisposição, fundada na minha boa opinião sobre ele, numa pequena amostra do que li há alguns anos e na sua estima e do Dr. Robertson por eles: mas eles, sinto muito em dizer, de forma alguma corresponderam à minha expectativa. Eu não os considero convenientes para ser dados ao público, por conta do estilo e do raciocínio; da forma e do assunto... É desnecessário entrar em detalhes, onde quase tudo me parece reprovável. Se eu retornar à Escócia no próximo verão, devo contribuir de qualquer modo para evitar ou retardar a publicação; porém, eles já foram colocados nas mãos do General Clerk e do Lorde Shelburne, que não são os melhores juízes do mundo; e se você não intervier, eles certamente serão publicados. Ficarei agradavelmente desapontado, caso o sucesso prove o contrário à minha opinião" (Hume, 1968, p. 11-12).

${ }^{152}$ Cf. Monzani, 1995.
} 
significação incerta e pode ser tomada tanto num bom quanto num mau sentido" (Hume, 2011, p. 209). Na verdade, o autor se esforça para desvincular, na natureza humana, o luxo do vício ${ }^{153}$, notando que o luxo individual pode ou não ser inofensivo, dependendo de como é cultivado, e, sobretudo, destacando as consequências positivas que seu efeito, o refinamento, têm para as sociedades humanas de maneira geral, na medida em que promovem a atividade e mantêm os homens à disposição do Estado tanto para produzir riquezas quanto para formar exércitos (condição esta sem a qual uma comunidade política não poderia subsistir - é um postulado compartilhado, em certa medida, por Hume, Smith e Ferguson).

Para Ferguson não se pode censurar o luxo porque ele parece extrapolar aquilo que supomos ser necessário à preservação da vida, pois mesmo "o termo necessidades da vida é vago e relativo" (Ferguson, 2019, p. 207, grifo do autor). Como vimos no capítulo anterior, o autor não considera que haja uma hierarquia das necessidades dos homens, quer dizer, que artigos básicos e de mera sobrevivência, como comida e moradia, sejam prioritários ou mais urgentes que outras necessidades como ornamento e decoração. Dessa forma, supõe-se erroneamente que os selvagens, no estágio mais rude da existência humana, não praticariam artes, a não ser aquelas muito rudimentares cuja finalidade é a de obter e preparar a comida e construir instrumentos grosseiros para sua preservação. Na filosofia de Ferguson, a arte é natural ao homem ${ }^{154}$ e está presente em todos os estágios da sociedade, não apenas no mais avançado. O luxo, como resultado da prática das artes é, portanto, uma decorrência natural e própria da atividade humana. Como afirma Luiz Roberto Monzani (1995), Ferguson "insere, encapsula o artifício nas malhas da estrutura da natureza humana e, assim fazendo, faz com que o problema se dissolva. É inútil fazer a apologia ou a condenação do luxo: trata-se de um dado da natureza humana sobre o qual qualquer discurso, laudatório ou não, é vão" (p. 53).

Ademais, repreender o luxo por considerá-lo responsável pela corrupção moral é não compreender que a virtude é uma característica da mente e que independe dos

\footnotetext{
${ }^{153}$ Hume diz que as "gratificações sensuais" só "são vícios se obtidas à custa de alguma virtude, como liberalidade ou caridade; também são loucura, se por causa delas o homem arruína sua fortuna, condenandose a penúria e mendicância" (Hume, 2011, p. 209).

154 “É comum referirmo-nos à arte por contraposição à natureza; mas a arte pertence à natureza humana. $\mathrm{O}$ homem é, em certa medida, o artífice de sua própria estrutura (frame), bem como de sua fortuna, e está destinado, desde a mais tenra idade, a inventar e criar. Aplica os mesmos talentos a uma variedade de propósitos e desempenha o mesmo papel nas mais diferentes cenas. Seu interesse permanente é aperfeiçoarse a si mesmo, e, por onde quer que perambule, seja pelas ruas das cidades, seja pelos bosques nas florestas, mantém firme a sua intenção. Adapta-se às mais diversas situações, sendo por isso incapaz de se contentar com uma única e mesma. Obstinado e inconstante, quer inovar, mas não se satisfaz com uma inovação só. Aprimora-se constantemente, sem, contudo, superar suas imperfeições. Se habita uma caverna, constrói um casebre; se habita um casebre, quer equipá-lo" (Ferguson, 2019, p. 34).
} 
objetos externos ${ }^{155}$. Assim, "a mente pode manter ou perder sua penetração e vigor, o coração pode sentir um afeto mais forte ou mais fraco pelo gênero humano, e é vão, em tais circunstâncias, querer buscar por distinções de virtude e vício, ou acusar de indolência o cidadão só porque ele tem esta ou aquela equipagem ou veste a mesma pele que outrora vestia o selvagem. A vaidade não se distingue por um traje em especial: manifesta-se inclusive no índio americano, em suas ricas plumagens e colares, em suas peles tingidas, no tempo que desperdiça com a pintura" (Ferguson, 2019, p. 338).

Dessa perspectiva, Ferguson recoloca a questão do luxo a fim de qualificar o debate sobre ele. O problema não é “teológico-moral” (Monzani, 1995, p. 54), por isso refuta o argumento daqueles que o desacreditam de forma peremptória ${ }^{156}$. Para ele, "os vícios dos homens não são proporcionais a suas fortunas", nem "os hábitos de avareza e sensualidade" estão "fundados em certos graus de riqueza ou em certas espécies de divertimento" (Ferguson, 2019, p. 341). Segundo Craig Smith (2018) "é muito improvável que Ferguson estivesse preocupado com qualquer ligação causal entre crescimento econômico e corrupção moral" (p. 171), ou seja, que o autor fizesse uma ligação imediata entre riqueza e declínio. No entanto, há sim uma possível consequência danosa do enriquecimento de maneira geral e do luxo em particular, e, por essa razão, Ferguson também rechaça a opinião daqueles que simplesmente o recomendam ${ }^{157}$ :

Seriam por isso desprovidas de fundamento e razão as estimativas dos moralistas mais severos de todas as épocas? Poderíamos nos dispensar do receio de que se cometa um erro, em se tratando do refinamento de artigos de subsistência ou convenientes à vida? $\mathrm{O}$ fato é que, se os homens frequentemente erram, não é porque tenham se habituado a um conforto excessivo ou em função de uma dieta mais requintada, mas sim porque preferem esses artigos em detrimento de seus amigos, de seu país ou dos homens em geral. E, se erram sempre, é porque admiram distinções superficiais ou benefícios frívolos, porque cedem diante dos menores obstáculos e são incapazes de cumprir com brio o seu dever. A consideração moral desse tópico não se destina a constranger os homens a certas espécies de habitação, de dieta ou de roupa, apenas a evitar que transformem meras conveniências no principal objeto de suas vidas. Se nos perguntassem: "Até que ponto deve ir a busca por comodidades triviais, sem desviar o homem de suas obrigações mais importantes?", responderíamos: “Deve ir até onde foi”. Tal é a regra outrora adotada em

\footnotetext{
${ }^{155}$ Vide o primeiro capítulo, sobre a Filosofia Moral.

${ }^{156}$ Como Rousseau. Cf. Rousseau, J.-J. Discurso sobre a origem e os fundamentos da desigualdade entre os homens. São Paulo: Martins Fontes, 2002.

${ }^{157}$ Como Mandeville. Cf. Mandeville, B. A Fábula das abelhas, ou vícios privados, benefícios públicos. Traduzido por Bruno Costa Simões. São Paulo: Editora Unesp, 2017.
} 
Esparta; seu objetivo era preservar a integridade do coração para a comunidade e ocupar os homens no cultivo de sua própria natureza, não no acúmulo de riquezas e bens supérfluos. Os espartanos não esperavam do machado e do serrote uma vantagem política superior à que poderia advir do cinzel e da plaina. Quando Catão caminhou descalço e sem toga pelas ruas de Roma, provavelmente o fez por desdenhar aquilo que seus compatriotas mais admiravam, não porque tivesse a ilusão de que a virtude ou o vício se encontravam neste ou naquele adereço (Ferguson, 2019, pp. 339-340).

A discussão reaparece aqui sob um outro viés: o luxo se torna uma fonte de corrupção quando confunde os homens. O ponto do autor, caro a sua filosofia moral tal como foi exposta anteriormente, é que os objetos externos, nesse caso o luxo, podem confundir os homens, desviando-os de sua verdadeira felicidade, ou seja, da virtude. De modo geral, o luxo seria "ruinoso para o caráter humano" na medida em que se transforma em "uma predileção por artigos de vaidade e mercadorias exorbitantes" (Ferguson, 2019, p. 340).

Em termos nacionais, cabe pensar como o luxo pode ser prejudicial para cada forma de governo. Em Montesquieu, porque o luxo é fruto das "desigualdades de fortunas que existe entre os cidadãos e da desigualdade das riquezas dos diversos Estados" (Montesquieu, 2005, p. 106) ${ }^{158}$, ele é incompatível com as repúblicas, cujo princípio, sobretudo nas democracias, é a igualdade (Montesquieu, 2005, p. 54). Todavia, a questão se torna mais complexa quando tratamos de governos monárquicos e mistos, onde hierarquias desiguais são "tão importantes a esses sistemas" e onde, portanto, "altos graus de luxo parecem salutares e mesmo indispensáveis" (Ferguson, 2019, p. 340). Embora o luxo não seja um problema para esses modelos de governo por conta da desigualdade que engendra, ainda assim ele pode ameaçá-los de duas maneiras.

Um primeiro efeito nocivo do luxo é que ele pode resultar em um relaxamento do espírito nacional, quando apenas a busca por artigos luxuosos ocupa os indivíduos, sem qualquer interferência de perigos públicos a mobilizar seus esforços. O ambiente de tranquilidade, propício à prática das artes comerciais, "se prolongado por muito tempo", tende a fazer com que os homens busquem apenas "vantagens privadas", ou seja, trabalhem em prol apenas de seu próprio interesse, sem qualquer consideração pelo bem público. Dessa forma, o indivíduo se torna "efeminado, mercenário e sensual" (Ferguson, 2019, p. 342), não sendo capaz de exercer as funções civis, tampouco as militares, tão

158 “O luxo é sempre proporcional à desigualdade das fortunas. Se, num Estado, as riquezas são igualmente divididas, não haverá luxo, pois ele só está baseado nas comodidades que obtemos com o trabalho dos outros" (Montesquieu, 2005, p. 105). 
necessárias à manutenção de sua liberdade doméstica e independência externa. Assim, o luxo não é, ele próprio, enervante, mas sua consequência, ou seja, uma vida voltada exclusivamente para sua obtenção, desvia os homens de seu objetivo principal, que é o engajamento político

Igualmente para Hume, no âmbito privado, "as artes não têm esse efeito enervante da mente ou do corpo. Ao contrário, a indústria, sua inseparável companheira, fortalece a ambos" (Hume, 2011, p. 214). Na verdade, ele considera que o luxo ocupa o lugar da "preguiça e da ociosidade", não das questões públicas como pensa Ferguson, sendo assim, preferível e menos nocivo "tanto para pessoas privadas quanto para o público" (Hume, 2011, p. 220). Ademais, Hume vê de modo positivo a "brandura e moderação" que "o conhecimento nas artes do governo gera", pois, dessa forma, "as facções se tornam menos inveteradas; as revoluções menos trágicas; a autoridade, menos severa; as sedições, menos frequentes" (Hume, 2011, p. 214).

Ainda que Ferguson trate dos desvios que a prática das artes pode engendrar, sua preocupação principal, no que concerne ao assunto, diz respeito às posições hierárquicas. Como dissemos, o autor avaliza, conforme a teoria das formas de governo de Montesquieu, a ideia de que "o governo monárquico supõe [...] preeminências, hierarquias e até uma nobreza de origem" (Montesquieu, 2005, p. 36). Esses "poderes intermediários", como os denomina o francês, seriam os responsáveis por moderar o poder soberano do monarca e impor freios à "vontade momentânea e caprichosa de um só” (Montesquieu, 2005, p. 26). Dessa forma, Ferguson afirma que nascimento, títulos e fortuna podem criar subordinação sem que haja grande prejuízo para uma nação, a questão é quando o luxo introduz a falsa noção de que basta ser rico para adquirir distinção.

Sob a forma monárquica em sua plena vigência, uma fortuna maior é de fato uma marca que distingue as diferentes ordens de homens, mas há outras componentes sem os quais a riqueza não é admitida como fundamento para a precedência e em favor das quais chega a ser desprezada e desperdiçada. Refiro-me a nascimento e títulos, à reputação de coragem, às maneiras corteses, a certa elevação do espírito. Supondo-se que essas distinções sejam desconsideradas e a nobreza seja identificada unicamente pelas exuberantes posses que apenas o dinheiro pode conquistar e pelos gastos suntuosos que as fortunas mais recentes são mais aptas a sustentar, deve-se reconhecer que nesse caso o luxo corrompe tanto o Estado monárquico quanto o republicano, e introduz uma fatal dissolução das maneiras que faz com que homens de todas as condições, ansiosos por adquirir e exibir riquezas, deixem de ter outras ambições. Não mostram nem a elevação 
dos nobres nem a fidelidade dos súditos; trocaram por uma vaidade efeminada o senso de honra que dá regras à coragem pessoal; e por um servilismo indigno, a lealdade que liga cada um a seu superior imediato e o todo ao trono (Ferguson, 2019, pp. 343-344, grifo nosso).

Não é suficiente que haja numa monarquia poderes intermediários para se evitar o despotismo do monarca, é preciso que a nobreza tenha "coragem, maneiras corteses e certa elevação de espírito", quer dizer, que possuam certas virtudes para que o senso de honra não se transforme em servilismo. Assim, o autor pensa as ordens superiores de homens como composta por uma nobreza baseada em nascimento e títulos, mas também em virtudes, cuja ocupação não tenha qualquer relação com as atividades lucrativas, apenas com o bem público. De acordo com Iain McDaniel (2013), para Ferguson, “os Estados comerciais precisavam de uma elite não econômica que pudesse servir como 'um objeto de ambição e uma distinção hierárquica a qual os ativos pudessem aspirar"” (p. $100)^{159}$. Dessa forma, ainda que mantida a desigualdade e a subordinação, características das monarquias, a honra ${ }^{160}$ estaria preservada e serviria de centro de gravidade moral para onde convergiriam todas as posições hierarquias, inclusive as mais baixas. No campo político, essa elite se ocuparia das mediações do poder do monarca, e no campo da defesa, das próprias funções militares.

\section{III.v.3. O problema da defesa}

A preocupação de Ferguson com a defesa das nações comerciais modernas decorre também da separação das artes e das profissões, pois enquanto as vantagens obtidas através dela na manufatura são incontestáveis, não se pode afirmar o mesmo da separação observada nos departamentos políticos e militares. Como vimos, no campo político, a fragmentação das atividades faz surgir postos apenas burocráticos, sem qualquer relação com o bem público, e, no campo militar, cria exércitos permanentes, ou seja, exércitos de soldados profissionais dedicados exclusivamente à defesa, sem qualquer

\footnotetext{
${ }^{159}$ Iain McDaniel (2013) nos lembra de que, no caso específico da Grã-Bretanha, Montesquieu aponta "a ausência [..] de um sistema de hierarquias intermediárias" como uma das possíveis causas de instabilidade nacional. O comentador afirma ainda que "a nobreza proprietária de terras perdera seu caráter de poder intermediário como uma consequência de seu engajamento no comércio, das inclinações centralizadoras das monarquias Tudor, e das guerras civis do século XVII" (p. 35).

${ }^{160} \mathrm{Em} O$ Espírito das Leis, Montesquieu diz que "a honra, desconhecida nos Estados despóticos, onde até mesmo muitas vezes não se tem palavra para expressá-la, reina nas monarquias; ali ela dá vida a todo corpo político, às leis e até às virtudes" (Montesquieu, 2005, p. 37).
} 
relação com a vida civil. O estabelecimento de exércitos permanentes na Europa tornouse comum no século XVII ${ }^{161}$, embora o recrutamento de soldados mercenários para compor os exércitos nacionais de civis possa ser remontado à antiguidade. Segundo John Robertson (1985), “o que foi realmente original no exército permanente foi, primeiro, sua disciplina, e, depois, sua relação próxima ao Estado que o organizou e financiou" (p.13). Para Ferguson, no entanto, a disciplina e mesmo o aprimoramento técnico alcançados pela dedicação exclusiva não significam necessariamente um aumento da capacidade bélica. Na manufatura, é a estupidez e a repetição que garantem um bom trabalho; na defesa, ao contrário, é a virtude (Ferguson se refere às virtudes militares, como a coragem) que exerce uma função decisiva.

Se o tesouro de um Estado puder arregimentar bom número de homens e fornecer os equipamentos da guerra, as posses dos medrosos serão facilmente tomadas, a multidão temerosa tombará por si mesma, encostas serão escaladas, pois não haverá valor para defendê-las, e as armas só produzem consequências nas mãos dos valentes (Ferguson, 2019, p. 102).

Assim, não basta que o soldado tenha os melhores armamentos e sejam tecnicamente bem preparados, se moralmente não estão preparados para uma guerra. Se, para Ferguson, a divisão das tarefas não pode ser aplicada à questão da defesa justamente porque nela opera uma lógica diferente daquela da manufatura, ou seja, há uma descontinuidade entre a divisão das profissões de modo geral e a profissão do soldado, para Smith essa aplicação é vista como positiva. Para ele, da mesma forma como em qualquer outra arte, também na arte militar, o exercício e a prática exclusiva da atividade aumentarão a habilidade do profissional; portanto, "a fim de levá-la ao grau de perfeição, é necessário que ela se transforme na única e principal ocupação de uma classe particular de cidadãos, e a divisão do trabalho é tão necessária para seu aperfeiçoamento quanto é para qualquer outra arte" (Smith, 1981, vol. II, p. 697). Nesse sentido, como nas sociedades comerciais os indivíduos não têm tempo livre para o exercício militar, a formação de milícias compostas de cidadãos se torna inferior à criação de um exército permanente dedicado exclusivamente às questões de defesa ${ }^{162}$.

161 “O exército permanente não incorporou uma concepção estratégia original: foi simplesmente construída sob a superioridade da infantaria estabelecida pelos suíços e espanhóis no começo do século XVII. Tampouco significou uma mudança imediata na composição e no recrutamento. As forças holandesas e suecas no início do século XVII, a francesa no final do mesmo século, e a britânica no século XVIII incluíam regularmente um considerável contingente de mercenários” (Robertson, 1985, p. 13).

162 Como vimos na seção sobre a divisão do trabalho, Smith questiona o fato de que, no progresso da sociedade, o espírito marcial não seja exercitado. No entanto, o autor reitera que "nos tempos atuais, de 
Ferguson se preocupa exatamente com o fato de que os cidadãos, principalmente das classes superiores, não tenham tempo para as atividades militares nas sociedades comerciais, pois, dessa forma, produzem riquezas sem ser capazes de defendê-las. Isso significa que o surgimento de exércitos permanentes é uma ameaça sobretudo porque gera uma cisão entre cidadãos e soldados. Segundo ele, um cidadão romano, que exercia igualmente a função militar, dificilmente acreditaria que "um dia nações refinadas e inteligentes reduziriam a arte da guerra a umas poucas formalidades técnicas, que cidadãos e soldados seriam tão separados quanto homens e mulheres, que o cidadão teria uma propriedade que não teria de defender nem saberia como fazê-lo, que o soldado seria designado para defender algo que outro fora ensinado a desejar, e que apenas ele mesmo saberia como capturar e preservar em sua posse, que, em suma, um grupo de homens teria interesse na preservação de instituições civis, sem ter o poder de defendê-las, enquanto outro teria esse poder, mas sem qualquer inclinação ou interesse em exercê-lo" (Ferguson, 2019, p. 318).

Para entendermos como Montesquieu discute a questão militar na Inglaterra, retomemos sua reflexão sobre a divisão dos poderes: numa monarquia moderna tal como a inglesa, a liberdade só está assegurada se o poder executivo do monarca for moderado por meio de um corpo legislativo, composto de nobres (Montesquieu, 2005, p. 172), além de "um poder de julgar" que "deve ser exercido por pessoas tiradas do seio do povo em certos momentos do ano" (Montesquieu, 2005, p. 169). No que concerne à defesa, o autor afirma:

Para que aquele que executa não possa oprimir, é preciso que os exércitos que se lhe confiam sejam do povo e tenham o mesmo espírito do povo, como aconteceu em Roma até a época de Mário. E, para que seja assim, só existem dois meios: ou que aqueles que são empregados no exército possuam bens suficientes para responder por sua conduta perante os outros cidadãos e só estejam alistados por um ano, como se praticava em Roma; ou, se se possui um corpo de tropas permanente, onde os soldados são uma das partes mais vis da nação, é preciso que o poder legislativo possa dissolvê-lo quando quiser, que os soldados morem com os cidadãos e que não haja nenhuma acampamento separado, nem caserna, nem praça de guerra (Montesquieu, 2005, pp. 176-177).

fato, somente aquele espírito marcial [do povo como um todo], e sem o suporte de um exército permanente bem disciplinado, talvez não seja suficiente para a defesa ou segurança de qualquer sociedade (Smith, 1981, p. 787). 
Portanto, o que Montesquieu sugere é que se formem milícias de nobres, quer dizer, de cidadãos cuja fortuna garanta-lhes independência do Estado, ou que se criem exércitos permanentes, regulados pelo legislativo, mas controlados pelo poder executivo $^{163}$. Em ambos os casos, o poder militar não se confunde com o poder civil, evitando, assim, que "as mesmas pessoas não tenham ao mesmo tempo a confiança do povo e a força para dele abusar" (Montesquieu, 2005, pp. 79-80). Foi exatamente o que ocorreu em Roma: o poder civil e militar de homens como César permitiu-lhes apropriar da República de forma irrestrita, tornando-se verdadeiros déspotas.

Ora, no Ensaio, Ferguson critica a confiança que a modernidade tem nos exércitos permanentes ${ }^{164}$, mas não chega a propor textualmente a formação de milícias, embora não se furte a exortar as classes superiores de homens a se engajarem nas questões políticas e militares do país. Situação diferente é a do panfleto lançado em 1756 e intitulado Reflexões anteriores ao estabelecimento de uma milícia ${ }^{165}$.

Ferguson inicia o panfleto mostrando que, embora os exércitos britânicos, nas guerras anteriores, tenham mostrado força e triunfado sobre seus inimigos, na Guerra dos Sete Anos (guerra que a Grã-Bretanha travou contra a França e seus aliados entre 1756 e 1763), "quando engajados isoladamente contra um inimigo poderoso, sentiram, igualmente, sua fraqueza" (Ferguson, 1756, p. 2). A partir desse contexto, Ferguson propõe o estabelecimento de uma milícia, que, segundo ele, "misturaria o espírito militar com nossa política civil e comercial" (Ferguson, 1756, p.3)

A discussão que baseia a proposta de Ferguson, que está também no Ensaio, é a de como o desenvolvimento do comércio engajou, não só os cidadãos comuns, mas até a

\footnotetext{
${ }^{163}$ Sobre a necessidade de o poder executivo comandar o exército, Montesquieu afirma que "é da maneira de pensar dos homens que se valoriza mais a coragem do que a timidez; a atividade do que a prudência; a força do que os conselhos. O exército sempre desprezará um senado e respeitará seus oficiais. Não dará importância às ordens que lhe serão enviadas da parte de um corpo composto de homens que achará tímidos e por isso indignos de comandá-los. Assim, tão logo o exército depender unicamente do corpo legislativo, o governo se tornará militar" (Montesquieu, 2005, p. 177).

${ }^{164} \mathrm{Um}$ exemplo dessa crítica pode ser encontrado nesta passagem do Ensaio: "Em certos casos, a divisão das artes e profissões tende a aperfeiçoar sua prática e a promover seus fins. Graças à separação das artes do tecelão e do sapateiro, temos roupas e sapatos melhores. Mas separar as artes que formam o cidadão e o estadista, as artes da política e da guerra, equivale a desmembrar o caráter humano e destruir as artes que alegamos melhorar. Essa separação tem o efeito de privar um povo livre do que é necessário à sua segurança e abre o flanco para uma eventual invasão estrangeira que terminaria em usurpação e na instalação de um governo militar" (Ferguson, 2019, p. 317).

${ }^{165}$ De acordo com John Robertson, no século XVIII, "o problema da defesa nacional e da organização militar apresentou-se como central para a investigação do Iluminismo Escocês sobre 'o progresso da sociedade""; ainda, "a concepção da demanda e organização das agitações pode ser atribuída a um grupo particular dos literati de Edimburgo, os 'moderados', liderados (nesta ocasião) pelo Reverendo Alexander Carlyle e Adam Ferguson" (Robertson, 1985, p. 8).

${ }^{166}$ A proposta de Ferguson no panfleto Reflexões anteriores ao estabelecimento de uma milícia (1756) tem em vista o contexto da Guerra dos Sete Anos. Posteriormente, ela servirá de inspiração para a proposição de uma milícia escocesa, encabeçada pelo Reverendo Alexander Carlyle, e com a participação ativa de Ferguson.
} 
nobreza proprietária de terras, nas artes lucrativas. O problema é que a nobreza, que historicamente se dedicava, por honra e glória, ao exército, agora também tem preferido essa forma de enriquecimento. Em seu plano para o estabelecimento de uma milícia, Ferguson propõe restaurar a participação dos proprietários de terra na defesa nacional, pois é preciso que a força militar esteja "nas mãos daquela parte da nação que é a menos corrompida e a mais confiável para estar encarregada da paz interna" (Ferguson, 1756, p. 19), isso quer dizer que, como para Montesquieu, a nobreza tem um papel fundamental justamente porque é independente economicamente. Porém, como "a autodefesa é um assunto de todos" (Ferguson, 1756, p. 12), a milícia pode incluir as ordens inferiores de homens, desde que subordinados hierarquicamente às ordens superiores; assim, os nobres e os cavalheiros cuja riqueza fosse maior ocupariam a posição de coronéis, depois, os de menor riqueza, seriam os oficiais; essa hierarquia descenderia até alcançar os homens de classes inferiores, mas que fossem indivíduos na posse dos direitos civis e políticos (freemen) e também “respeitáveis na comunidade" (Ferguson, 1756, p. 50). Ferguson exclui nessa composição os indivíduos cuja posição social muito baixa os torna dependentes de seu próprio trabalho e de um patrono, são os "aldeões, os tarefeiros e os criados" (Ferguson, 1756, p. 51).

Nas Reflexões, o autor trata igualmente da objeção de que a milícia seria um perigo maior para a liberdade doméstica do que os exércitos permanentes. De acordo com essa posição, é perigoso dar força militar a homens que, de forma geral, estão divididos em partidos e facções, o que poderia resultar, como em Roma, no surgimento de líderes populares que, com suas legiões próprias e ambições particulares, viriam a usurpar o poder nacional através da força. Ora, segundo Ferguson, o governo militar só surgiu em Roma porque já havia uma corrupção no seio da República, e, ao contrário do cenário de César e Pompeu, em que "o zelo pelo país estava perdido”, na Grã-Bretanha, "as ideias de uma constituição permanecem" (Ferguson, 1756, p. 26), isto é, não há uma corrupção generalizada. $\mathrm{O}$ autor rebate esse argumento afirmando que na verdade há semelhança maior entre os soldados dos exércitos permanentes e as tropas de César e Pompeu:

O perigo aqui apontado está distante; e aquele de uma conquista estrangeira é muito mais iminente. Não podemos negar, portanto, que uma força militar é necessária para defender nosso país; e aqueles que insistem nessa objeção contra uma milícia popular apenas, estão interessados em mostrar que o crescimento de um exército permanente é, na ocasião, menos perigoso para a liberdade. Mesmo o exemplo que citamos confirmará a direção de tal posição. César e mesmo Pompeu encontraram sua força naquelas legiões que comandaram por muito tempo em diferentes províncias, tropas formadas sob todos os 
vícios e desvantagens de um exército permanente: a ocasião é, portanto, mais uma prova do perigo daquele quartel (Ferguson, 1756, pp. 27-28).

A milícia proposta por Ferguson não somente se assemelha, como prescreveu Montesquieu, ao exército de cidadãos da antiguidade, sobretudo de "Roma até a época de Mário" (Montesquieu, 2005, p. 176), mas igualmente às forças militares da Europa nos séculos anteriores, em que a nobreza era responsável pela sua defesa. Ferguson, nas Reflexões, faz menção a esse passado:

Qualquer um se lembrará, nesta ocasião, que nossos ancestrais não estavam acostumados com exércitos permanentes; que o povo fora outrora, não somente suficiente para sua própria defesa, mas com frequência conduzia guerras exitosas contra o país inimigo. Sua bravura e espírito marcial serão enaltecidos para servir como um exemplo para o tempo presente, e para silenciar aqueles que pretendem tratar a milícia popular com desprezo. Os exemplos de muitas eras na Europa, os mais recentes casos de milícias se opondo de forma bem-sucedida a exércitos regulares, provará que o que se propõe e que parece ser tão sinceramente desejado por essa nação, não é impraticável (Ferguson, 1756, p. 5).

Mas esse apoio de Ferguson à formação de milícias não significa que o autor proclamava uma volta ao passado medieval, nem que se mostrava favorável a poderes militares locais e independentes, tais como prevaleceram nas Terras Altas da Escócia até o século XVIII; sua proposta, embora se refira ao estabelecimento de regimentos em cada condado, tem em vista uma unidade nacional e de ação conjunta para a defesa contra inimigos externos. Além disso, na modernidade, as questões que estão colocadas são outras: é o espírito do comércio que parece atrapalhar o espírito marcial, pois, segundo Ferguson, nesse contexto, "nós consideramos o sucesso da manufatura; porém, deslocamos as honras da natureza humana: provemos um bom trabalho, mas formamos homens grosseiros, sórdidos, vazios de sentimento e de maneiras, que estão sujeitos a serem pilhados, insultados e derrotados pelos inimigos de seu país" (Ferguson, 1756, p. 12).

Embora se dedique a tratar das questões relativas à segurança, o autor deixa claro, no Ensaio, que o principal objetivo das nações não é simplesmente o desenvolvimento da arte militar, pois é "na condução dos negócios relativos à sociedade civil, os homens encontram exercício para seus melhores talentos e o objeto de seus melhores afetos" (Ferguson, 2019, p. 223). Sua preocupação principal é com a estabilidade doméstica das nações comerciais modernas, em especial da Inglaterra. A 
ideia da milícia, em Ferguson, é vista como um meio para atingir esse fim: “[...] as nações devem ajustar sua política à possibilidade de guerras no estrangeiro, elas devem igualmente manter a paz doméstica. Mas não pode haver paz quando não há justiça. Ela pode resistir a divisões, disputas e opiniões contrárias, mas não a erros deliberados" (Ferguson, 2019, pp. 223-224). Assim, para equacionar segurança externa com liberdade interna, a participação das ordens superiores de homens na milícia tem uma função muito mais ampla que somente a da defesa contra países inimigos, ela é uma forma de ativismo cívico, cujo objetivo último é evitar o relaxamento do espírito nacional e até mesmo a escravidão política. 


\section{Conclusão}

Como dissemos, Claude Guatier (2011) afirma que "Ferguson faz uma ligação entre o declínio das nações e a corrupção dos indivíduos" (p. 93). Na verdade, há uma relação anterior a essa na filosofia fergusoniana entre virtude individual e felicidade nacional. Ora, o autor estabelece como lei fundamental da moralidade que a destinação dos homens é o bem do gênero humano. No Ensaio, Ferguson redefine sua noção de virtude a fim de dar a ela um caráter definitivamente político-social; dessa forma, o espírito público "fundado na benevolência" e cujo "objeto é indefinido: homens e naturezas inteligentes, onde quer que se apresentem a nossa consideração ou concepção" (Ferguson, Instituições, 2019 , p. 427) - torna-se a virtude principal. Isso implica que a virtude do indivíduo esteja relacionada com a vida em sociedade, ou melhor, que tenha em vista o bem público. Uma nação feliz é, portanto, aquela em que seus membros não agem apenas com vistas à sua felicidade individual ou ao seu interesse próprio, ao contrário, eles trabalham com zelo e ardor em prol de toda comunidade, em benefício comum. Dessa forma, a relação apontada pelo comentador francês entre corrupção e declínio é apenas um desdobramento de uma premissa moral expressa de antemão na filosofia moral do autor, entre virtude e felicidade nacional.

A concepção de nação virtuosa não é meramente formal ou abstrata, ela está diretamente ligada à própria capacidade dos homens enquanto corpo coletivo de se desenvolverem e alcançarem a grandeza e a eminência. No entanto, a dificuldade é conciliar essa ideia moral de sociedade com outra, deduzida do fato da sociabilidade da natureza humana, própria da espécie e regida por leis físicas. Se o progresso social, como o próprio autor determina, independe formalmente de causas morais (Ferguson admite, mais precisamente, causas físicas, como localização geográfica e clima), uma vez que é necessário, como então entender que a felicidade das nações interfere nesse progresso?

Esse é um problema que perpassa a filosofia de Ferguson como um todo e que, na nossa avaliação, não é completamente resolvido. Como vimos, há, na epistemologia do autor, uma divisão das leis naturais entre lei física e lei moral. Essa divisão permite que abordemos as questões humanas sob dois diferentes vieses: primeiro, sob um ponto de vista factual, tratamos dos fenômenos da vida humana, buscando causas eficientes para formar sua ciência, depois, a partir da existência moral dos homens, compilamos leis (obrigatórias) para formar a filosofia moral. Com essa decomposição, considera-se, por um lado, o progresso natural e necessário da sociedade (enquanto generalização da 
trajetória particular das nações), cuja dinâmica se apresenta na forma de um equilíbrio espontâneo, e, por outro, um progresso moral e teleológico das nações. Se não é fácil estabelecer de que forma essas duas concepções se inter-relacionam, é possível, ao menos, reformular a questão da seguinte maneira: toda nação virtuosa progride, mas nem toda nação que progride é virtuosa.

Dessa perspectiva, uma nação pode alcançar o estágio mais avançado de seu desenvolvimento sem se tornar uma civilização, no sentido moral que Ferguson dá ao conceito. Ora, julgar se uma nação é ou não civilizada importa para o filósofo político, pois se pode avaliar, desse modo, a possibilidade de seu declínio. Com efeito, a problemática epistemológica se resolve na discussão sobre o declínio: o declínio, ao contrário do progresso, não é natural, portanto, é possível estabelecer suas causas morais sem incorrer em contradições teóricas. A filosofia política encontra para si um solo seguro.

A corrupção do espírito público é a principal causa do declínio de uma nação; mas é preciso ainda determinar as razões dessa corrupção, que, para Ferguson, é tratado enquanto relaxamento do espírito público. Essas razões são circunstanciais, quer dizer, dependem de uma série de fatores particulares de cada nação, porém, ainda assim, é possível estabelecer regras gerais. A história da sociedade, por conter uma teoria de estágios, é um expediente útil que nos permite reconhecer regularidades entre trajetórias de nações muito diferentes, como é o caso de Roma e da Inglaterra. Na República romana, o espírito público foi corrompido pela grandeza territorial, e sua decadência é descrita a partir desse fato: desvirtuamento do exército, mudança no sistema político e governo militar. A Inglaterra, como outras nações modernas, ainda que sob a ameaça do imperialismo, pode ruir sobretudo por causa do progresso do comércio. No entanto, não é o enriquecimento, tampouco a desigualdade engendrada por ele que se configura como um perigo: a questão é que o avanço do comércio depende da separação das artes e das profissões. Essa separação gera dois problemas: por um lado, aliena não somente as classes mais baixas de homens, mas também as mais altas, fazendo com que ambas se ocupem apenas com suas atividades particulares; por outro, cria departamentos meramente burocráticos na política e na defesa, desobrigando os cidadãos das tarefas públicas. Esses dois elementos podem ser responsáveis pelo relaxamento do espírito público. As previsões de Ferguson para o declínio de um Estado moderno como o inglês seguem, de forma bastante próxima, o exemplo romano: enfraquecimento do exército, desestabilidade política e governo militar. 
Mesmo tendo estabelecido esse roteiro, Ferguson faz uma consideração sobre a relação entre riqueza e declínio. Quando acrescenta uma seção sobre como a riqueza das nações pode causar sua ruína, desviando-se do seu principal objetivo no Ensaio, que é tratar da política sob a ótica das maneiras (do caráter) de um povo - um dos recursos nacionais, além da própria riqueza e do número populacional -, o autor dialoga mais diretamente com seus contemporâneos, principalmente Hume e Smith. Tanto este quanto aquele estavam igualmente preocupados com os rumos dos Estados europeus modernos, porém, de modo diferente de Ferguson, suas preocupações diziam respeito a questões mais diretamente ligadas ao sistema político e ao desenvolvimento do comércio, ou seja, à economia política, evitando, sobretudo Hume, discutir o declínio a partir de um vocabulário moral.

Hume, no ensaio "Que a política pode ser reduzida a uma ciência” procurou desvincular a ciência política de uma discussão sobre os "humores e temperamentos" (Hume, 2011, p. 24) dos homens, tentando alçá-la a um patamar mais científico, em que pesasse os arranjos institucionais, não simplesmente o caráter dos governantes e governados. Além disso, dedicou-se, em diversos outros ensaios, a tratar de assuntos relacionados ao comércio e à produção de riquezas (segundo o autor, no ensaio Do comércio, são os discursos sobre comércio, moeda, juros, balança comercial etc.). Com tais temas, Hume refletiu sobre a estabilidade política das nações europeias a partir de um viés "moderno", e não da tradição antiga, com sua terminologia de corrupção e virtude.

Entretanto, ainda que Hume tenha "sobreposto à linguagem do historicismo do humanismo cívico", de virtude e corrupção, "uma linguagem de economia do século XVIII” (Hont, 1983, p. 272), ele não superou uma visão de mundo que relacionava crescimento e declínio, ou seja, uma concepção cíclica da história, em que o declínio de uma nação é consequência natural depois de um longo período de crescimento ${ }^{167}$. Para o autor, uma nação rica poderia ruir por causa de um limite intrínseco ao comércio, quer dizer, haveria uma restrição natural ao próprio progresso das artes comerciais ${ }^{168}$.

\footnotetext{
167 Segundo Duncan Forbes (1975), foi um "aspecto da teoria econômica de Hume" a inclusão de um determinismo "do tipo pêndulo oscilante, de acordo com o qual um movimento ou processo histórico, como a idade das trevas depois das invasões germânicas e a queda do império romano, tendo alcançado um extremo em uma direção deve começar a se mover no sentido oposto" (p. 190)

168 “A visão filosófica da liberdade britânica e da constituição britânica envolveu também uma doutrina não mencionada até aqui, e que pertence ao lado fraco, 'mecânico' da filosofia de Hume e deve carregar em larga medida a responsabilidade por sua atitude de prostração; que 'o crescimento de tudo, tanto nas artes e natureza, ao fim restringe-se a si mesmo' (Letters, I, 143, Novembro, 1750). 'Grandes impérios, grandes cidades, grande comércio, todos eles sofrem uma restrição, não de eventos acidentais, mas de princípios necessários' (Letters, I, 272)” (Forbes, 1975, pp. 189-190).
} 
Em sentido contrário, Ferguson, rejeita essa concepção de história cíclica. Porém, ainda que o declínio não seja natural, ele é uma ameaça real ao futuro das nações. $\mathrm{Na}$ verdade, para Ferguson pode haver uma relação circunstancial entre crescimento ou grandeza e decadência, que não diz respeito a um limite do próprio comércio, como queria Hume, nem à corrupção causada pelo luxo, segundo a tradição republicana. Sua preocupação é eminentemente política:

Se instituições nacionais calculadas para a preservação da liberdade, em vez de conclamarem o cidadão a agir por si mesmo e defender seus direitos, oferecessem segurança, sem exigir como contraparte nenhuma atenção ou esforço, esse arranjo de governo, aparentemente perfeito, resultaria no enfraquecimento dos laços de sociedade e, com suas máximas de independência, afastaria e alienaria as diferentes ordens hierárquicas que deveria conciliar. Não haveria lugar nem para os partidos que se formam em repúblicas, nem para as assembleias de cortesãos que se reúnem em governos monárquicos, pois, na falta do sentido de interdependência entre seus membros, que as justifica, não teriam por que se reunir. As praças de comércio continuariam a ser frequentadas, e apenas distrações banais seriam apreciadas coletivamente, enquanto o domicílio privado se tornaria um local de reserva, longe dos aborrecimentos decorrentes de preocupações e atenções mútuas, estas consideradas pelo credo político como inócuas e mesmo desprezíveis no que se refere à honra (Ferguson, 2019, p. 268).

Assim, mesmo que o espírito do comércio trouxesse diversos avanços para os Estados da Europa, tanto na produção sem precedentes de riquezas, quanto na suavização das maneiras, e sobretudo na estabilidade das instituições políticas, essa grandeza poderia carregar em si o germe da ruína. Ferguson via no cenário de tranquilidade proporcionado pelo comércio, paradoxalmente, uma fonte de corrupção, pois havia transformado os cidadãos (o "zoon politiokon" aristotélico), que outrora frequentavam a ágora para defender sua liberdade, em meros mercadores (em "homo economicus"), que se relacionam coletivamente apenas nas "praças de comércio". Ele questionou a capacidade do comércio de criar novas formas de sociabilidade que estivessem de acordo com o bem público e a liberdade dos indivíduos. Com efeito, diferentemente de Smith e Hume, que viam positivamente a tranquilidade como uma oportunidade para o lazer necessário às atividades contemplativas e filosóficas, Ferguson estava preocupado com "a capacidade de ação política autônoma", a qual considerava "essencial para neutralizar outras tendências debilitantes na sociedade moderna" (Winch, 1979, pp. 25-26). Quiçá por essa razão, Ferguson não intentou, mesmo em sua atividade filosófica, se afastar das questões 
políticas, acreditando que com seus escritos e mesmo com seus cursos na Universidade de Edimburgo pudesse influenciar as elites políticas de seu país. De modo similar, via na formação de milícias uma maneira de engajar os proprietários de terra na defesa nacional.

Duncan Forbes (1966) afirma, como nos lembra Norbert Waszek (2014), que Ferguson "observou, calma e detidamente, ambos os lados da medalha da civilização moderna", não para tomar o partido da antiguidade, mas justamente para denunciar "o paradoxo do progresso do comércio" (p. xiii). A filosofia política de Ferguson, ainda que tenha causado incômodo a Hume por sua veia moralizante e pela defesa das virtudes marciais, foi uma contribuição para a economia política nascente no período, sobretudo por questionar a força das relações comerciais, isto é, da produção e da circulação de riquezas na constituição do molde da sociedade civil. Realçando assim, de maneira própria e original, e certamente enfática, uma preocupação de fundo no pensamento de Hume, e, principalmente no de Smith, a saber, a influência desestabilizadora do comércio nas estruturas hierárquicas que sustentam a ordem político-social. Ferguson nos obriga a reconsiderar a economia política "clássica" como um saber mais nuançado e mais crítico do que se costuma pensar. 


\section{Referências bibliográficas}

\section{Fontes}

FERGUSON, A. Reflections previous to the Establishment of a Militia. London: Printed for R. and J. Dodsley, 1756.

Analysis of Pneumatics and Moral Philosophy: For the use of Students in the College of Edinburgh. Edinburgh: sold by A. Kincaid and J. Bell, 1766. Institutes of Moral Philosophy: For the Use of Students in the College of Edinburgh. Edinburgh: Kincaid \& Bell, 1769. Principles of Moral and Political Science. In two volumes. Edinburgh: printed for A. Strahan and T. Cadell, 1792. An Essay on the History of Civil Society. Edited by Fania OzSalzberger, Cambridge: Cambridge University Press, 1995.

. The Correspondence of Adam Ferguson. 2 vols, ed. Vincenzo Merole. London: William Pickering, 1995.

The Manuscripts of Adam Ferguson. Ed. Vincenzo Merolle. London:

Pickering \& Chatto, 2006.

Lectures on Pneumatics and Moral Philosophy. Notes from 1775-

1785. Lectures 1-34; 85-103. University of Edinburgh. Transcription by David Kettler, 13 April 2007.

Essai sur l'histoire de la société civile. Traduction, introduction notes et index par Patrick Vieu, Lyon : ENS Éditions, 2013.

. Ensaio sobre a história da sociedade civil. Tradução de Pedro Paulo

Pimenta. Seguido de Instituições de Filosofia Moral, tradução de Eveline Campos Hauck. São Paulo : Editora UNESP, 2019.

BACON, F. Selected Philosophical Works. Ed. Rose-Mary Sargent. Indianapolis: Hackett Publishing Company, 1999.

The New Organon. Ed. By Lisa Jardine and Michael Silverthorne. Published by Cambridge University Press (Virtual Publishing), 2000.

O Progresso do Conhecimento. Tradução, apresentação e notas Raul Fiker. São Paulo: Editora UNESP, 2007. 
Novo Órganon. Tradução e Notas de Daniel M. Miranda, São Paulo : EDIPRO, 2014.

BUFFON, G. Oeuvres Complètes de Buffon. Suite de L'Histoire des Animaux. Par M.

A. Richard et par Le Baron Cuvier, Paris: Delangle-Frères, 1827.

Oeuvres Complètes de Buffon. Par M. A. Richard, Paris: Pourrat Frère, 1833.

De l'homme. Présentation et notes de Michèle Duchet, Paris: François Maspero, 1971.

Histoire naturelle. Édition et choix de Jean Varloot, Paris : Gallimard, 1984.

CARLYLE, A. Autobiography. $3^{\text {rd }}$ ed. Edinburg and London: William Blackwood and sons, 1861.

CÍCERO. Do sumo bem e do sumo mal. São Paulo: Martins Fontes, 2005.

DIDEROT, D. Enciclopédia, ou Dicionário razoado das ciências, das artes e dos ofícios. Volume 3: Ciência da Natureza. Organização e tradução Pedro Paulo Pimenta e Maria das Graças de Souza, São Paulo: UNESP, 2015.

HOBBES, T. Leviathan. Oxford: Oxford University Press, 1998.

HUME, D. The Letters of David Hume. Edited by J. Y. T. Greig. Oxford: Oxford University Press, vol. 2, 1968.

. Enquiries Concerning Human Understanding and Concerning the

Principles of Morals. Reprinted from the 1777 edition, with introduction and Analytical Index by L. A. Selby-Bigge, and notes by P. H. Nidditch, New York: Oxford University Press, 1975.

. Essays, Moral, Political and Literary, Indianapolis: Liberty Fund, 1994. . Investigação sobre o entendimento humano. Tradução de José Oscar de Almeida Marques. São Paulo: Editora UNESP, 2004.

A arte de escrever ensaio. Tradução de Márcio Suzuki e Pedro Paulo Pimenta. São Paulo: Editora Iluminuras, 2008.

. Tratado da natureza humana. Tradução de Déborah Danowski. São Paulo, Editora UNESP, 2009.

HUTCHESON, F. An Essay on the Nature and Conduct of the Passions and Affections, with Illustrations on the Moral Sense, Indianapolis: Liberty Fund, 2002. Inquiry into the Original of our Ideas of Beauty and Virtue: in two treatises. Indianapolis: Liberty Fund, 2008. 
LOCKE, J. An Essay concerning Human Understanding. 12th ed. London: Rivington, 1824.

MANDEVILLE, B. A Fábula das abelhas, ou vícios privados, benefícios públicos. Traduzido por Bruno Costa Simões. São Paulo: Editora Unesp, 2017.

MARX, K. Capital: a Critique of Political Economy. Chicago: Charles H. Kerr \& Company, v. I, 1909.

MONTESQUIEU, C. Considérations sur les causes de la grandeur de Romains et de leur décadence. Présentation par Jean Ehrard. Paris: Garnier-Flammarion, 1968.

Considerações sobre as causas da grandeza dos romanos e de sua decadência. Rio de Janeiro: Contraponto, 2002.

Lettres Persanes. Édition de Jean Starobinski. Éditions

Gallimard, 2003.

O Espírito das Leis. São Paulo: Martins Fontes, 2005.

NEWTON, I. Principia: Princípios Matemáticos de Filosofia Natural. 2 vols. São Paulo: EDUSP, 2012.

PLATÃO. A República. São Paulo: Martins Fontes, 2014.

ROUSSEAU, J.-J. Discours sur l'origine et les fondements de l'inégalité parmi les hommes. Folio Essais: édition établi par Jean Starobinsli, France: Éditions Gallimard, 1969.

Discurso sobre a origem e os fundamentos da desigualdade entre

os homens. Tradução Maria Ermantina Galvão. Precedido de Discurso sobre as ciências e as artes. São Paulo: Martins Fontes, 2002.

SMITH, A. The works of Adam Smith. With an account of his life and writings by Dugald Stewart, in 5 vols., London: printed for T. Cadell and W. Davies, 1811.

The Theory of Moral Sentiments. Edited by D. D. Raphael and A. L. Macfie. Indianapolis: Liberty Fund, 1976.

. Lectures on Jurisprudence. The Glasgow Edition of the Works and

Correspondence of Adam Smith. Ed. By R. L. Meek, D. D. Raphael and P. G. Stein. Oxford: Clarendon Press, 1978.

. An Inquiry into the Nature and Causes of the Wealth of Nations. Ed. By

R. H. Campbell and A. S. Skinner, Indianapolis: Liberty Fund, 1981.

VOLTAIRE. Philosophical letters, or, Letters regarding the English nation. Edited by John Leigh; translated by Prudence L. Steiner, Indianapolis: Hackett Publishing Company, Inc., 2007. 


\section{Estudos}

ALTHUSSER, L. Montesquieu, la politique et l'histoire. Paris: Presses Universitaires de France, 1959.

BERRY, C. The idea of commercial society in the Scottish Enlightenment. Edinburgh: Edinburgh University Press, 2013.

Essays on Hume, Smith and the Scottish Enlightenment. Edinburgh: Edinburgh University Press, 2018 (a).

Adam Smith: A very short introduction. Oxford: Oxford University Press, 2018 (b).

BINOCHE, B. Les Trois Sources des Philosophies de L'Histoire (1764-1798). Paris: Hermann, 2013.

Introduction à $L$ 'Esprit des Lois de Montesquieu. Paris: Publications de La Sorbonne, 2015.

BROADIE, A. (Ed.). The Cambridge Companion to the Scottish Enlightenment. Cambridge University Press, 2003.

BRYSON, G. Man and Society - The Scottish Inquiry of the Eighteenth Century. New Jersey: Princeton University Press, 1945.

CARRIVE, P. L'Idée d'"Histoirre Naturelle de L'Humanité" chez les Philosophes Écossais du XVIIIe Siècle. In.: Entre Forme et Histoire. Présentation par Olivier Bloch, Bernard Balan et Paulette Carrive. Paris: Meridiens Klincksieck, 1988.

CARROL, A. N. Preparing the Youth Mind for Virtuous Action: Adam Ferguson at the University of Edinburgh. 2007. 69 f. (Masters thesis) - North Carolina State University, Raleigh, 2007.

COUSIN, M. Cours d'Histoire de la Philosophie Morale au dix-huitième siècle. Paris: Librarie de Ladrange, 1840.

DAY, J. P.. The Uniformity of Nature. American Philosophical Quartely, University of Illinois Press (North American Philosophical Publications), Vol. 12, No. 1 (Jan., 1975), pp. 1-16.

DEDIEU, J. Montesquieu et la tradition politique anglaise en France: les sources anglaises de L'Esprit de lois. Victor Lecoffre, 1909.

DELEULE, D. Francis Bacon et la réforme du savoir. Paris: Hermann, 2010.

DUCHET, M. Anthropologie et Histoire au Siècle des Lumières. Paris: Albin Michel, 1995. 
FORBES, D. "Introduction" to Adam Ferguson, An Essay on the History of Civil Society (1776), ed. Duncan Forbes. Edinburgh: Edinburgh University Press, pp. xiixli, 1966.

Hume’s Philosophical Politics. Cambridge: Cambridge University Press, 1975.

GAUTIER, C. Adam Ferguson, An Essay on the History of Civil Society: nature, histoire et civilisation. Paris: PUF, 2011.

GEUNA, M. Republicanism and Commercial Society in the Scottish Enlightenment: the case of Adam Ferguson. In.: Republicanism: A shared European Heritage. Edited by M. van Geldern and Q. Skinner. Cambridge: Cambridge University Press, 2002, pp. 177-196.

GONTHIER, U. Montesquieu and England. London: Pickering \& Chatto Limited, 2010.

HAMOWY, R. The Political Sociology of Freedom: Adam Ferguson and F. A. Hayek. Cheltenham: Edward Elgar, 2005.

HEATH, Eugene, and MEROLLE, Vincenzo, eds. Ferguson: Philosophy, Politics and Society. London: Pickering and Chatto, 2009.

HILL, L. Two Eighteenth Century Visions of the New Civil Society: Adam Smith and Adam Ferguson on the Effects of Modernity. In: AUSTRALASIN POLITICAL STUDIES, 2003, Hobart. Proceedings... Hobart: University of Tasmania, 2003. Adam Smith, Adam Ferguson and the division of labor. In: AUSTRALASIAN POLITICAL STUDIES, 2004, Hobart. Proceedings... Hobart: University of Adelaide, 2004.

Passionate Society: the social, political and moral thought of Adam Ferguson. Netherlands: Springer, 2006.

HILL, J. Adam Ferguson and Ethical Integrity. Lexington Books, Maryland, 2017.

HONT, I. and IGNATIEFF, M. Wealth and Virtue: The Shaping of Political Economy in the Scottish Enlightenment. Cambridge: Cambridge University Press, 1983.

INWOOD, B. (ed). The Cambridge Companion to The Stoics. New York: Cambridge University Press, 2003.

KETTLER, David. The Social and Political Thought of Adam Ferguson. Columbus: Ohio State UP, 1965.

KOSELLECK, R. Three burgerliche Worlds? Preliminary Theoretical-Historical Remarks on the Comparative Semantics of Civil Society in Germany, England, and France. In.: The Practice of Conceptual History: Timing History, Spacing Concepts. 
Translated by Todd Samuel Presner and Others Foreword by Hayden White, Stanford: Stanford University Press, 2002.

LEHMANN, W. C. Adam Ferguson and the Beginnings of Modern Sociology: an Analysis of the Sociological Elements in his Writings with some Suggestions as to his Place in the History of Social Theory. London: Columbia University Press, 1930.

MALHERBE, M. Quelque considérations sur l'idée de civilisation: Hume et Ferguson.

In.: Les Équivoques de La Civilisation, sous La direction de Bertrand Binoche, Seyssel: Éditions Champ Vallon, pp. 163-183, 2005.

MCDANIEL, I. Adam Ferguson in the Scottish Enlightenment. London: Harvard University Press, 2013.

MCRAE, D. G. Adam Ferguson: The Founding Fathers of Social Science. T. Raison (Ed.) Harmondsworth, Mx: Penguin, 1969.

MEEK, R. Smith, Marx and After: Ten Essays in the Development of Economic Thought. Chapman and Hall, 1977.

MONZANI, L. R. Desejo e prazer na idade moderna. Campinas, SP: Editora da UNICAMP, 1995.

MULLER, R. Les Stoiciens. Paris: Vrin, 2006.

OAKE, R. Montesquieu's Analysis of Roman History. In.: Journal of the History of Ideas, Vol. 16, No. 1 (Jan., 1955), pp. 44-59.

OZ-SALZBERGER, F. Translating the Enlightenment: Scottish Civic Discourse in Eighteenth-Century Germany. New York: Oxford University Press, 2002. Adam Ferguson's Histories in Germany: English Liberty, Scottish Vigour and German Rigour. British and German Historiography 17501950: Traditions, Perceptions and Transfers. Peter Wende and Benedikt Stuchtey (Eds.) Oxford: Oxford University Press, 2000.

PELTONEN, M. (ed.). The Cambridge Companion to Bacon. Cambridge: Cambridge University Press, 1996.

PHILLIPSON, N. The Scottish Enlightenment. In.: The Enlightenment in National Context, org. Roy Porter e Mikulás Teich. Cambridge: Cambridge University Press, 1981.

David Hume, The Philosopher as Historian. London: Yale

University Press, 1989.

PIMENTA, P. P. Refinamento e Civilização, ou como se colocar à altura do seu tempo.

In.: A Imaginação Crítica: Hume no Século das Luzes. Rio de Janeiro: Beco do Azougue, 2013. 
A trama da natureza. São Paulo: Editora Unesp, 2018.

POCOCK, J. G. A. The Machiavellian Moment: Florentine Political Thought and the Atlantic Republican Tradition. Princenton, NJ: Princenton University Press, 1975.

Barbarism and Religion. Cambridge: Cambridge University Press, 1999, volume two: Narratives of civil government.

RADFORD, R. T. Cicero: a study in the origins of Republican Philosophy. New York: Rodopi, 2002.

RAPHAEL, D. D. The Impartial Spectator. Oxford: Oxford University Press, 1975.

ROBERTSON, J. The Scottish Enlightenment and the Militia Issue. Edinburgh: John Donald Publishers LTD., 1985.

SHER, R. Church and University in the Scottish Enlightenment: The Moderate Literati of Edinburgh. Edinburgh: Edinburgh University Press, 1985.

SIMÓN, I. W. Sociedad Civil y Virtud Cívica em Adam Ferguson. Madrid: Centro de Estudios Políticos y Constitucionales, 2006.

Teoría Social y Política de la Ilustración Escocesa. Madrid: Plaza y

Valdés Editores, 2007.

SMITH, C. Adam Ferguson and the Idea of Civil Society. Edinburgh: Edinburgh University Press, 2019.

STEWART, D. The works of Dugald Stewart, in seven volumes. Cambridge: published by Milliard and Brown, 1829, vol. VI.

TEGGART, F. J., The Idea of Progress: A Collection of Readings, Revised Edition, G.

H. Hildebrand (ed.), Berkeley, CA: University of California Press, 1949.

TREVOR-ROPER, H. The Scottish Enlightenment. In.: Studies on Voltaire and the Eighteenth Century, 58, 1967, pp. 1635-58.

WASZEK, N. Man's Social Nature: A Topic of the Scottish Enlightenment in its Historical Setting. Francfort: Peter Lang, 1986.

The Scottish Enlightenment and Hegel's Account of Civil Society.

Drodrecht: Kluwer academic, 1988.

. L’Écosse des Lumières. Paris: Presses Universitaires de France, 2003.

Progrès et Déclin chez Ferguson: "a long, cool look at both sides of the medal of modern civilization" (Duncan Forbes). In.: Autour de l"Essay on The History of Civil Society. Sous la direction de Clotilde Prunier. Paris: Press Universitaires de Paris Ouest, 2014.

WOOD, P. The natural history of man in the Scottish Enlightenment. In.: History of Science, 27, pp. 89-123, 1989. 
The Science of Man. In.: Cultures of Natural History. Ed. By N. Jardine, J. A. Secord and E. C. Spary. Cambridge: Cambridge University Press, 1996.

WINCH, D. Adam Smith's Politics: an Essay in Historiographic Revision. New York: Cambridge University Press, 1978. 